\title{
Economie mondialisée et identités de genre
}

\author{
Textes réunis par \\ Fenneke Reysoo
}

Les colloques genre de l'IUED: Collection Yvonne Preiswerk
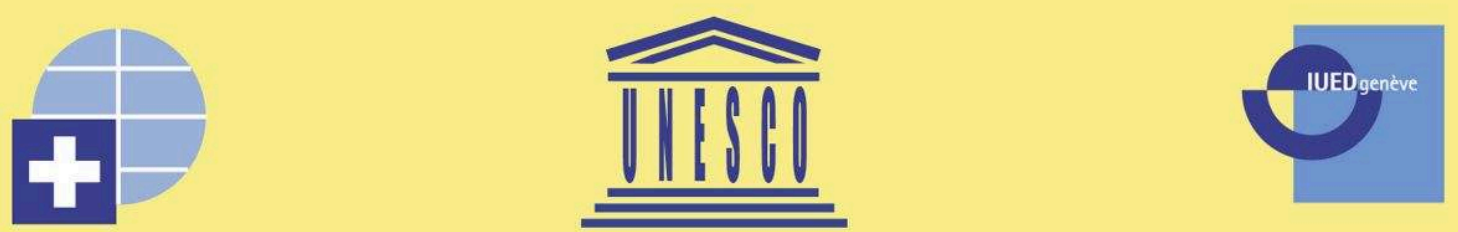

Commission suisse pour l'Unesco, Berne

DDC, Direction du développement et de la coopération

Département fédéral des affaires étrangères, Berne

IUED, Institut universitaire d'études du développement, Genève

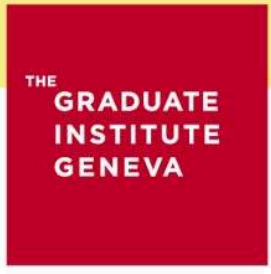

$-$

INSTITUT DE HAUTES

ÉTUDES INTERNATIONALES

ET DU DÉVELOPPEMENT

GRADUATE INSTITUTE

OF INTERNATIONAL AND

DEVELOPMENT STUDIES

NOUVELLE ÉDITION

\section{GENRE ET DÉVELOPPEMENT | RENCONTRES}




\section{Graduate Institute Publications}

\section{GENEVA}

GRADUATE

INSTITUTE

\section{Économie mondialisée et identités de genre}

\section{Fenneke Reysoo (dir.)}

DOI : 10.4000/books.iheid.6161

Éditeur : Graduate Institute Publications

Lieu d'édition : Genève

Année d'édition : 2002

Date de mise en ligne : 5 juillet 2016

Collection : Genre et développement. Rencontres

EAN électronique : 9782940503780

\section{OpenEdition}

\section{Books}

https://books.openedition.org

\section{Édition imprimée}

EAN (Édition imprimée) : 9782882470485

Nombre de pages : 228

\section{Référence électronique}

REYSOO, Fenneke (dir.). Économie mondialisée et identités de genre. Nouvelle édition [en ligne]. Genève Graduate Institute Publications, 2002 (généré le 16 février 2023). Disponible sur Internet : <http:// books.openedition.org/iheid/6161 >. ISBN : 9782940503780. DOI : https://doi.org/10.4000/ books.iheid.6161. 


\section{RÉSUMÉS}

Avant même que le terme "mondialisation " fût introduit dans les débats politiques, des recherches genre se penchaient déjà sur les entreprises transnationales et la nouvelle division internationale du travail. Cet ouvrage fait le point sur les dimensions économiques, politiques et culturelles du processus de mondialisation, essentiellement à travers leurs effets sur les rapports de genre. L'ouvrage montre que les processus de la mondialisation sont étroitement liés à la vie quotidienne des femmes dans les quatre coins du monde. Elles sont contraintes à faire des choix qui affectent leurs sécurités existantes. Elles ouvrent néanmoins de nouvelles voies et de nouveaux défis qui peuvent - dans certains cas - bousculer les rapports de genre. 


\section{Economie mondialisée et identités de genre}

Textes réunis par Fenneke Reysoo

DDC/Unesco/IUED, Genève, 2002, 221 p.

\section{Table des matières}

Gerdien Steenbeek, Annelou Ypeij et Fenneke Reysoo

Genre et mondialisation : exploration d'un débat.

Economie mondialisée, développement durable et égalité de genre : enjeux des politiques de développement

Shahra Razavi

Globalization, Employment and Women's Rights

Bene E. Madunagu

Women's Agency for Gender Justice : Experiences of African Women.

\section{Théories et pratiques}

Silvia Federici

Women, Reproduction and Globalization

Fatmata Lovetta Sesay

Alternatives for Sustainable Development and Gender Equality : A Case Study from Sierra Leone

Genoveva Tisheva

Some Aspects of the Impact of Globalization on Gender Issues in Bulgaria

Isabel Rauber

Mujeres piqueteras : el caso de Argentina.

\section{Globalité et localité}

Alexis Kabore

Pas d'avion, pas d'argent. Des femmes rurales face aux risques de la mondialisation (Burkina Faso)

Marie-Pierre Essimi Nguina

Globalité et localités : le cas de sa'a au Cameroun

Antonio Girardi

Division sexuelle du travail rémunéré et domestique en Suisse, dans un contexte d'économie mondialisée. 
Dilemmes des processus de mondialisation économique dans la mise en ouvre des politiques de développement durable et de l'égalité de genre

Fenneke Reysoo

Résumé de la table ronde : «Economie mondialisée et identités de genre » (version française)

« Global Economy and Gender Identities » : A Round Table Debate (English version)

\section{Synthèse}

Wendy Harcourt

Gender an Economic Globalization : Reflections on the iuéd Geneva Colloquium

Annexe

Bulgarian Gender Research Foundation (BGRF) 


\section{GENRE ET MONDIALISATION: EXPLORATION D'UN DÉBAT ${ }^{1}$}

\section{Gerdien Steenbeek, Annelou Ypeij et Fenneke Reysoo ${ }^{2}$}

Aucun sujet n'est autant à la une du débat politique et économique actuel que la question de la mondialisation. Mode ou pas, la réalité de la mondialisation semble incontournable. Une réalité qui se caractérise par une extension et une densification des relations à grande distance. Les gens sont de plus en plus intégrés dans des chaînes d'interdépendance mondiale. Des flux internationaux de personnes, de cultures, de symboles, d'images, de biens, d'argent et d'information s'intensifient. La montée des nouvelles technologies de l'information et de la communication, la libéralisation de l'économie mondiale, l'internationalisation du marché du travail, l'augmentation des flux

1 Cet article est également paru dans Christine Verschuur (dir.) avec Fenneke Reysoo, Genre, mondialisation et pauvreté, Cahiers Genre et Développement, $\mathrm{n}^{\circ}$ 3, Genève: iuéd-efi; Paris: L'Harmattan, 2002, 255 p., pp. 23-33.

2 Gerdien Steenbeek, chargée d'enseignement dans le département d'anthropologie sociale à l'Université d'Utrecht aux Pays-Bas. Annelou Ypeij, chercheure au «Rotterdam Institute of Policy Research in the Social Sciences» (Université d'Erasme à Rotterdam). Fenneke Reysoo, chargée de cours à l'iuéd pour les questions «genre et développement » et responsable du colloque genre. Egalement enseignante-chercheure à l'Université de Nimègue aux Pays-Bas. 
migratoires, l'influence grandissante de la Banque mondiale et du FMI sur les économies des pays en voie de développement et des pays en transition, la venue des Etats supranationaux, l'importance croissante des grandes villes comme centres de contrôle des mouvements de capitaux et l'internationalisation des mouvements sociaux de base constituent autant d'exemples des processus de changement que l'on désigne par le terme de «mondialisation».

Cette mondialisation est en train de devenir un concept fourre-tout auquel politiciens, technocrates, bureaucrates, journalistes et intellectuels n'hésitent pas à recourir afin d'expliquer les changements survenus lors des dernières décennies. Kalb (2000) attire l'attention sur la complexité et le caractère multidimensionnel du terme «mondialisation». Dans la réalité, il s'agit d'un processus qui implique une plus grande intégration des gens et des lieux géographiques dans les échanges de capitaux, de biens, d'informations, d'idées et de personnes. De plus, c'est une problématique socio-anthropologique que l'on étudie et sur laquelle on débat. C'est un discours politique et économique, une narration, qui justifie le principe du libre marché du néolibéralisme, le pouvoir croissant des entreprises transnationales et l'importance décroissante des Etats-nations (Kalb 2000 : 3). Le monde idéal présenté par ce discours est un monde sans frontières, où tous les pays sont intégrés dans une économie et où la gouvernance globale a remplacé les Etats-nations (cf. Ohmae 1990).

Les fruits de la mondialisation se répartissent cependant d'une manière plus inégale que le discours néolibéral ne veut bien nous le faire croire. Le processus de mondialisation profite avant tout à un certain nombre de groupes dans le monde occidental. Selon Afshar et Barrientos (1999), les femmes - où qu'elles soient - ne tirent jamais le gros lot: «The almost exclusively male elite who head the transnational companies and the national and international bureaucrats who facilitate the process have profited most, and have enthusiastically welcomed the new global order» (Afshar et Barrientos 1999 : 2). 
Différents auteurs argumentent que le processus de mondialisation s'accompagne d'inégalités grandissantes, aussi bien à l'intérieur des pays qu'entre les pays, mais aussi entre femmes et hommes (Afshar et Barrientos 1999; Dibaja 1997, Sklair 1994). Plus particulièrement pour les pays en voie de développement, les effets du processus de mondialisation sont multiples et opposés. Il s'accompagne d'inclusion aussi bien que d'exclusion, d'inégalité et de fragmentation. Le débat scientifique ne peut pas ignorer le revers de la médaille de la mondialisation. Le vécu quotidien des femmes, des minorités ethniques et religieuses, et des groupes marginalisés est d'une importance cruciale pour comprendre tous les aspects de la mondialisation. Du fait que les femmes sont de plus en plus intégrées dans les processus de production et de consommation mondiaux, poursuivent Afshar et Barrientos (1999 : 1-3), la mondialisation a un impact considérable sur la vie quotidienne des femmes, jusque dans les coins les plus reculés du monde. Cela nous incite à examiner la relation entre genre et mondialisation. Les femmes n'en sont-elles que les victimes? Comment les processus politiques et économiques des deux dernières décennies structurent-ils la vie quotidienne des femmes, et comment le "genre» influence-t-il le processus de mondialisation? Dans cet article nous distinguerons les dimensions économiques, politiques et culturelles de la mondialisation - qui s'influencent mutuellement - et nous nous pencherons en particulier sur la position des femmes dans les pays du Sud. Comme il existe peu de publications qui examinent de manière systématique les rapports entre genre et mondialisation dans ces différentes dimensions, nous nous référerons beaucoup à un nombre limité d'auteurs (Afshar et Barrientos 1999, Laurie et al. 1999, chapitre 2).

\section{LA DIMENSION ÉCONOMIQUE}

Dans le but de maitriser la crise de la dette et de stimuler la croissance économique, le FMI et la Banque mondiale ont imposé leurs programmes d'ajustement structurel aux pays en voie de développement. Ces programmes d'ajustement, inspirés d'un modèle néolibé- 
ral, sont considérés comme les signes visibles des effets de la mondialisation dans le Sud. Les stratégies nationales d'éradication de la pauvreté ainsi que la promotion du développement économique par l'intervention de l'Etat et les substitutions des importations ont été remplacées par la libéralisation de l'économie, qui oblige les pays en voie de développement à suivre un modèle politique et économique qui favorise leur intégration dans l'économie mondiale (Afshar et Barrientos 1999: 3; Afshar et Dennis 1992; Rajput et Lata Swarup 1994). Cette stratégie d'une économie ouverte et d'un marché libre doit entre autres attirer les entreprises transnationales.

Avant même que le terme de «mondialisation» fût introduit, des recherches genre se penchaient déjà sur les entreprises transnationales et la nouvelle division internationale du travail. La dérégulation des marchés du travail, la fragmentation des processus de production, la désindustrialisation dans le monde occidental ont induit une demande exponentielle de main-d'œuvre féminine dans les pays du Sud. Tout d'abord, les entreprises transnationales s'installèrent dans les zones franches, comme la région des maquiladores dans le nord du Mexique, limitrophe des Etats-Unis, ou la investment pro motion zone au Sri Lanka (Fernández-Kelly 1983; Goonatilake et Goonesekere 1988). Les modalités des contrats et les conditions de travail dans ces zones ne connaissent qu'un minimum de régulation. A cause de toutes sortes de qualités féminines (prétendues ou vraies) légitimant les bas salaires, les entreprises employèrent surtout des femmes jeunes et célibataires (Elson et Pearson 1981). De nos jours, les entreprises transnationales ont implanté leurs usines également en dehors de ces zones économiques spéciales, elles concernent aussi l'agroalimentaire et recrutent des femmes de tous âges. De plus, le système de leasing crée un nombre croissant de travailleuses à domicile (ouvrières indépendantes et micro-entrepreneuses travaillant dans le secteur informel urbain) qui sont intégrées dans l'économie mondiale. Les industries nationales se voient confrontées à la politique économique des frontières ouvertes et sont obligées d'entrer en concurrence sur le marché mondial. Comme l'explique Stobbe (2000), la meilleure façon de réussir dans ce cas est l'importation 
d'un nouveau système de production et de gestion, connu sous le nom de lean production. Cette restructuration de l'industrie a des conséquences importantes pour les employé-e-s (Afshar et Barrientos 1999; Arizpe et Aranda 1986; Benería et Roldán 1987; Heyzer 1988; Mies 1982; Nash et Fernández-Kelly 1983; Roldán 1993 ; Safa 1981; Stobbe 2000 ; Ypeij 2000).

Que signifient ces développements pour la vie quotidienne des femmes dans les pays en voie de développement? Selon Afshar et Barrientos, la mondialisation représente une possibilité à la fois d'empowerment et de disempowerment des femmes (1999: 5; cf. Ward 1990). Le démantèlement des services sociaux, suite aux programmes d'ajustement structurel, est pallié par les femmes. Elles sont obligées d'intensifier leurs tâches domestiques ainsi que leur participation dans les organisations de base et de quartier. Comme les marchés locaux du travail sont de plus en plus imbriqués dans l'économie mondiale, on assiste à de nouvelles opportunités de travail, mais il s'agit essentiellement de travaux mal payés et flexibles. Les ménages pauvres ne peuvent plus survivre avec un seul salaire, et les femmes entrent massivement sur le marché du travail, surtout comme ouvrières dans l'industrie. En même temps, les hommes résistent fortement face à cette inversion de la division sexuelle du travail et ne s'adonnent pas aux tâches domestiques. Enfin, les processus de migration de travail (nationaux et internationaux) induisent le départ des hommes de leurs foyers et l'augmentation du nombre des ménages avec une femme comme chef. Ces effets négatifs de la mondialisation sont conceptualisés par l'expression «féminisation de la pauvreté»; le poids de la pauvreté repose avant tout sur les épaules des femmes (pour une critique de ce point de vue, voir Chant 1997; Davids et Van Driel 2001; Van Driel 1994; Marchand 1996; Marcoux 1997; Mencher et Okongwu 1993; Sen 1997). Cependant, celles-ci ne sont pas seulement représentées comme les victimes dans le débat sur la mondialisation. Paradoxalement, elles sont aussi considérées comme des instruments qui peuvent aider à trouver des solutions aux problèmes causés par la mondialisation (Davids et Van Driel 2001). 
L'ensemble de ces développements fait que les femmes inaugurent des stratégies de survie dans lesquelles elles combinent leur participation dans des associations de base, la génération de revenus multiples et les tâches domestiques et reproductives. La pression sur leur budget temps s'accroît (Afshar et Barrientos 1999: 5; Benería et Feldman 1992; Moser 1992; Standing 1989).

Parallèlement, l'arrivée massive des femmes sur le marché du travail industriel dans les pays en voie de développement leur offre de nouvelles opportunités. Elles obtiennent la possibilité de générer un revenu propre, ce qui pourrait accroître leur autonomie. Les ménages sont de plus en plus souvent dépendants des revenus des femmes, ce qui augmente le statut social et le pouvoir de négociation de ces dernières face aux autres membres de la famille (Afshar 1998; Kabeer 1994). Au fur et à mesure que les femmes sont massivement impliquées dans le processus de production mondial, leur potentiel d'organisation de nouvelles formes de résistance augmente. Cela est en relation avec leur travail dans les organisations de base, où elles créent des formes de solidarité, d'appui et de collaboration nouvelles. Cette tendance peut être renforcée par les contacts avec les ONG qui les épaulent dans le but de s'intégrer dans les réseaux de solidarité internationaux. La dimension politique de la mondialisation a fait que la création et l'influence des ONG ont pris un grand essor.

\section{LA DIMENSION POLITIQUE}

L'importance croissante des ONG a un lien direct avec le rôle changeant des Etats-nations. Au fur et à mesure que la mondialisation avance, les Etats-nations semblent disparaître. D'un côté, le pouvoir des Etats-nations est remplacé par celui des entreprises transnationales; les régulations étatiques sont subordonnées à la dynamique de l'économie mondiale et du marché libre. De l'autre côté, les gouvernements nationaux se voient confrontés aux problèmes sociaux et économiques ancrés dans les processus mondiaux et dont l'im- 
pact dépasse la gouvernance locale et nationale; il suffit d'évoquer la problématique des réfugié-e-s, les organisations criminelles internationales, l'épidémie du sida et la pollution environnementale. La coopération entre Etats-nations devient de plus en plus importante, comme la participation dans les organisations transnationales et la création d'Etats supranationaux telle l'Union européenne. Les organisations transnationales exercent une influence grandissante sur la gouvernance nationale. Les Nations unies, par exemple, exercent une pression spécifique dans le domaine des droits humains, la bonne gouvernance et la démocratie (Laurie et al. 1999; Leftwich 1993). Le FMI et la Banque mondiale donnent un appui économique à condition d'accepter la recette néolibérale de l'économie ouverte, du marché libre et de la privatisation des services sociaux.

L'avancement de la mondialisation signifie que les Etats-nations sinternationalisent en même temps qu'ils se referment sur eux-mêmes. Les organisations de base et les ONG se développent dans le vide créé par le désistement de l'Etat. Elles ont la possibilité d'autogouvernance et de processus décisionnels démocratiques. Elles sont des sorties de secours (safety net) pour la protection sociale de l'individu, et un tremplin pour accéder aux réseaux internationaux. Elles ont des contacts avec les bailleurs de fonds et des organisations de coopération technique, elles canalisent des capitaux et des biens internationaux vers les pauvres (Afshar et Barrientos 1999; Castells 1997; Laurie et al. 1999; Escobar et Alvarez 1992). Ce sont surtout les femmes qui s'activent dans cette couche diffuse et intermédiaire de la gestion politique et des organisations de base. Elles y militent pour les droits humains et les droits des femmes, pour les questions environnementales, la paix, les infrastructures collectives, le logement, etc. Les ONG les soutiennent avec des moyens, du savoir et de l'expérience. Une stimulation pour réaliser une gouvernance démocratique passe ainsi du niveau local au niveau régional, puis national et international. On parle de nouveaux mouvements sociaux, qui appliquent des modes de fonctionnement démocratiques et dont les structures informelles contrastent avec les hiérarchies de la scène politique formelle (Afshar et Barrientos 1999; Laurie et al. 1999). 
Devons-nous nous réjouir de la montée de ces nouveaux mouvements sociaux? Leurs résultats pour les femmes sont multiples et contrastés (Afshar et Barrientos 1999). Les ONG et les organisations de base entraînent une participation politique croissante des femmes, ce qui signifie un empowerment potentiel. L'articulation entre les organisations de base et les réseaux transnationaux suite à la mondialisation permet une plus grande communication entre les femmes au niveau mondial. Un exemple type est l'internationalisation du mouvement de la femme. Les organisations de femmes du Sud et du Nord ont intensifié leurs réseaux dans les années 1980 et 1990, ce qui a débouché sur l'intégration de la politique du genre dans l'agenda des Nations unies et, après Mexico (1975), sur la tenue des conférences de Copenhague (1980), de Nairobi (1985) et de Beijing (1995) (Laurie et al. 1999). L'étude de Prügl (1999) donne un autre exemple du caractère transnational des mouvements sociaux. Elle examine comment le lobby international du réseau mondial des syndicats de femmes a abouti en 1996 à la Convention de l'OIT sur le travail à domicile. Un troisième exemple est fourni par l'étude de Radcliffe, qui analyse la résistance contre la guerre sur la frontière entre le Pérou et l'Equateur en 1995. Les groupes $d^{\prime}$ Indiens et les groupes de femmes issus des deux pays ont fait connaître leur résistance grâce aux réseaux de solidarité internationaux, en utilisant les technologies du courrier électronique et du fax (Radcliffe 1998; Laurie et al. 1999). Pensez également aux e-mails que nous recevons régulièrement des groupes de femmes internationaux qui font appel au soutien et à la protestation. Qu'est-ce que cela signifie pour le mouvement de la femme? Cela crée-t-il une sororité ou ne s'agit-il que d'une réalité virtuelle? Est-ce que l'on échange des expériences, et cela produit-il de la connaissance? Quelles sont les possibilités et quels sont les dangers de la mondialisation de la connaissance féministe?

La participation croissante des femmes dans les organisations de base ne favorise pas seulement les opportunités. Cette participation fait pression sur le nombre d'activités des femmes. A côté de leurs activités domestiques et reproductives, et leur travail rémunéré, elles 
portent des responsabilités politiques en tant que community mem bers. Les gouvernements nationaux aussi bien que les ONG et les organisations internationales font de plus en plus souvent appel à elles. Est-ce le revers de la médaille de la reconnaissance de leur rôle dans les organisations de base qu'on les utilise comme instruments pour résoudre les problèmes sociopolitiques (Davids et Van Driel, 2001)?

\section{LA DIMENSION CULTURELLE}

La mondialisation est souvent conçue - d'une manière explicite ou implicite - comme une articulation économique et macropolitique. Elle est pourtant un processus non seulement économique et politique, mais également culturel. A une époque où la culture se dissocie des frontières territoriales, la signification des identités et des différences culturelles suscite un intérêt croissant, que reflètent les projets de recherche en sciences sociales actuellement en cours. On peut distinguer différentes visions théoriques à cet égard. La perspective néolibérale et moderniste conçoit que la dimension culturelle de la mondialisation n'est rien d'autre qu'une homogénéisation continue selon un modèle occidental. L'accent est mis sur l'impérialisme culturel et l'occidentalisation, représentés par Coca-Cola et les Big Macs. On nous prédit un monde où les différences culturelles locales disparaissent pour céder la place à des valeurs, normes et pratiques à l'occidentale, univoques et uniformes. La mondialisation amènerait-elle avec elle une homogénéisation de la culture? Si oui, s'agit-il d'une américanisation, d'une macdonaldisation, avec des formes locales de production, de distribution et de consommation de plus en plus intensives en capitaux (Ritzer 1993; Davids et van Driel 2001 ; Kalb et van der Land 2000 : 278) ?

A l'opposé, on trouve la vision selon laquelle la mondialisation induit des processus de protection et de sauvegarde des traditions locales. La mondialisation mènerait à des identités culturelles hétérogènes et diverses. Appadurai soutient que les messages transmis 
vers le niveau local par les processus de mondialisation sont interprétés de diverses manières. Plus d'une fois, ils sont assimilés comme de nouveaux éléments culturels, et intégrés dans des pratiques existantes. Appadurai affirme en conséquence que la mondialisation est la «production mondiale de la différence» (Appadurai 1990; Appadurai 1996 : 199; Warde 2000; Davids et van Driel 2001 ; Verstraete 2000 ; Meyer et Geschiere 1999).

La troisième vision, en relation avec la précédente, est défendue par les auteurs qui mettent l'accent sur un développement qui va simultanément dans les deux sens, prônant que les processus de mondialisation et de localisation sont étroitement imbriqués (Kloos 2000). On parle même de processus de «glocalisation». Hannerz (1992, 1996) pense que les processus transnationaux créent des cultures hybrides et produisent des nouvelles localités et identités. En plus du terme «hybridation», on utilise parfois le mot "créolisation» pour désigner ce phénomène. Des groupes transnationaux qui forment une unité culturelle et identitaire tout en vivant éparpillés sur le globe, les prétendues diasporas, contribuent à la création de ces cultures hybrides. Les significations et valeurs ethniques spécifiques sont transférées et transformées vers de nouvelles localités et dans de nouveaux contextes, et induisent ainsi de nouvelles formes culturelles (Hannerz 1992, 1996; Kloos 2000 ; Laurie et al. 1999).

Au sein du débat sur la dimension culturelle de la mondialisation, l'ethnicité est souvent présentée comme la caractéristique la plus importante de l'identité. La mondialisation est cependant un phénomène complexe où les différences raciales, ethniques, religieuses, de classe, de genre et de sexualité se rencontrent et se redéfinissent (Verstraete 2000). Les processus culturels de la mondialisation menacent-ils les relations de genre et leurs significations? Va-t-on vers une image universelle de la femme, comme le présuppose la vision théorique de l'homogénéisation? Ou bien la mondialisation produira-t-elle de plus grandes différences dans les positions et les rapports de pouvoir entre femmes et hommes? Certaines études confirment que les migrations transnationales et la venue de diaspo- 
ras renforcent les rôles traditionnels des femmes (Laurie et al. 1999). La mondialisation est parfois le détonateur de mouvements antimodernisation au niveau local qui glorifient les valeurs traditionnelles. Les identifications locales, l'ethnicité, les valeurs traditionnelles et les sentiments nationalistes seront mis en avant dans un tel processus.

Ce sont parfois justement les femmes, en tant que gardiennes de la tradition et des valeurs morales, qui s'organisent pour défendre les conceptions traditionnelles de la féminité et revendiquent une identification avec la sphère domestique (Afshar et Barrientos 1999: 1011; Phalkey 1999). Parallèlement, la mondialisation peut donner de nouveaux signifiants aux relations et identités de genre. Bhachu décrit comment les femmes sikhs qui vivent en Angleterre ont transformé la signification de la dot et le système douaire. Dans le contexte britannique, la dot est un atout pour les femmes car elle leur assure une indépendance financière (Bhachu 1993; Laurie et al. 1999). Bien que les ménages avec une femme comme chef - très souvent associés à la dimension économique de la mondialisation et à la féminisation de la pauvreté - soient considérés comme problématiques, on peut se demander si les femmes sont mieux loties dans les ménages avec un homme à la tête (Davids et van Driel 2001, Chant 1997). Comme la matrifocalité dans les Caraibes nous le montre, la maternité single ne signifie pas uniquement un risque de pauvreté, mais également le vécu d'autonomie et de pouvoir de décision sur sa propre vie (Wekker 1994).

Il est clair que le débat sur les dimensions économiques, politiques et culturelles du processus de la mondialisation ne propose pas de réponses simples quant à leurs effets sur les rapports de genre. Les positions des femmes dans ces processus sont multiples et opposées. Les femmes sont inclues et exclues (Stobbe 2000, Afshar et Barrientos 1999). Elles ont de nouvelles opportunités par l'internationalisation des marchés du travail, les flux migratoires, les échanges d'informations et les mouvements sociaux internationaux; en même temps, cela leur confère plus de responsabilités, de travail 
et d'obligations et une pression accrue sur leur budget temps. Les changements des significations de féminité et de masculinité et des rapports de genre peuvent aller dans des directions opposées: empo werment et disempowerment, autonomie et dépendance, innovations et revivification des moralités traditionnelles. Du fait que les processus de mondialisation sont étroitement liés à la vie quotidienne des femmes dans les quatre coins du monde, elles (et nous avec elles) sont de plus en plus contraintes à faire des choix qui affectent les sécurités existantes, mais ouvrent la voie vers de nouvelles possibilités et de nouveaux défis à relever (Afshar et Barrientos 1999).

\section{Bibliographie}

Afshar, H. (1998) (ed.) Women and Empowerment: The Politics of Development, Basingstoke: Macmillan.

Afshar, Haleh et Stephanie Barrientos (1999) «Introduction: Women, Globalization and Fragmentation» in: Haleh Afshar et Stephanie Barrientos (ed.) Women, Globalization and Fragmentation in the Developing World, Londres: Macmillan Press.

Afshar Haleh et C. Dennis (ed.) (1992) Women and Adjustment Policies in The Third World, Basingstoke: Macmillan.

Appadurai, Arjun (1990) «Disjuncture and Difference in the Global Cultural Economy», Theory Culture and Society, 7: 23, pp. 295-310.

-, (1996) Modernity at Large: Cultural Dimensions of Globalization, Minneapolis, University of Minnesota Press.

Arizpe, Lourdes et Josefina Aranda (1986) «Women Workers in the Strawberry Agribusiness in Mexico» in: Eleanor B. Leacock et Helen I. Safa (ed.) Women's Work, Development and the Division of Labor by Gender, Massachusetts: Bergin and Garvey.

Benería, Lourdes et S. Feldman (1992) (ed.) Unequal Burden, Economic Crises, Persistent Poverty, and Women's Work, Boulder: Westview Press.

Benería, Lourdes et Martha Roldán (1987) The Crossroads of Class and Gender, Industrial Subcontracting, and Households Dynamics in Mexico-City, Chicago : The University of Chicago Press. 
Bhachu, P. (1993) «Identities Constructed and Reconstructed: Representations of Asian Women in Britain» in: G. Buijs (ed.) Migrant Women: Crossing Boundaries and Changing Identities, Oxford: Berg.

Castells, Manuel (1997) The Power of Identity, Londres: Blackwell.

Chant, Sylvia (1997) Women Headed Households: Diversity and Dynamics in the Developing World, Basingstoke: Macmillan.

Davids, Tine et Francien van Driel (2001) «Globalization and Gender: Beyond Dichotomies» in: F. Schuurman Globalization and Development Studies, Challenges for the 21st Century, Londres: Sage.

Dibaja, Z. (1997) «Globalization: the Last Sky» The European Journal of Development Research 9 (1), juin.

Driel, Francien van (1994) Poor and Powerful: Female-headed Household and Unmarried Motherhood in Botswana, Nijmegen Studies 16, Saarbrücken: Verlag für Entwicklungspolitiek Breitenbach GmbH.

Elson, Diane et Ruth Pearson (1981) «The Subordination of Women and the Internationalization of Factory Production» in: Kate Young, Carl Wolkowitz et Roslyn McCullagh (ed.) Of Marriage and the Market, Women's Subordination Internationally and Its Lessons, Londres, New York: Routledge.

Escobar, A. et S. Alvarez (ed.) (1992) The Making of Social Movements in Latin America. Identity, Strategy and Democracy, Boulder: Westview Press.

Fernández-Kelly, María Patricia (1983) For We Are Sold, I and My People, Women and Industry in Mexico's Frontier, Albany: State University of New York Press.

Goonatilake, Hema et Savitir Goonesekere (1988) «Industrialization and Women Workers in Sri Lanka: Working Conditions Inside and Outside the Investment Promotion Zone» in: Noeleen Heyzer (ed.) Daughters in Industry. Work Skills and Consciousness of Women Workers in Asia, Kuala Lumpur: Asian and Pacific Development Centre.

Hannerz, Ulf (1992) Cultural Complexity, New York: Columbia University Press.

-, (1996) Transnational Connextions: Culture, People, Places, Londres: Routledge.

Heyzer, Noeleen (ed.) (1988) Daughters in Industry. Work Skills and Consciousness of Women Workers in Asia, Kuala Lumpur: Asian and Pacific Development Centre.

Kabeer, Naila (1994) Reversed Realities, Londres: Verso.

Kalb, Don (2000) «Localizing Flows: Power, Paths, Institutions and Networks» in: Don Kalb, Marco van der Land, Richard Staring, Bart van Steenbergen, Nico Wilterdink (ed.) The Ends of Globalization. Bringing Society Back In, Lanham: Rowman et Littlefield. 
Kalb, Don et Marco van der Land (2000) «Beyond the Mosaic: Questioning Cultural Identity in a Globalizing Age» in: Don Kalb, Marco van der Land, Richard Staring, Bart van Steenbergen, Nico Wilterdink (ed.) The Ends of Globalization. Bringing Society Back In, Lanham: Rowman et Littlefield.

Kloos, Peter (2000) «The Dialectics of Globalization and Localization» in: Don Kalb, Marco van der Land, Richard Staring, Bart van Steenbergen, Nico Wilterdink (ed.) The Ends of Globalization. Bringing Society Back In, Lanham: Rowman et Littlefield.

Laurie, Nina, Claire Dwyer, Sarah Halloway, Smithe Fiona (1999) Geographies of New Femininities, Harlow: Longman.

Leftwich, A. (1993) «Governance, Democracy and Development in the Third World», Third World Quarterly, 15: 3.

Marchand, Marianne H. (1996) «Reconceptualising 'Gender and Development' in an Era of 'Globalisation'», Millennium, 32: 3, pp. 577-603.

Marcoux, Alain (1997) The Feminisation of Poverty: Facts, Hypothese, and the Art of Advocacy, FAO Population Programme Service, <www.undp.org/popin/fao/ womnpoor. htm>.

Mencher, Joan P. et Anne Okongwu (1993) Were Did All the Men Go? Female headed/Female Supported Households in Cross-Cultural Perspective, Boulder Colorado: Westview Press.

Meyer, Birgit et Peter Geschiere (1999) Globalization and Identity. Dialectics of Flow and Closure.

Mies, Maria (1982) The Lacemakers of Narsapur: Indian Housewives Produce for the Worldmarket, Londres: Zed Press.

Moser, Caroline (1992) «Adjustment from Below: Low Income Women, Time and the Triple Role in Guayaqui, Ecuador» in: Haleh Afshar et C. Dennis (ed.) Women and Adjustment Policies in The Third World, Basingstoke: Macmillan.

Nash, June et María Patricia Fernández-Kelly (1983) Women, Men and the International Division of Labor, Albany: State University of New York Press.

Ohmae, K. (1990) The Borderless World, Power and Strategy in the Interlinked Economy, Londres: Fontana.

Phalkey, Jahnavi (1999) «Right-wing Mobilization of Women in India: Hindutva's Willing Performers» in: Haleh Afshar et Stephanie Barrientos (red.) Women, Globalization and Fragmentation in the Developing World, Londres: Macmillan Press.

Prügl, Elisabeth (1999) The Global Construction of Gender, Home-Based Work in the Political Economy of the 20th Century, New York: Columbia. 
Radcliffe, S. (1998) «Frontiers and Popular Nationhood: Geographies of Identity in the 1995 Ecuador-Peru Border Dispute», Political Geography, 17, pp. 273-293.

Rajput, Pam et Hem Lata Swarup (red.) (1994) Women and Globalization, Reflections, Options and Strategies, New Delhi: Ashish Publishing House.

Ritzer, G. (1993) The McDonaldization of Society, Thousand Oaks (Calif.): Pine Forge.

Roldán, Martha (1993) «Industrial Restructuring, Deregulation and New JIT Labour Processes in Argentina; Towards a Gender-Aware Perspective», IDS Bulletin, $24: 2$, pp. 42-52.

Safa, Helen (1981) «Runaway Shops and Female Employment: The Search for Cheap Labour», Signs, $7: 2$, pp. 418-433.

Sen, Gita (1997) «Globalization, Justice and Equity: A Gender Perspective» Development, $40:$ 2, pp. 21-26.

Sklair, L. (1994) Capitalism and Development, Londres: Routledge.

Standing, G. (1989) «Global Feminization through Flexible Labor», World Development, 17: 7, pp. 1077-1095.

Stobbe, Lineke (2000) In- and Exclusion in the Argentine Auto Components Industry. A Study of Industrial Restructuring, Gender and Power, Saarbrücke: Verlag für Entwicklungspolitik.

Verstraete, Ginette (2000) «Etniciteit, gender, seksualiteit en de verbeelding van globalisering», Krisis, 1: 3, pp. 25-37.

Ward, K. (red.) (1990) Women workers and Global Restructuring, New York: ILR Press, Cornell University.

Warde, Alan (2000) «Eating Globally: Cultural Flows and the Spread of Ethnic Restaurants", in: Don Kalb, Marco van der Land, Richard Staring, Bart van Steenbergen, Nico Wilterdink (ed.) The Ends of Globalization. Bringing Society Back In, Lanham: Rowman et Littlefield.

Wekker, Gloria (1994) Ik ben een gouden munt, ik ga door vele handen, maar ver lies mijn waarde niet. Subjectiviteit en seksualiteit van Creoolse volksklasse vrou wen in Paramaribo, Amsterdam: Vita.

Ypeij, Annelou (2000) Producing against Poverty, Female and Male Micro-entrepre neurs in Lima, Peru, Amsterdam: Amsterdam University Press. 


\title{
GLOBALIZATION, EMPLOYMENT AND WOMEN'S RigHTS ${ }^{1}$
}

\begin{abstract}
Shahra Razavi ${ }^{2}$
I would like to open my presentation by first thanking our host, the Institut universitaire d'études du développemnt (iuéd), and the organizers of this colloquium, Professor Fenneke Reysoo and her colleagues, for inviting me. It is a pleasure to be here, to hear other speakers and to have the opportunity to discuss the issues that the organizers of this colloquium have put on the agenda - issues which are immensely important and affecting the lives of large numbers of people - women and men - across a wide range of societies in North and South, East and West.

With those words of introduction I will, if you permit, get straight into the presentation of my paper. First I would like to say that this presentation is based on a draft paper and is thus open to your comments and suggestions for revision.

The broad purpose of my presentation is to provide an understanding of how this thing that we call "globalization" since the early

1 Excerpts of this presentation have been translated into French and published in $\mathrm{Ch}$. Verschuur (dir.) with F. Reysoo, Genre, mondialisation et pauvreté, Cahiers Genre et Développement, no 3, Genève: iuéd-efi; Paris: L'Harmattan, 2002, 255 p., pp. 35-44.

2 Research co-ordinator at UNRISD (United Nations Research Institute on Social Development), Geneva.
\end{abstract}


1980s has impacted on the lives of women and men across a wide range of countries. More specifically, this paper intends to trace how the policies that we associate with "globalization" have impacted on women's access to employment and to their social rights. I think this issue is important for two main reasons.

First, even though the way in which stabilization and structural adjustment policies have impacted on poor women in the South has often been criticized, the debate on the impacts of trade liberalization on female employment has been far more upbeat. In fact, it is often argued that globalization (and trade liberalization in particular) has increased employment in developing countries as the center of manufacturing has shifted from the North to the South, and that within developing countries women have undoubtedly emerged as the unquestionable "winners". As one economist recently put it this has been the "saving grace of globalization". I think this argument is questionable and I will spend much of the time that I have to explain that it must be challenged.

Second, a related argument that I think needs to be looked at very carefully is about the connections between employment and social rights as far as women workers are concerned. This argument, which is very often implicit in the literature, says that as poor women in poor countries had few entitlements even prior to the neoliberal era - during the so-called "golden age" of capitalism when importsubstitution-industrialization strategies (or ISI) created jobs for a male "labour aristocracy" - it is meaningless to criticize globalization for creating jobs for women that have few social rights attached to them. Women had few rights anyway, so by definition no regression has affected them. Now that globalization has created "job for the girls" we should be content and stop complaining. Again, I think this argument is questionable and I will try to explain why.

But it is important that we first clarify what we mean by globalization. As we all know globalization has become a catch-all term for so many trends, that we need to be very careful not to use it as an 
excuse for sloppy thinking. For the purpose of my presentation I am concerned with "economic globalization", which I take to mean greater openness of economies to international trade and capital mobil ity, in other words, trade and financial liberalization.

I will now try to present the arguments that are more detailed in the paper I have prepared for this seminar - I will have to skip much of the details and hope that what I can present in the time that I have left will not sound too crude.

\section{PART ONE}

\section{The Facts about Globalization}

First I will try to explain some of the important facts about globalization which will help nuance some of the grand claims that are often made and question other assertions that are simply inaccurate. So what are these basic facts?

First, although over the past 20 years economies have been significantly opened up through massive reduction of tariffs, for example, from a historical point of view we know that the current phase of glob alization (i.e. the period from 1980 to present) is by no means unprece dented. Processes of international economic integration from the 1880s until the First World War probably surpassed many of the contemporary indices of globalization; interestingly the movement of labor across international borders was far more significant then than it is today.

Second, while globalists assume that there is an all-encompassing tendency in world trade, production and investment flows, these flows have actually remained very concentrated geographically - largely within the rich OECD countries and only in some developing countries, while most developing countries have not been integrated into the co-called "global" economy. 
Third, both globalization advocates and critics assume that national states have become powerless because of globalization. Here again I think we need to nuance and to take two important aspects in consideration. One is to distinguish between different kinds of state (obviously some states have more capacity than others); state capacities differ greatly across countries in how they are able to cope and/or exploit opportunities of international economic change. Second, there are also differences depending on what area of policy one is looking at. In the context of financial liberalization, the choices in macroeconomic policy have undoubtedly been significantly narrowed: deflationary and fiscally conservative policies have become the norm, and this clearly poses huge constraints on other policy areas. But when it comes to industrial and social policies, there is more room for maneuver, and in the case of social policies there remain significant diversities across regions and countries. The institutionalized welfare states, for example, have not by and large abandoned their welfare states as neoliberals assumed or hoped they would under the pressures generated by globalization. In other regions too, like East Asia, some countries (like South Korea and Taiwan) have made attempts to build up a more universalist welfare state - precisely in order to cope with the pressures generated by globalization. For many other regions, however, such as Latin America and Eastern Europe which had developed different welfare state models over many decades the picture does look grim - there are strong pressures pushing towards a more residualist model of social policy with so-called "targeting", "safety nets" and the like. But even here the picture is not homogeneous and there are noteable diversities even within these regional clusters.

Then the national state is not dead - it is more constrained, and especially when it comes to macroeconomic policies. But there are still policy choices to be made, and globalization should not be used as an excuse by governments for making choices that are unpopular - there is probably more room for policy maneuver than many claim. 
The fourth and final point that I wish to make is about the disappointing growth performance of the past two decades. In response to concerns that many organizations and individuals have been raising about structural adjustment policies and other neoliberal dictates over the years - for example concerns about rising levels of inequality, poverty and social exclusion - the routine response of those pushing for these policies has been that you should swallow the bitter "social costs" of economic liberalization because these policies will produce, and are producing, good rates of economic growth, which will eventually trickle down.

Well, it is increasingly clear that this is an empty promise which is not materializing in many regions. Not only have neoliberal policies failed miserably from a social point of view; it is also important to underline that for a great many developing countries these policies have also failed to produce decent rates of economic growth! The comparison of regional growth rates for the period 1960-1980 when developing countries were pursuing the much-criticised development policies associated with import-substitution-industrialization, with those for the 1980-2000 period, when they finally succumbed to the pressures from the IMF and the World Bank and "opened up" to world markets, leaves a big hole in the neo-liberal case for further liberalization. I will not repeat the figures because they are in the paper - but growth rates for much of Latin America and sub-Saharan Africa have considerably slowed down, and if you exclude China, the picture does not look very promising in Asia either.

Why is this so? Again, I will not go into the arguments as you are quite familiar with them. The two main causes of sluggish growth seem to be: first, the deflationary bias in neoliberal macroeconomic policies. The neoliberal macroeconomic agenda has been premised on increasing capital mobility, maintaining low inflation and reducing public debt (the golden rules that are not to be broken at any cost and under any circumstances) - and well, these policies have produced precisely what they were supposed to produce: mass 
incomes have been deflated and global capital is mobile as never before and is making very good returns thanks to low rates of inflation and high real interest rates.

And the second cause of low growth over the past two decades, many believe, has been the much higher frequency of financial crises in response to the much greater cross-border flows of capital (or financial liberalization). Many observers believe that this has imposed a high cost on the real economies of many countries, especially the so-called "emerging markets" that have suffered the worst strains from these financial crises.

Now I do not think that economic growth is the ultimate goal. Far from it. But I do think that it would be foolish to deny the difficulties of reducing poverty and enhancing human well-being when growth rates are sluggish. We all know, of course, the great success stories of the 20th century: Kerala, Cuba, Vietnam and other countries that managed to enhance human well-being despite very low rates of growth and low GNP. However, these are exceptional cases. Especially as the current policy climate condemns genuinely redistributive strategies as "no-go" areas, it is even more difficult to replicate such successes. So in a sense I agree with the argument made by Mark Weisbrot and others that "growth may be good for the poor", but World Bank and IMF policies have not been good for growth.

\section{PART TWO}

This takes me to the second part of my argument which is really the heart of the paper, and which essentially consists of three interrelated points.

First, I question the perception that certain policy-makers and some sections of the public in the North have that processes of trade liber alization over the past two decades have contributed to a significant shift in the structure of global manufacturing production, from the 
North to the South, which has brought about substantial employment gains in the South, while it has given rise to high rates of unemploy ment and low wages among unskilled workers in the North. What the paper argues, based on a number of recent studies by UNCT AD and a substantial report prepared for the South Centre by Ajit Singh and Ann Zammit, is that while the public concern about the deterioration in wages and employment in the North are all wellfounded, it is very difficult to attribute these changes to the rather marginal increase in trade with the South - in any case the North continues to hold a surplus in manufacturing trade with the South. Moreover even if there is a tendency for North-South trade to be detrimental to unskilled workers, this tendency can be overwhelmed by the "lift all boats" effect of faster economic growth. Which takes us back to the problems of deflationary macroeconomic policies that have paralysed Northern policy-makers in tackling employment problems.

Second, and more importantly, this paper questions whether NorthSouth trade and trade liberalization in manufactured products has in fact led to significant employment expansion in the South, as is often claimed. Two points are worth emphasizing.

(1) Much of the change in trade relations between the North and the South actually reflects shifts in the position of a small number of countries - the so-called Group of 13 (as the ILO labour economist Ajit Ghose refers to them). So here again the impact is geographically concentrated, even though this group includes countries like China and India, that are clearly very significant as far as the population of the developing world is concerned. The other developing countries have, by and large, failed to shift their export base from primary commodities to manufactured goods.

(2) Within this small group of developing countries the extent to which shifts in North-South trade have led to employment expansion seems to be rather limited. As the Indian economist 
Jayati Ghosh shows, while it is true that some countries like Malaysia, China, Indonesia and Thailand show a very impressive employment expansion over this period, this increase in only four countries takes place at a time when some of the most dynamic exporters like South Korea only show low rates of employment growth while in several large semi-industrial countries, like Brazil, Argentina and South Africa industrial employment growth was in fact negative in the 1990s. The important points to note here is that we are talking about net employment expansion which means any expansion due to exports minus any job destruction due to competition from imports - the other side of the coin when we talk about trade liberalization, since as we know tariff and non-tariff barriers have been halved in Latin America and East Asia over this period, leading to increased competition from Northern imports. So, as Ghosh argues, it is net expansion that we should be concerned about.

Third, a number of further important points emerge when we specifically look at female employment. I will summarize some of the main points that come out of the literature.

I would first like to underline the earlier arguments made by feminist economists like Susan Joekes and others, who have convincingly shown that industrialization in the context of globalization has been as much female-led as it is export-led and this was in many ways an exciting development which understandably attracted attention. I think that by the early 1990s, if not before, a consensus had emerged on this idea which considered the growth in international trade to be, on the whole, favourable to women's participation in the paid labour force. While some important elements of this assessment still hold true, I would argue that a number of trends since then in the employment patterns of developing countries raise notable questions. So what are these important qualifications?

(1) First, I think with all the excitement about women emerging as the new industrial work force, we somewhat under-estimated 
(and under-researched) another development, namely the fact that the expansion of export-oriented production processes and employment in export industries is taking place simultaneously with the destruction of jobs in other parts of the manufacturing sector. Indeed cheap imports flooding into developing countries due to poli cies associated with trade liberalization (like reduction of tariffs) threaten certain sectors. This is an area that I think has remained under-researched and now, as the pace of trade liberalization accelerates, it is becoming all the more urgent to document what is happening more carefully. It is simply not good enough to say that industries that are being affected by trade liberalization are the ones that provide jobs for a "male labour aristocracy". In the paper I give two examples, one from China and the other from Bangladesh, and in both cases I think there is evidence of job destructions probably affecting large numbers of women. In the case of China the evidence is more straight-forward and we know that the destruction of jobs in state-owned enterprises has affected significant numbers of women and that the trends are likely to intensify in the near future as China further reforms its state-owned enterprises. In the case of Bangladesh the evidence is more indirect, but the job destructions in the informal sector industries that are located in both urban and rural areas are probably affecting many women too who are hidden under the category of unpaid family workers. This is one important reason for being somewhat cautious about trade liberalization.

(2) I have already mentioned the second reason for being cautious, but I think it also has a significant gender dimension to it, and this relates to the slowing down of employment expansion in many countries. Even for those countries that are successfully expanding their exports, like Malaysia, Indonesia and Chile, there have been worrying signs that they are facing what economists call "diminishing terms of trade". In simple language this means that there has been a relative decline in the prices of manufac tured exports from the South compared to manufactured imports 
into the South from the North, so that as a Southern country you have to push out more and more exports in order to buy the same bundle of imports from the North. This trend has been carefully documented by UNCTAD and by several independent Asian economists who argue that manufactured exports from the South (e.g. garments, shoes) are more and more like traditional agricultural commodities. According to UNCTAD one of the reasons for this trend has been the low technology and wage content of manufactured goods in which Southern countries specialize that has kept export prices low. Thus as Gita Sen argues, to the extent that gender inequalities and gender biases have allowed these countries to keep wages very low, these have reinforced structural inequalities between the South and the North.

(3) You probably already know the third reason for caution since it was discussed at some length in the 1999 UN Report, World Survey on the Role of Women in Development, and this is the defeminization of manufacturing employment in several East Asian countries. In other words, since the late 1980s in many middle-income countries the demand for women's labour in export-oriented manufacturing has been weakening, as export production became more skill- and capital-intensive. As examples of this trend, the UN report cites Singapore, Taiwan, South Korea and the maquiladoras in Mexico. In South Korea specifically, it notes that the composition of the workforce in the electronics industry has changed in favor of male workers, as production in this sector shifted to more sophisticated communication and computer products.

I will not go into the specifics, since this issue is detailed in my paper, but I will just note that while de-feminization is more or less obvious - since we know that it is going on in countries as diverse as South Korea, Taiwan, Singapore, Malaysia and Mexico - the mechanisms are far from clear. There are competing hypotheses as to why women may be losing their employment position vis-à-vis men, which I try to explain in the paper. They are not very con- 
vincing and this is another area that needs to be looked at much more carefully.

So for all these reasons I think we need to be far more cautious before we celebrate the employment gains from trade liberalization for the South and for Southern women in particular. Finally I want to talk about the connections between female employment and entitlements or social rights.

\section{PART THREE}

Many see social policy as a handmaiden to industrialization whereby the state in effect subsidizes wages by underwriting labour costs for employers, including exporters, through the provision of subsidized food, housing, and social services of various kinds (health, education, training, childcare and so on) and by cushioning the risks of unemployment, sickness, old age and so on through social insurance programs. There are good reasons to think that, with varying degrees of success, the developmental states in East Asia, South Asia and Latin America performed such functions in the post-independence phase.

Now, the feminist critique of this historical record (not only in the South but also for some of the pioneer welfare states in Europe), to put it crudely, is that women were not granted social citizenship in the emerging welfare states - that they were treated as dependents of male breadwinners. The formal sector workers with social rights were predominantly men, while women only had indirect rights as their dependent wives or daughters. In sectors where women dominated as workers such rights were far less developed - think for example of the famous dormitories for women workers in export industries in some parts of East Asia - and their contracts were often casual.

So the important question today is how these limited, inequitable and gender biased models of social policy have been reformed and 
restructured since the early 1980 s when the old model was declared bankrupt and elitist. Is there a move towards a more gender-egalitarian and citizenship-based model of social policy? What kinds of social policies are replacing the old fiscally unsustainable and flawed models? I think some of the trends that we see - in pension and healthcare reform, which I say a little bit about in the paper - are far from encouraging. With the processes of privatization and commodification of social policy that are under way, the old male breadwinner model of social policy is being pushed aside in some places - men's employment is becoming more "flexible" as many have argued. But, as Diane Elson and Nilufer Cagatay have argued, the old male breadwinner model is not being replaced by a genderegalitarian reform of state-based entitlements that gives equal rights and entitlements to men and women for their different kinds of contributions to society. Instead in a significant number of countries state-based entitlements are drastically cut and replaced by a market-based individualized system of social services for the few (men and women) who can afford them, and elusive "safety nets" for the great many who cannot.

\section{Reference}

Razavi, S. (2001) Globalization, Employment and Women's Empowerment, Background paper prepared for the Division for the Advancement of Women (DAW), Expert Group Meeting, 26-29 November 2001, New Delhi, India. $<$ www.un.org/womenwatch/daw>. 


\title{
WOMEN'S AGENCY FOR GENDER JUSTiCE: EXPERIENCES OF AFRICAN WOMEN ${ }^{1}$
}

\author{
Bene E. Madunagu ${ }^{2}$
}

\section{PROTOCOL}

I feel greatly honoured to be invited to this very important event to share my experiences from the point of view of poor African women currently smarting under the pangs of globalization and its associated programmes. My perspective on this issue derives from an ongoing research conducted by Development Alternatives with Women for a New Era (DAWN) on the political economy of globalization.

\section{UNDERSTANDING GLOBALIZATION}

First I would like to describe my experience as the falicitator of a workshop on "Gender and Globalization" in Calabar, Nigeria, early

1 Excerpts of this presentation have been translated into French and published in $\mathrm{Ch}$. Verschuur (dir.) with F. Reysoo, Genre, mondialisation et pauvreté, Cahiers Genre et Développement, nº 3, Genève: iuéd-efi; Paris: L’Harmattan, 2002, 255 p., pp. 167-174.

2 Anglophone Regional Coordinator of Development Alternatives with Women for A New Era (DAWN), African Region. 
in 2001. When participants were asked what usually came to their minds when the term globalization was used the responses I got included: "worldwide"; "universal"; "technological advancement"; "part of the whole"; "explosion of ideas and information"; "everything about humanity"; "the way in which the world is becoming interdependent"; "global village", etc. All responses convey a feeling of irresistibility, something ordained and invincible. They also convey the notion that globalization is inevitable and unstoppable.

They also refer to the impression that globalization is, after all, not totally new or strange, since it appears to have common features with our extended family systems. Thus many ordinary people assume that globalization refers to the age-long communal life of traditional African families. That is what they understand by the global village. Renato Ruggerio, ex-director of the World Trade Organisation (WTO) once said, "we are creating a single global econ $o m y$ ". The images that this type of conceptualization of globalization convey substantiate the belief in the "gains of globalization" and its inevitability.

Following the responses by the workshop participants, questions were raised for the participants to illustrate their assertions with the realities of human existence and reproduction in the various communities they came from. At the end of the debate, the participants went into small groups to discuss in detail the politics that sustain globalization: privatization, deregulation and removal of subsidies from social services, etc. The outcome was a turnaround. Some of the outputs from the participants were as follows:

- "Globalization makes us aliens in our own country; globalization is causing greater economic margilization of the Third World countries like Nigeria".

- "It causes inflation and deepening poverty; it deepens gender inequality; it kills small scale industries; it provides cheap labour to foreign companies; it brings about affluence for a few, mostly 
men; it erodes empowerment of women; it brings about exploitation of the poor; it blocks local initiatives and excellence; it increases dependency and new forms of colonisation; it encourages the importation of foreign culture; it causes environmental destruction".

Eventually the participants unanimously reached a new understanding of the concept of globalization based on the realities of their lives as opposed to the slogans with which globalization is advertised and promoted. You can see that globalization creates intellectual poverty that deadens consciousness and so people gabble slogans without reflecting on the realities of their lives.

Globalization is indeed an "unequal movement and imposition of goods, ideas, information, services, cultural and economic activities in terms of production, distribution and consumption as well as unequal trade and investments across the political boundaries of nation states. It implies a growing openness of national economies to economic activity by companies and business institutions (private and public) from other political entities. It involves greater unequal interdependence between different national economies. It includes integration of local economy into global economy through forced harmonization of what is produced, exported and imported within a nation in accordance with the demands of international economy and following the dictates of the World Trade Organisation (WTO) the appointed 'referee' for the 'game' of globaliza tion. Most importantly, the focus is the promise of higher profits in response to uneven competition in the global market. This means that decisions taken by our governments in Africa, companies and even trade unions are influenced by WTO demands'3. Globalization goes beyond economic, social, political and environmental spheres as it impacts on mental and intellectual regimes as an opium, deadening consciousness so that the majority accept what is said uncritically. They do not see that the resources (human and material), the wealth and

3 Bene E. Madunagu: “Women's Alternatives in the New Era” (2001), Politica Internazionale. Bi monthly journal of Ipalm 1/2 January/April 2001; pages 63-69. 
the assets of the nations in the South are increasingly being concentrated in the hands of a few people - foreign and local - while the vast majority of the people including women and children are increasingly being dispossessed and driven deeper into poverty.

\section{The Challenges of Globalization}

Many African states have passed through different phases of economic restructuring programmes. From the 1970s to the mid-1980s, many African states adopted import-substitution and export-oriented production programmes. From the late 1980s, many of these countries opened their doors to the machination of the International Monetary Fund (IMF) and therefore started the implementation of structural adjustment programmes (SAPs). From the early 1990s they started endorsing trade liberation that led to the breakdown of trade barriers, turning these countries into dumping grounds for all sorts of foreign goods. As local industries could no longer compete with the "globalized" multinational companies, most of them entered great financial difficulties and eventually downsized; victims include millions of workers - the first to be affected are women.

With the withdrawal of government subsidies from social services, and the adoption of privatization in the face of inflation, mass economic hardship deepened while there was a sustained increase in the cost of all goods and services including food, health care, education, transportation, etc. This situation can hardly promote sustainable livelihood for African communities which members are mostly women. On January 1, 2002, in the name of deregulation - an ingredient of globalization - Nigerian Government increased the prices of all petroleum products. Labour leaders were clamped down by the police and prosecuted.

A number of recent events have shown an upsurge of civil society activism in some countries of the South in response to the challenges of globalization. For instance, in May 2001, a large number 
of Civil Society Organisations (CSOs) from Africa - East, West, South and North as well as the Middle East - met in Accra, Ghana, to discuss the challenges facing the peoples of Africa and of other developing countries as a result of globalization. The forum also provided the opportunity to develop framework for intervention by CSOs for effective confrontations with these challenges. Of major concern were issues surrounding WTO, the Cotonou Agreement and the US-Africa Growth and Opportunity Act (AGOA), paying particular attention to the dangers these issues create for the democratic rights and development of African economies and equitable needs of the people. An extract from the declaration issued in that meeting reads:

"The World Trade Organisation Agreements processes and the institu tions of the WTO are imbalanced against African and other developing countries. In essence, the agreements (in particular on agriculture, trade-related investments measures (TRIMS), trade-related intellectual property rights (TRIPS), services) serve principally to prise open markets for the benefits of trans-national corporations, at the expense of national economies, workers, farmers, women and other groups in the developing world, and the environment. The WTO system, rules and procedures are un-democratic, un-transparent and non-accountable and have operated to marginalise the majority of the people. Those governments that dominate the WTO systems have refused to recognise and address the problems. Instead, they have been pushing for further liberalisation through introduction of new issues for adoption in WTO".

Since Seattle civil society groups from Africa and all over the world have campaigned against the inequalities of the WTO system, which represents the globalization-global economic regulation. These campaigns focus on the revision of the existing agreements - which are grossly unequal - in order to protect the peoples' livelihoods and their right to development.

Governments in Africa and other developing countries have also mobilized to redress some of the imbalances and inequalities of 
globalization entailed by WTO agreements as the implementation of these agreements has damaged their economies and threatened the livelihoods of their people. This was clearly demonstrated at the Doha, Qatar, conference. There again, the major powers in the WTO showed their insensitivity by ignoring the protests of CSOs and the demands of the developing countries.

We must recall that in November 2000, the United States of America and the European Union colluded with the WTO Secretariat to use the Ministerial Workshop in Libreville, Gabon, to force African Ministers to support their plan for a new round of talks. This behaviour is unethical and arrogant and totally disregards the collective decision of the African team opposing the new round and even calling for a review of existing WTO agreements.

Different kinds of backdoor tactics have been adopted by the highly industrialized countries to introduce regional and bilateral agreements that have been difficult to push through WTO. Examples include the domestic law enacted by the US, the so-called African Growth and Opportunity Act (AGOA) and the Cotonou agreement. The AGOA is used to trap African governments forced to give up their legitimate rights under the WTO while securing opportunities for US businesses against the interest of Africa's domestic economic development. Through AGOA, the carrot of illusory benefits and profits is dangled before African countries in exchange for their adopting provisions relating to TRIPS, investment and financial liberalization.

Similarly, the Cotonou Agreement pertains to existing aid relationships between EU and African countries. The trade component of the agreement contains provision for African governments to comply with all kinds of dubious measures in WTO agreements. It further pressurises African countries to fully comply with the TRIPS agreements of WTO. African countries are required to negotiate for the adoption of provisions on consumption and investors protection which the EU sought for in the WTO but could not pass 
because of the opposition from African governments. They manipulate their information and communication technologies to extract agreements through backdoor tactics against people's interests.

In summary, globalization results in greater economic interdependence among countries through international trade, capital flows and international production, facilitated in its current form by new technologies of information and communication. Since discriminatory ideologies already exist and result in differential positions of women and men in productive and reproductive spheres and in terms of access, opportunities and control of resources as well as decision making/policy positions, globalization is bound to have serious repercussions on gender inequality.

\section{GLOBALIZATION AND GENDER: Women and Social Structures in Africa}

Since colonial times, African political and socio-economic structures have been built on the exclusion of women from the public sphere. The African family system provides the framework for inequality, male dominance and power and discriminatory gender roles between men and women with exploitation and subjugation of women at the core. Even the legal systems, while recognizing human rights, sanction male leadership.

Women in the traditional African context live and work at multiple levels of unpaid domestic work as daughters, sisters, nieces, wives and mothers. Girls and women care for male family members, young and old. These domestic engagements completely tie down the woman and leave her with no room for recreation or vacation, with serious implications on the health and status of girls and women. As healthcare services are declining and getting more expensive - thanks to privatization - women face additional difficulties in taking care of their health problems. Little wonder that 
as globalization digs deeper into the system, mortality rates of mothers and their infants increase.

Free-market global capitalism along with the policies of privatization, deregulation, trade and financial liberation that foster globalization have led to massive retrenchments. These retrenched workers have fallen back on families for social protection. Women and girls largely bear the burden of sustaining such families. This also means that women come under greater family and community control resulting from greater globalization. We know that with increased control comes greater gender-based violence.

Privatization has brought about all sorts of unholy alliances between the state and religious institutions. When the state abandons its functions of social services provision, religious and quasi-religious institutions step in, pretending to provide such services. These trade-offs between the state and religion place women under greater control and constitute a sell-out of women's health and rights. In certain situations, the ascendancy of religion has been seen to have serious adverse effects. It is alleged that in some African communities, where the HIV/AIDS pandemic has the highest toll on women, religious organizations go into shops to buy off condoms and burn them.

Advocates of globalization argue that it brings about economic growth, contributes to job creation and to poverty reduction. They pay little attention to the differential impact on women and men, perhaps forgetting or ignoring the fact that pre-existing structural gender inequalities in access to resources, power and decision making, already place women at a disadvantage. Williams ${ }^{4}$ puts it as follows:

"Gender inequality implications arise because trade liberalisation, per se, does not eliminate existing gender inequality in access to

4 Williams, Mariama: Gender, Trade Policy and the WTO. See web page: <http://www. modelwto.org/create/meetings/referate/woman.shtml>. 
resources, power and decision making. Rather, trade liberation may build on or exacerbate the negative conditions already affecting women's lives".

\section{Gender, Globalization, HIV /AIDS in Africa}

In many African communities, the socialization process makes young people believe that sexual intercourse is an appropriate return for gifts from male partners and puts people, particularly girls and women, at risk of sexually transmitted infections including HIV/AIDS.

As poverty deepens the phenomenon of female sexual exploitation for material and financial returns also progresses. Furthermore, increasing unemployment and underemployment occasioned by globalization has led to movements of cheap labour across borders, and then to increasing sex trade and hence increasing risks of HIV /AIDS infection.

Free trade, a strong conditionality of globalization has caused the dumping of all kinds of weapons and ammunitions in Africa and has provided the tools that are used to settle communal and ethnic conflicts by going to war. The displaced people and refugees resulting from such conflict situations are mostly women and children. This is another reason for the increased spread of HIV/AIDS in Africa, as girls and women get raped by both the warriors and the peace keeping forces.

These health problems are worsening as most African governments are unable to provide healthcare, a condition created by agreements in the implementation of globalization. 


\section{Gender, Globalization and Women Employment}

The notion internalized in most African communities is that the primary functions of African women is human reproduction and domestic responsibilities, while men are the "breadwinners" or "income earners", even where the relative contribution of women to the labour force and hence to the family income has increased remarkably.

Indeed, advocates of globalization have argued that it has encouraged women's participation in the market economy by creating new job opportunities. There are several dimensions to this issue. In poor rural communities in Africa structural barriers to women's access to education are such that women lack the training and skills for any employment that could raise their status. They become easily available for recruitment as cheap labour - to increase investors' profits.

In addition, women lack access to land and other productive resources. So they remain largely peasant farmers on a land they do not own, and then whatever they are able to produce is for household use as they work on small portions planting food crops. They have no access to fertilizer as the distribution is affected by macro economic policies designed and stipulated in WTO agreements on agriculture. Globalization deprives women of an access to modern techniques in agriculture and continues to confine them in subsistence farming to produce food for the family, while men have access to fertilizer and can produce cash crops for export. Thus agriculture, a sector where most African women are, is heavily gendered at their detriment - thanks to globalization.

More and more women are leaving the overworked lands to go into other communities to buy harvested food crops to sell. This process releases many women from the household that "tradition" regards as women's "sector". These women earn an income and are more directly responsible for part of household food provision and in 
many cases where the male is unemployed, these women become the major income-earner among poorer households.

Up to $80 \%$ of women, particularly in West Africa, combine paid employment with trading and are competing with men in the informal sector of petty-trading. Here again women have been the agents of change in their household and community sustenance. Women, whether in the strictly agricultural sector or in formal employment, skilled or not, are more and more involved in many forms of income-earning activities and becoming less and less dependent on male partners. They even earn more.

The response of the World Bank to poverty in Africa, has been to provide "micro credits" to women as an input in the various "Poverty Alleviation" programmes mounted by African governments. This is another dimension of gender discrimination. For why should women be pushed into micro credits? Why this marginalization of women? If society is now convinced about the inherent ability of women to be good managers, and therefore willing to trust them with loans, why should they be limited to "micro credits"? Who then controls the macro credits? At what cost to their lives do they have to struggle to repay these loans when the output go into family sustenance?

\section{“The Gains of Globalization”}

Women and the poor are generally the last to benefit from governemental measures in all spheres - economic, social or political. Government policies persistently lack of gender analysis and fail to analyse the likely impacts of implementation of such policies and impacts on women of changes in public expenditure schemes. Prior to the introduction of Structural Adjustment Policies (SAPs), most African countries health services for school children, maternity health services and family planning services were free for women and low-income groups. With the removal of subsidies from social 
services, a SAP conditionality, free social benefits were suppressed, and the conditions supporting women in meeting their physical and mental health needs disappeared.

The advent of the new forms of globalization further compounded the situation with the introduction of privatization. This is the background for women's lives in the context of globalization. Hence, even where more women have entered the labour market, which is considered as one of the "gains of globalization", two issues can be raised. First, would more women be in the labour market with or without globalization, given the increasing educational advancement of women resulting from social development? Secondly, what kinds of jobs are available in the labour market for women? How much have the gender stereotypic jobs improved the economic status of women given the expenditures occasioned by inflation, currency devaluation and privatization? So how gainful are these gains?

The opportunities that women and girls have to travel beyond local, regional and international boundaries are considered as other gains of globalization. Could some of these travels be violations of the rights of these girls and women through trafficking? Indeed, some of these girls and women may in fact consent to be transported to other places for greener pastures but they certainly do not necessarily consent to forced prostitution or slave-like labour which many of these victims face. Many of these travellers are poor, they have little or no education and also lack legal literacy and so have no chance in the formal labour sector. Consequently, they become vulnerable for cheap labour in the globalized world. It is therefore a lucrative venture to transport poor and ignorant girls and women from Africa and other developing countries to factories and industries of the industrialised countries for cheap labour to increase profit.

How can the migration of unskilled persons be a gain when they are exploited and their bodies even violated ? Yes, there are gains but we also need the gender lens to examine them closely. 


\section{CONCLUSION}

Women in Southern communities through their lives and through their strivings to sustain and reproduce lives in their families and communities, have shown that there are alternative paradigms of development - paradigms that address social development as human development and well-being. With "micro credits" and meagre gender discriminatory wages, they have made a difference in the lives of their communities. This then is about women's agency, their ability to perform different structural roles, to make a difference in sustaining lives at all levels and in all sectors. What needs to be done is learning and analysing and using this undervalued, unseen human agency - as demonstrated by the realities of women's lives - to create alternative frameworks for development and for sustainable livelihood. These poor women have demonstrated that there must be alternatives to these new designs of imperialism these new forms of globalization.

\section{References}

Antrobus, Peggy: Women's Perspective, DAWN (Development Alternatives with Women for a New Era), <www.twnside.org.sg/title/era-cn.html>.

Population Reference Bureau (PRB) "Conveying Concerns: Media Coverage of Women and HIV /AIDS". 


\title{
WOMEN, REPRODUCTION AND GLOBALIZATION
}

\author{
Silvia Federici ${ }^{1}$
}

\section{INTRODUCTION}

This essay continues a research that I started in the 1980s on the impact of globalization on women and the international feminist struggle. The framework for it came from the lesson I learnt from the wages for housework movement of the 1970s which stressed that the unpaid work by which labor is reproduced is the root of the exploitation of women in the capitalist society; for this labor is the main social function expected from us, and the pillar upon which every other form of work and the accumulation of wealth depend.

This framework - which has shaped my view of globalization has led me to formulate a number of theses that I first developed in Reproduction and Feminist Struggle in the New International Division of Labor (Federici 1995; 1999) ${ }^{2}$. These are as follows:

Hofstra University, Hempstead, New York.

2 A French version of this article has been published in Christine Verschuur (dir.) with Fenneke Reysoo, Genre, mondialisation et pauvreté, Cahiers Genre et Développement, n 3, Genève: iuéd-efi; Paris: L’Harmattan, 2002, 255 p., pp. 45-69. 
(a) We cannot understand the consequences of globalization on women and gender relations as long as we look at globalization only from the global restructuring of commodity production perspective and ignore, instead, the global restructuring of work that occurred in the 1980s and 1990s and by which human beings and labor-force are reproduced.

(b) The most significant developments in this context have been the crisis of the reproductive systems of the Third World, and the emergence of a New International Division of Labor (NIDL) whereby migrant women now do most of the work needed for the reproduction of the work-force in industrialized countries, especially in Europe and the U.S.

(c) Both developments have opened a crisis for the international feminist movement, as they are the manifestation of a deep deterioration in the social and economic status of women and of the determination of new power relations between first and third world women, replicating, in many ways, the power relations between women and men.

Reproduction and Feminist Struggle was written on the eve of the Beijing Conference of 1995. Seven years later, the conclusions which I presented there are well confirmed. In particular, it has become clear that the impoverishment that women have experienced in Africa, Asia, Latin America, the Pacific, and the former socialist countries is not a transitory phenomenon, nor a consequence of poorly implemented policy recommendations, as is often claimed by the World Bank, but a direct consequence of these regions' further "integration" into the global economy.

It is also confirmed that the initiatives undertaken by the United Nations to promote women's rights have been ineffectual; for despite four global conferences on women and a decade devoted to the promotion of women's rights, women's social and economic condition continues to deteriorate. Moreover, except for the cre- 
ation of a number of "Bureaus for Women's Affairs" (WEDO 1998) and a growing governmental concern with violence against women, the recommendations of the Platform for Action adopted at Beijing have not been followed in most countries ${ }^{3}$. Maybe it cannot be otherwise, since these recommendations are in conflict with the programs imposed on most Third World countries by the World Bank and the International Monetary Fund (IMF) - the main agencies driving the present phase of globalization ${ }^{4}$. In what follows, I substantiate these claims by examining the effects on women of the New International Division of Labor that has developed in the 1980s and 1990s, and by describing what some have called the "globalization of care". First however, I briefly discuss what I mean by "globalization."

\section{GLOBALIZATION AS GLOBAL PROLETARIANIZATION AND DISINVESTMENT IN THE REPRODUCTION OF THE INTERNATIONAL WORK FORCE}

"Globalization" has been described in different ways. In the literature emanating from the international financial institutions, it is portrayed as a more effective system of economic management, ensuring the free circulation of goods and enhancing the "comparative advantage" of different countries, each presumably utilizing its resources to the best effect for both local populations and world

3 The UN Development Fund for Women (UNIFEM) reported five years after the Beijing conference that only eight out of the UN's 188 members states have met the minimal indicators - greater gender equality in paid employment and education and women holding at least $30 \%$ of parliament seats. Indeed, there were some areas of the world like Eastern Europe that suffered a dramatic "gender equity" setback in the 1990s. For an analysis of the aftermath of the Beijing conference see also the series of reports published by African Agenda (Ocran 1999: 18-27 and Ocran 2000 : 33-35).

4 I write "the present phase" to remind the reader that capitalism was born as a world economy, and that 19th and 20th century colonialism were steps in a process of economic globalization. (Wallerstein 1974; Mies 1986; Potts 1990; Midnight Notes 1992). 
development. Policy-analysts thus stress the globalization of financial markets, capital investments, new technologies which, we are told, will lead in the foreseeable future to increased prosperity also in the "developing" countries.

Others, with an eye to the expectations generated in an earlier phase of this process, identify globalization with the migration of laborintensive industries to the Third World, once hailed as a factor of emancipation for women who represent the bulk of the work-force in the new industrial outfits.

My own perspective is that "globalization" is a strategy seeking to determine a process of global proletarianization and the formation of a global labor market as means to cheapen the cost of labor, reduce workers' entitlements, and intensify exploitation. These, in fact, are the most unmistakable effects of the policies by which globalization is driven.

But however defined, the social and economic consequences of globalization cannot be denied. After two decades of globalizing interventions in the world economy (creation of the World Trade organization (WTO), structural adjustment, TRIPS, etc.) one billion people live in conditions of "absolute poverty" (UN Population Fund 2001) $)^{5}$. Meanwhile, the Third World debt has increased from $\$ 800$ billion in 1980 to a staggering \$2,900 billion in 1999 (World Bank 2000), precluding the possibility of repayment, while the predicted industrialization of the Third World has not materialized

\footnotetext{
"Based upon an international poverty line of \$1 per day per capita, at 1993 prices, in 1998 there were 800 million people living in this condition just in Asia and the Pacific, amounting to $67 \%$ of the world's poor" (UNESCAP 2001). Asia and the Pacific also have the largest number of undernourished people, which has continued to grow, however, in three out of the five continents, especially between 1990-1992 and 1994-1996. <www.fao.org/NEWS/FACT FILE/FF9602-E.HTM>.

Symptomatic of the collapse of the reproductive systems in the Third World is the increase in the number of suicides among older women even in a country like in Argentina, where sociologists would have least expected it. ("The Days Dwindle Down to Poverty and Suicide." New York Times, 11/17 /92).
} 
despite the proliferation of Free Processing Zones (FPZs). In fact, industry-wise, much of the Third World has been further underdeveloped, due to the closures of state-subsidized industries and to import liberalization that has flooded domestic markets with cheap goods. How illusory the industrialization of the "South" has turned out to be is illustrated by the shrinking of industrial production in the aftermath of the Asian crisis of 1997-1999, in the very countries driving industrial expansion, including the four "Asian tigers" once upheld as a model for the rest of the Third World.

Most important, mechanisms are now in place - debt servicing, structural adjustment, import liberalization and, crucial to all, generalized warfare ${ }^{6}$ - that systematically lead millions of people away from their means of subsistence, uprooting them from their lands, their jobs, their countries, in what appears as the largest proletarianization and migration process since the turn of the 20th century (Federici $1992 ; 1999)$.

These, as I have already argued, are not unintended results. Rather, they are the consequences of a strategy that seeks not only to underdevelop the reproductive systems of the Third World, and thereby create a population of immigrant/refugee workers forced to accept work at any conditions, but also to undermine workers' entitlements in every country. Witness the fact that, at the dawn of the

6 As I have shown in War, Globalization, and Reproduction there is a close connection between the sudden proliferation of "ethnic" and "religious" wars over the last two decades and their expansion into global conflicts and economic and social globalization. Structural adjustment in itself is a form of warfare as it strips millions from their means of livelihood, and further instigates warfare as it blocks the traditional avenues to income and wealth, thus incentivizing plunder as means of accumulation. By causing mass unemployment and the disintegration of families and communities structural adjustment also makes young people and children available for recruitment into local armies (Federici 2000, 2001). Add Anthony H. Richmond's argument that "The transnational corporations that make up the global economic system... are united in their dependence on energy... and will stop at nothing to ensure a continued supply of cheap oil and cheap labor. [Thus] [t]he result of internal conflicts and external wars will be a mas sive increase in the number of refugees seeking asylum. [For] Social conflict has been global ized..." (Richmond 1994: 205). 
third millenium, coercion and slave-like forms of labor have reappeared also in the citadels of industrialization (Bales 1999), and the fact that, here too, once sacred, hard-won workers' rights (pensions, healthcare, job security) are questioned. Witness, above all, the insistence with which the World Bank and the IMF have continued, year after year, to impose their "structural adjustments programs" and neo-liberal agendas as the only possible alternative, despite the devastating effects they have had for the populations subjected to them, who literally look at them as a death sentence.

\section{WOMEN, REPRODUCTION, AND THE NEW INTERNATIONAL DiVISION OF LABOUR}

What precedes is my perspective on the impact of globalization on women. The first thing to be noted here is that we can no longer assume, as feminist economists once did, that globalization can "empower" women, through increased industrial employment providing them with a ticket to "modernization" and economic independence. Not only has mounting evidence documenting the coercive nature of work in the maquilas and the low wages attached to it dissipated much of the original optimism (NLC 1998; Madeley $1999)^{7}$. Such developments as the debt crisis, the policies of structural adjustment, and eventually the increase in female migration have been even more important than the advent of the "global assembly line", both statistically and socially.

The evidence for my claim is first of quantitative nature.

\footnotetext{
As Shahra Razavi, among others, has noted in her excellent presentation to this conference ("Globalisation, Employment and Women's Rights: a Southern Perspective"), women have not gained a more egalitarian relation with men from employment in the "global assembly line," as they have been excluded from all the social benefits to which workers were entitled in the past, in addition to very low wages. In other words, unlike what feminists economist anticipated women did not gain from the loss of male workers' power, nor were they able to get their autonomy throuh employment and earnings.
} 
After an apparent boom, in the early 1980s, female employment in Free Export Zones (FEZ) and other industrial outfits, as well as industrial activity as a whole, has been shrinking in the 1990s or stagnating in much of the Third World, even in the most promising cases, Asia and the Pacific (UNESCAP 2001) where, after the 1997-1999 crisis, industrial unemployment has risen, leading to the deportation of many workers, wages have fallen ${ }^{8}$, and the prospects for the future remain bleak in the face of a world commodity glut (UN 2001a) .

This assessment is confirmed by Shahra Razavi who points out that while trade liberalization has expanded employment in the export sector of a select number of Third World countries, it has also led to loss of jobs in their local industries, compounding the collapse of the public sector, (following the implementation of structural

8 According to the ILO Report, Towards Full Employment Prospects and Problems in Asia and the Pacific, by the end of 1998, unemployment in the region was $7 \%$ compared to $3 \%$ in 1997; in Thailand it was $5 \%$; in Indonesia 8 million jobs were lost. Real wages were also falling, by as much as 30\% in Indonesia; $8 \%$ in Thailand; and 5\% to $10 \%$ in South Korea. Quoted in Boonthan Sakanand, "Labouring Under the Crisis" InterPress Service (I/30/1999). Another consequence of the downturn following the Asian financial crisis was the deportation of many workers from other parts of Asia to which women were particularly vulnerable as they were concentrated in the most precarious forms of waged employment and thus most exposed to lay-offs and less easily reached by labor organizations (ILO 1998a).

However, as the case of Thailand suggests, female citizen-workers were also in trouble. The Labour and Social Welfare Ministry's record of job termination, which was collected from complaints lodged by workers and visits made to work-places from January 1 to November 30,1998, shows that 1,000 work-places, that covered 22 kinds of businesses, terminated employment of 47,634 workers from a total of 212,536 employed. Among the retrenched workers, $57.29 \%$ or 27,294 were women, from a total of 123,241 women employed (Prakankasemsuk 1999).

9 UN economists (UN 2001a: 97-107) reviewed the situation of the East Asian economies pessimistically. They write: "The slowdown in East Asia is expected to con tinue until the latter half of $2001 \ldots$ household income has been growing slowly, as the unemployment rate, though improved in many countries in 2000, has not returned to its pre-crisis level and the jobless rate rose again in early $2001 \ldots$ the manufacturing sector slowed sharply throughout the region in the fourth quarter of 2000, primarily in response to slowing exports." 
adjustment) where women are usually employed. In addition, manufacturing work is presently "de-feminizing", as men are taking over the jobs in the maquilas because of growing unemployment.

Noting that most international trade transactions still occur between countries of the OECD, Razavi concludes that the "global economy" is somewhat a myth, at least as far as women are concerned (Razavi 2002). But I would argue otherwise since the extent of globalization should not be measured on the basis of the global expansion of industrial investment, but rather on the capacity of policies such as SAP to determine a global pool of labor to be used in many different capacities and countries. In other words, what is crucial for globalization is the formation of a world proletariat (mostly women), increasingly formed of migrant/refugee labor to be employed in the industries of the North or, in the case of women, in the increasingly globalized reproductive sector.

We can see the significance of this aspect of globalization for women from the fact that whereas female industrial employment and wages have stagnated or fallen in the 1990s, the number of women migrating to other Third World regions or from the Third to the First World has continued to increase. (See Table 1 in the Appendix, showing that the number of women migrating from India, Thailand, and the Philippines is larger than the number of workers attracted to the domestic manufacturing sector in the postBeijing era).

According to the United Nations, between the mid-1970s and 1980s, in a migrant population of 118 millions, women represented 56 millions, that is $48 \%$. But by the mid 1980s, the figure had jumped to 77 millions (Stalker 1994 : 106). By the 1990s, women were migrating in higher number than men $^{10}$ and they were also beginning to migrate on their own, rather than as dependents of

10 In Asia, in the 1970s, only $15 \%$ of the migrant workers were women; by the 1990s, however, women were close to $50 \%$ of the migrants (Alyanak 1998). UNESCAP does 
male migrants. In the United States, where the predominance of female immigrants was first recorded in 1992 (US Department of Justice 1998 : 52), women now constitute a large percentage of the sans papiers, and in the case of settled undocumented Mexican immigrants, the largest (Chang $2000: 5$ ).

As for the countries of immigration, by 1990, 41\% of all migrants were in Europe and the U.S., where among the jobs migrant women could expect to perform, the most important one, numerically, was and is domestic labor, followed by entertainment, tourism, and health-care. Presumably, according to the ILO, as many as 350,000 undocumented female migrants work in the U.S. as domestics, but their numbers are undoubtedly higher, since domestics are statistically invisible whether they are documented or not (NCRW 1995).

Socially, this mass migration of women demonstrates the extent of the collapse of reproduction in the Third World and the former socialist countries, as well as the emergence of a new international division of labor (NIDL) whereby large parts of the work reproducing the work-force in industrialized countries is now performed by immigrant women. Then the people who clean people's homes and offices, take care of the children and the elderly, service the sexual needs of workers in Europe and North America are more and more often immigrant women, mostly coming from Asia, Latin America, Africa, the Caribbean islands, through a transfer of labor that some have labeled the "globalization of care."

I will return to this point later. What I want to stress here is that this phenomenon too cannot be seen as a consequence of a spontaneous evolution of economic dynamics. Different factors have cer-

not give a precise number concerning the percentage of women in the present migratory flow, but notices that, in 1997, it was approximately $78 \%$ for Indonesia and $16 \%$ for Thailand.

In 1990, 41\% of all migrants were in Europe and North America (UN1997). 
tainly contributed to it. Among them is the demographic decline in Western Europe, falling below replacement levels (Chell-Robinson 2000; United Nations 2000) ${ }^{11}$ in some countries (Italy, Spain, Switzerland, Sweden), but also the increase in extra-domestic female employment in industrialized countries, including the employment of mothers of young children ${ }^{12}$ that developed without any significant change in the distribution of domestic work within the family, or without any increase in public investment in child-care and other form of reproductive work. As for the reasons why Third World women seek domestic employment in Europe, the US, Japan, even when over-qualified, the "Declaration of Migrant Domestic Workers in Europe" (2001) states that some do it "because they can not make a living for themselves and their families in their home coun try;... some are fleeing conflict or war...; others need to pay for medi cine or education for their families..."

But as Cynthia Enloe (1990) and Grace Chang (2000) argued in their path-breaking works, the massive migration of women from the Third World, in the 1980s and 1990s should not be seen as an automatic result of push-pull factors. As Grace Chang writes in Disposable Domestics, what we have here is a carefully orchestrated strategy, pursued through the cooperation of international agencies, governments, and even religious institutions using the pauperization and social crisis opened by the politics of Structural Adjustment to force Third World women to migrate to Europe and North America, to take domestic jobs - the only ones available to them - so as to ensure that the reproduction of the work-force in

11 As Chell-Robinson wrote in 2000, "The Italian fertility rate is well below the 2.1 rate which assures [the] replacement of the population. Italy's 1.27 fertility rates is the lowest in Europe. The percentage of the population in the over-65 group in 1991 was 14.8 per cent and by 2001 will have reached 20.8 per cent." Italy is not a unique case. Declining population rates or Zero-population growth are recorded in other European countries such as Austria (-0.1), Greece (00), Germany (00), Spain (00), Sweden (-0.1), Switzerland (-0.1). (United Nations 2000).

1265 per cent of mothers of children aged six or under are now in the waged work-force in the US (p. 140). 
the metropolitan areas can occur at practically no cost for employers or at a cost no higher than that of unpaid domestic work (Chang $2000: 3-4 ; 13)$.

Chang examines, in this context, how the dismantling of welfare and the exclusion of immigrant women from any entitlements in the United States has contributed to this situation, preventing them from raising their children once arrived in the country, and thereby reducing the cost of their reproduction to a minimum (ibid.: 7-11). Thus, as she points out, migrant domestic workers pay the price of adjustment twice, first in their home countries and then in the countries of migration where their labor but not their reproduction is needed.

A similar point has been made by Cynthia Enloe in Bananas, Beaches and Bases, where she argues that the debt crisis and structural adjustment have allowed financial organizations like the IMF and the World Bank to respond to the crisis opened by the feminist movement of the 1970s on the family front and which expressed itself through a massive refusal of unpaid domestic labor through its redistribution on the shoulders of Third World women. Like Chang and others (e.g. Anderson 2000), Enloe also demonstrates the complicity of indebted Third World governments in this process, for whom the remittances sent by immigrant women often constitute one of the main sources of their foreign currency earnings (Enloe 1990 : 187-188). In Doing the Dirty Work (2000), Bridget Anderson adds an account of the involvement of religious organizations, like CARITAS who has become one of the channels through which migrant domestic workers become linked to their future employers (Anderson: 36, 52-53).

From a neo-liberal perspective, then, a perfect fit would seem to have been achieved between the needs of Third World and Eastern European women trying to feed their families and refusing total pauperization, the needs of women in industrialized countries increasingly employed out of their homes even when they have 
young children, the needs of financial organizations who see in the export of women a means for indebted countries to pay their external debts, and the needs of the governments which, in Europe and the US, through female migration, can cut the cost of labor, and in the Third World, can fill the state reserves with "hard currency" and free themselves from a potential source of unrest ${ }^{13}$.

But this situation actually demonstrates that women's "integration into the global economy" is in fact a further transfer of resources from the Third to the First World and a theft of women's labor, since employers in the countries of arrival benefit from the labor of workers whose social reproduction they never paid for.

Moreover the cost is high for by migrant women who often risk their lives just in the attempt to enter a country, and then must face years of loneliness and anxiety as they are separated from their families and must work in environments hostile to them. The families of the immigrant women pay a high cost as well, and above all their children $^{14}$, who are left in the care of paid nannies, who in turn leave their own children in the care of other women (Hochschild 2000, 136). We are reminded here of Arlie Russel Hochschild's argument that today's global economy does not only consist of transfers of money and capital but of global transfers of love also, which ultimate beneficiaries are multinational corporations in their efforts to portray themselves as a "one big family" to their employers (ibid.: 141).

13 Overseas workers are a major source of foreign currency earnings in many countries. In 1997, these remittances amounted to $\$ 10.33$ billion in India; $\$ 6.79$ billion in the Philippines; $\$ 1.74$ billion in Pakistan; $\$ 1.4$ billion in Thailand; and $\$ 1.52$ billion in Bangladesh. These figures do not include the remittances that are sent through informal channels which, in some cases, can be as high as those sent through the formal ones (UNESCAP 2001 : 140).

14 See on this topic Feizal Samath's description of the consequences of women's migration in Sri Lanka, where she shows that their leaving has spawned a host of social problems: alcoholism, extramarital affairs, incest, juvenile delinquency. 
As nowadays immigrant domestic workers are mostly hired by women who are themselves recipients of relatively low wages and vitally interested in keeping the wages of their "helpers" as low as they can; as housework is still not considered a "real work" and as, working apart from each other, domestic workers rarely manage to have their work contracts fully defined and respected; as they are not only required to perform physical labor but also "care" (Hochschild 2000; Anderson 2000 : 114-121) while at the same time, they must live with the threat of seeing the ties which they create with the people they assist broken from one moment to the next; obviously paid domestic work can easily turn into a new form of domestic slavery, the more so as immigration laws make domestics vulnerable to abuse. This not just a metaphor. Coercion, applied in many ways, is a widespread practice in every country, and is bound to grow as more restrictive immigration laws are passed, giving employers more power to blackmail those who work for them" ${ }^{15}$. Thus, as the "Declaration of the Migrant Domestic Workers in Europe" states on this subject:

"According to statistics from all over Europe the majority of us will suf fer psychological abuse in the work place; many will be locked into the house or made to sleep on the floor. Most of us will work very long hours for very little pay. Some of us will not be paid at all, and some of us will suffer from sexual and physical abuse". (Abramsky 2001 :215)

By stressing these facts I do not wish to picture migrant workers as passive victims of economic necessity, nor ignore the fact that migration is a form of struggle, the expression of a refusal of pauperization and/or patriarchal family relations. Nor do I suggest that domestic labor is less valuable or necessary than other forms of work. Yet, my point is that: (a) the decision to migrate is generally made under very adverse conditions and cannot be used to claim that globalization opens new "career opportunities" to women; (b) indispensable

15 Exemplary is the law passed in early March 2002 by the Italian government that makes residence for immigrants dependent on a work contract. 
as it may be for millions of families and individuals to employ a domestic worker, it cannot be considered as the solution to the problem of the daily production and reproduction of life and labor, and even less as a path to women's solidarity and liberation.

Mary Romero's work (1992) gives a crucial insight into the pitfalls of the "marketization of care". She argues that the growing employment of domestic workers in the U.S. has contributed to buttress the "traditional", patriarchal sexual division of labor within the family which the feminist movement had challenged, but spared women the task of convincing their male partners and children to share the housework (ibid.: 102) and blunted the struggle for the social recognition of reproductive labor as work. Romero's point is proven by statistics, showing that, despite the increase of extra-domestic employment, the performance of household chores still remains the responsibility of the woman who, in the absence of a maid, performs the bulk of domestic work. The same dynamic also prevails at the institutional level where, despite the lip-service paid to the social value of housework, even in "high income" countries of the "North" nothing has been done to break down the social and economic divide between the production of goods and the production of human beings. In fact, in a climate of rampant neo-liberalism, this divide and the higher estimate given to commodity production at the expense of the production of human beings are today stronger than ever. In the US, Aid to Dependent Children, which recognized the work of sole mothers has been gutted (Abramovitz 1996 : 349365) and so have other forms of public investment in reproduction. Then after two decades of feminist struggle, women still have to choose between family and "work," caring for their children or economic independence, social isolation or a "job like a man," that is a job leaving no time for family and communal relations ${ }^{16}$.

16 It is significant that even women who have a high degree of social power do not escape this dilemma. Thus as a recently released US General Accounting Office study of female and male managers' lives indicates about $60 \%$ of female managers do not have families, while $60 \%$ of male managers do (Goldstein 2002). 
Another aspect of the global restructuring of domestic labor demonstrates the high cost that all women are paying for it, and the ways in which globalization thwarts the possibility of women's liberation: the new and deeper power relation between the impoverished women in the Third World - a term that now can be extended also to the former socialist countries - and their domestic employers in the homes of the First world. Far from contributing to women's liberation, it is indeed something of a scandal that, in the very decades when international feminism has come of age, the relation through which First and Third World women have most commonly met, at a mass level, has been that of madams and maids.

Unfortunately, North American and European feminists have rarely raised this issue, to the detriment of their cause, I would argue, since ignorance on this subject can only sanction a colonial relation, undermining the bonds presumably fostered by international feminism. It is difficult, in fact, to imagine how an international feminist movement can be built at a mass level, if the power relations and divisions that globalization creates among women are not overcome. Meanwhile, those who are addressing this question are immigrant domestic workers, who, despite the difficult conditions to which their legal status and the lack of resources confine them have been in the forefront of the struggle against the conditions of domestic work as well as the struggle for the expansion of investment in reproduction.

\section{CONCLUSION}

The situation which I have described only touches upon a part of the reorganization of reproductive labor produced by the new global economy, and is just one window on the negative consequences of globalization for women. A full picture in fact would include (a) the development of an international baby-market which enables women in the First World to have the chidren they want, either through surrogacy or adoption, without sacrificing their 
health or their career; and (b) the globalization of the sex industry, which no less than many other forms of migrant work, in now in good part built on coerced labour, providing workers, at a time of falling wages and rising unemployment, a cheap safety valve for their frustrations.

What we find, in both cases, is that, with migrant domestic work, the underdevelopment of reproduction in the Third World serves to create a a situation of "debt bondage" whereby governments are ready to surrender their citizens in exchange for increased revenues (Chang, 2000), and women themselves are willing to take very high risks, including the risk of death and enslavement, not to be trapped in the type of misery the World Bank and IMF and their military backers have in store for them.

Thus, an international feminist agenda must first demand the termination of the neo-liberal policies which are now driving globalization. In particular, it must demand that the Third World debt be cancelled and the World Bank's adjustment programs be immediately phased out, for these are the main obstacles to women's access to basic resources such as land, employment, a sound environment, healthcare, and and not have to risk their lives or separate themselves from their children to make ends meet. On a broader level, what needs to be phased out is the global dictatorship of the companies and financial institutions which now shape world politics, with their political and military backups. Otherwise neither high sounding declarations nor the passing of laws banning gender-based discrimination and violence against women will do. For the violence that women confront is not domestic violence alone, but the institutional violence inscribed in economic programs that sustain globalization and the immigration laws that rule workers' mobility within the global economy, whose effect is to maximize the exploitation of immigrant labour.

Thus, a further priority for international feminism must be the campaign for immigrant rights - beginning with the right to enter 
a country - and the rights of refugees seeking asylum. At the same time, it is crucial that feminists re-launch a struggle over housework if this unpaid labor is not to continue to circulate in the social body, to be periodically shifted on the shoulders of other women. Housework is a necessary labor and should not be degraded, as it inevitably is when those performing it are not paid or are paid at the lowest level, in terms of the money received, the hours worked, and the social relations surrounding their work. It is time we realize in fact that once generalized, the strategy pursued by the individual "madam," trying to reduce the cost of "her" maid's work to a minimum, turns into a social disaster. It may save the family's budget, but it institutionalizes the degradation of social reproduction and as such it is cannot be sustained.

What is needed, then, is a social struggle to make housework compatible with the requirements of self-determination. This is where the struggle for immigrant women's rights meets the struggle for pensions, good housing, universal healthcare, access to land and, in the cities, access to urban gardens, now feeding a billion people across the planet but increasingly under attack. This struggle is especially timely as new trade negotiations, initiated in Doha (Qatar) are attempting to carry globalization to its logical conclusion and globalize all services, including reproductive ones, from cleaning companies to hospitals, old age centers and day-care centers, so that in completion of the neo-liberal dream, reproduction of all humanity should pass through the narrow gate of the market. 


\section{Appendix}

Migration versus manufacturing employment: 1995-1999 (in thousands)

\begin{tabular}{lcc}
\hline Country & $\begin{array}{c}\text { Average annual } \\
\text { migration }\end{array}$ & $\begin{array}{c}\text { Average annual increase } \\
\text { in manufacturing } \\
\text { employment }\end{array}$ \\
\hline India & 140 & 83 \\
Indonesia & 180 & 348 \\
Thailand & 40 & 5 \\
Philippines & 120 & 65 \\
\hline
\end{tabular}

Calculated from UNESCAP (2000) and UNESCAP (2001). 


\section{References}

ABRAMSKy, K. (ed.) 2001 Restructuring and Resistance. Diverse Voices of Struggle in Western Europe. London.

ALYANAK, L. 1998 “'Reverse' Migration in Asia." HURINET (8/28/98).

Anderson, B. 2000 Doing the Dirty Work? The Global Politics of Domestic Labour. London: Zed Books.

ANThiAs, F. and G. LAZARIDIS (eds.) 2000 Gender and Migration in Southern Europe. Women on the Move. New York: Berg.

BALEs, K. 1999 The Disposable People. New Slavery in the Global Economy. Berkeley: University of California Press.

Boyle, P. M. 1999 Class Formation and Civil Society: The Politics of Education in Africa. Brookfield (USA): Ashgate.

Caffentzis, G. 1999 "On the Notion of a Crisis of Social Reproduction." In, Dalla Costa, M. and G. F. Dalla Costa (eds) 1999 Women, Development and Labor of Reproduction. Struggles and Movements. Trenton (N.J.): Africa World Press

Carvajal, D. 1996 "For Immigrant Maids Not a Job but Servitude." New York Times. $(2 / 25 / 96)$.

Chang, G. 2000 Disposable Domestics. Immigrant Women Workers in the Global Economy. Boston: South End Press.

CHANG, G. 1992 “Disposable nannies: Women's Work and the Politics of Latina Immigration." Radical America. Vol.26, N.2. April-June (9-22).

Chell-Robinson, V. 2000. "Female Migrants in Italy: Coping in a Country of New Immigration." In Anthias, F. and G. Lazaridis (eds.) 2000 Gender and Migration in Southern Europe. Women on the Move. New York: Berge. 103-123.

Colatrella, S. 2001 Workers of the World. African and Asian Migrants in Italy in the 1990s. Trenton (N.J.) : Africa World Press

Dalla Costa M. and F. Dalla Costa (eds.) 1999 Women, Development and Labor of Reproduction. Struggles and Movements. Trenton (N.J.): Africa World Press.

“The Days Dwindle Down to Poverty and Suicide." New York Times, 11/17/92

Declaration of the Migrant Domestic Workers in Europe. In Abramsky, K. (ed.) 2001 Restructuring and Resistance. Diverse Voices of Struggle in Western Europe. London 2001. (214-217).

Ellwood, W. The No-nonsense Guide to Globalization. Oxford (UK): Verso. 
Enloe, C. 1990 Bananas, Beaches and Bases. Making Feminist Sense of International Politics. Berkeley: University of California Press.

FAO FACT FILE, (http:/www.fao.org/NEWS/FACTFILE/FF9602-E.HTM)

FEDERICI, S. 1992 "The Debt Crisis, Africa, and the New Enclosures." In Midnight Notes (ed.), Midnight Oil: Work, Energy, War.1973-1992. New York: Autonomedia. (303-316).

Federici, S. 1999 "Reproduction and Feminist Struggle in the New International Division of Labor." In Dalla Costa M. and F. Dalla Costa. (eds.) 1999 Women, Development and Labor of Reproduction. Struggles and Movement. Trenton (N.J.): Africa World Press. (47-82).

Federici, S., O. Alidou, G. CAFFentzis (eds.) 2000 A Thousand Flowers. Social Struggle Against Structural Adjustment in African Universities. Trenton (N.J.): Africa World Press.

FEDERICI, S. 2000 "War, Globalization, and Reproduction." In Peace and Change. A Journal of Peace Research. Oxford (UK): Basil Blackwell, Vol. 25, N.2, April 2000 (153-165). Reprinted in: Benhold-Thomsen V., Faraclas N., Von Werlohf C. (eds.) 2001 There is an Alternative. Subsistence and Worldwide Resistance to Globalization. London: Zed Books (133-145).

Goldstein, R. 2002 “Executive BitchSlapping.” In Village Voice, March 5, 2002, 47.

National Council for Research on Women (NCRW) 1995. "The Feminization of Immigration: Give us your tired, your hungry, your poor, no more." Issues Quarterly, Vol. 1, N.3, 12 B1.

Hochschild, A. R. 2000 "Global Care Chains and Emotional Surplus Value." In Hutton, W. and A. Giddens (eds.) 2000 Global Capitalism. New York: New Press. (130-147).

Hutton, W. and A. Giddens (eds.) 2000 Global Capitalism. New York: New Press.

ILO 1998 The Social Impact of the Asian Financial Crisis. Geneva

ILO 1998 Towards Full Employment. Prospects and Problems in Asia and the Pacific.

Matteucci, I. (ed.) 1991 In Casa D'Altri. Sedici immigrate filippine si raccontano. Roma: Datanews.

Madeley, J. 1999 Big Business Poor People. The Impact of Transnational Corporations on the World's Poor. London: Zed Books

Mies, M. 1986 Patriarchy and Accumulation on a World Scale London: Zed Books.

MorINI, C. 2001. La serva serve. Roma: DeriveApprodi. 
Meroli, E. and P. ARlacchi 1999 Schiave d'Occidente. Milano: Mursia

National Council For Research On Women 1995 "The feminization of Immigration: Give us your tired, your poor, your hungry, no more." Issues Quarterly. Vol.1, N.3. (12/31/1995).

National Labor Committee (NLC) 1998 The Peoplés Right to Know Campaign. New York: National Labor Committee.

OCrAN, S. 1999 “Long Way from Beijing Mandate” African Agenda, Vol 2, No. 1 , pp. 18-27,

Ocran, S. 2000. "Women 2000 Ends with Belated Agreement on Outcome Document." African Agenda, Vol. 3. No. 4, pp. 33-35.

Pотт, L. 1990 The World Labour Market. A History of Migration. London: Zed Books.

PraKANKASEMSUK, S. 1999 The Labour Situation in Thailand 1999 : Thai Workers in an IMF Era (CLSITO).

RAZAVI, S. 2002 Globalization, Employment and Women's Rights: A Southern Perspective. Paper presented at the "Economie mondialisée et identités de genre" Conference. Institut universitaire d'études du développement, in Geneva, January 25-26, 2002.

Richmond, A. H. 1994. Global Apartheid. Refugees, Racism, and the New World Order. Oxford: Oxford University Press.

SAKANAND, B. 1999. "Labouring Under the Crisis." InterPress Service. (I/30/1999).

SAMATH, F. 1999 "Gulf Dreams Spawn Social Problems." IPS, 1/4/99.

STALKER, P. Workers Without Frontiers

StALKER, P. 1994 The Work Of Strangers: A Survey of International Labour Migration. Geneva: International Labour Office.

United Nations (2001). The State of the World Population 2001. New York United Nations.

United Nations 2001 World Economic and Social Survey 2001 : Vulnerability in a Globalizing World. New York: United Nations.

UNESCAP 2001. Economic and Social Survey of Asia and the Pacific 2001. Bangkok: UNESCAP.

UNESCAP 2000 Statistical Yearbook for Asia and the Pacific. Bangkok: UNESCAP.

United Nations 2000 The World's Women 2000 : Trends in Statistics. New York: United Nations Statistics Division. 
United Nations Population Division 1997 International Migration and Development. The Concise Report. New York: The United Nations.

United States Department of JUstice 1999 Legal Immigration, 1998. Washington D.C.: US Department of Justice

WoMEN ENVIRONMENT AL AND DEVELOPMENT AL ORGANIZATION (WEDO) 1998 Mapping Progress: Assessing Implementation of the Beijing Platform. New York: WEDO.

World BANK, World Development Report 1999/00. Washington, D.C.: World Bank. 


\title{
Alternatives for Sustainable DeVelopment AND GENDER EQUALITY: A Case Study from Sierra LeOne
}

\author{
Fatmata Lovetta Sesay ${ }^{1}$
}

\section{INTRODUCTION}

It is generally accepted that women in developing countries live in a desperate economic situation. Yet there is little consensus as to what the problem is and therefore how it needs to be tackled.

In the light of the "booming industry" of development agencies, it is time to evaluate how efficient and effective their work has been especially with their gender policies, and above all to evaluate the sustainability of programmes when agencies "poll out".

Alternatives for Sierra Leone can be looked at from a perspective of increasing gender participation in the economic, political and decision making spheres.

This paper will however focus on women's roles within the framework of sustainable development in Sierra Leone, since women are

1 Phd student in München at the moment, focussing on the issue of globalisation and gender in Sierra Leone. 
the ones marginalized and thus those whose status needs to be improved to equate that of men. I will first address the key terms in the topic:

\section{GENDER}

People often use the word "gender" as a synonym for "sex." Sex, however, refers to biological characteristics that make someone female or male. Gender has also been misused as a synonym for "women" or "female." Development projects directed toward women's needs, for example, may mistakenly refer to gender needs. Instead, gender refers to the socio-cultural construction of roles and relationships between men and women. In describing socio-cultural construction, gender analysis considers other social structures such as race, ethnicity and class.

Gender roles and relationships are the assigned activities and relative positions of men and women in society. These help to determine access to opportunities and resources based on local cultural perceptions of masculinity and femininity. While gender roles and relationships impose expectations and certain limitations on both women and men, they can perpetuate forms of subordination.

More important about the term gender is describing it in a particular framework and hence the Sierra Leonean mentality. In Sierra Leone, gender is connotatively referred to as a set of educated women who are either by misfortune or otherwise not married and who will not want to be married simply because they do not want to be under the control of a man. The society looks at an ideal woman as one under the control of a man and as a devoted wife and mother, and deviants are referred to as gender activists who want others to be like them. 


\section{Sustainable DeVElopment}

Sustainable development is often defined as development that meets the needs of the present without compromising the ability of future generations to meet their own needs. Although easily said, bringing these concepts to life requires a delicate balance between the planet's social, economic, and ecological systems and a shared vision of the type of future we want for the world.

Sustainable development can come about only through sustained commitment and cooperation on the part of all the world's people, in both rich and poor countries.

\section{GENDER EQUALITY}

The status of women has improved considerably in Sierra Leone in the past two decades. Yet in no part of the country do women enjoy equal legal, social, and economic rights. Women have fewer resources than men, and more limited economic opportunities and political participation. Because gender gaps are often largest and most costly among the poor, gender equality is a core development issue. Gender inequalities persist because they are supported by social norms and legal institutions, by the choices and behaviors of households, and by regulations and incentives that affect the way economies function.

At this point I would like to ask a question reflecting the reasons for our being here today. Why is gender inequality of importance to development? We all clearly have the answer. The obvious answer is that gender inequalities hinder development. In short, women have a profound and pervasive effect on the well-being of their families, communities, and local ecosystems. Therefore, inequities that are detrimental to them - be it to their physical and mental health, income-earning ability, education and/or decision-making power, to name a few - are detrimental to society at large and to the environment and economy as well. 


\section{Gender Inequality and Sustainable Development}

Sustainable and equitable development gives overriding priority to meeting the basic needs of the world's poor; and it emphasizes social equality between all peoples now, as well as a responsibility to future generations. Sustainable and equitable development suggests that national governments must not only work to alleviate poverty but also to address the great disparities in wealth and quality of life between the "haves" and the "have-nots." And women are often among the most vulnerable "have-nots". In Sierra Leone, women do not have the same opportunities as men. While the situation of women has improved, marked disparities exist almost everywhere in the country.

From all evidence the alternative to sustainable development in Sierra Leone is to enhance gender equality in all spheres of life. This should start with a reformulation of laws, especially family law.

Arguing on gender equality and economic development always reminds me of the egg and chicken situation. The problem is always to determine which one comes first; the "egg or the chicken". Implicitly, it it assumed that gender equality will bring about economic development and economic development will bring about gender equality. I am a proponent of the first solution where gender equality leads to economic development as opposed to economic development leading to gender equality, because economic development is not the only factor affecting gender inequality. Norms, laws, attitudes, religion, practices, etc., all have their own share of the blame for gender inequality. Hence, it is unsafe to assume that economic development will lead to gender equality. But when all mentioned elements have been treated in order to allow gender equality, then economic development is ensured. 


\section{OVERVIEW ON THE STATUS OF WOMEN IN SIERRA LEONE}

There are many factors affecting a woman's status in Sierra Leone and what opportunities she has to control and influence her life-situation.

\section{GOVERNANCE}

The basic document of a country's legislation is its Constitution. The Constitution of Sierra Leone states that it is not allowed to discriminate against any citizen on the basis of sex and that all citizens of Sierra Leone have equal rights to vote.

The problem for Sierra Leonean women is not their legal rights. Women in Sierra Leone are protected by the laws, but the problem is that the laws are not followed in the society. Most women are not fully aware of their rights and opportunities and they are not encouraged to learn about their rights, hence the political awareness is often low. A woman's fulfillment and identity come from marriage and motherhood. These are also her roles in life. Women are discouraged to participate in decision-making. Their situation is even worse in rural areas where they have been relegated to the kitchen. Women do not even come close to constituting one fourth of the national legislature of Sierra Leone.

What is of importance for Sierra Leonean women in relation to the law is that investigations have revealed that large masses of women in Sierra Leone have remained unaffected by the rights guaranteed by the Constitution.

Women experience differences in everyday life, and local governance is very much engendered. Traditional gender roles corner women into juggling with multiple responsibilities at home, at the workplace and in the community. The demands on women leave them with less time than men for political involvement, and with 
no voice in the decision-making processes that impact on their lives and environment.

\section{EDUCATION}

Although the overall literacy level is progressing, there still persists a difference in literacy among women in rural and urban areas. Women make up nearly two-thirds of the over $80 \%$ of the total illiterate population. There are more boys than girls in schools at all levels. Dropping out from school occurs when the children (girls) have to stay at home to take care of younger siblings or engage in petty trading to help their parents with the income, or in case of teenage pregnancy in urban areas. Dropouts are mostly girls.

I see education as the key to sustainable development for women. Even with the greatest share of the billions of dollar micro-credit schemes, a lower education, especially on how to manage resources, will always be an obstacle to equality. The old saying "when you educate a man, you educate and individual and when you educate a woman you educate a family" is a justification for policies that enhance female education.

\section{UNEMPLOYMENT}

Many people who move to big cities come from rural areas and have been working in the agricultural sector. They often have to switch to another occupation, if they find work at all. Finding a job is difficult as many of them can hardly read and do not have any special skills. The Census reports show higher unemployment rates among women than among men. Women have less than one third of the jobs on the market and less than $10 \%$ of administrative and managerial positions in the country.

Women's work often do not appear in economic official reports as the work they perform at home or in the informal sector is not taken into account in the country's GNP. Most women in the infor- 
mal sector are still engaged in agricultural activities. The informal sector is predominantly composed of small scale businesses financed by small amounts of local capital, indigenous and often based on the family and kinship network. Technology is limited and the enterprise is likely to be labor-intensive. Earnings in this sector are on or below the minimum for subsistence and the majority of women engaged in this sector are marginalized.

In Sierra Leone a majority of the women who earn money are working in the informal sector and have not made any major gains in terms of employment. Statistics show a decrease in employment opportunities for women who used to work in the public sector as a result of privatization. This is one of the inevitable negative effects of globalization on women in developing countries. This increase in unemployment has not been accompanied by a parallel increase in employment opportunities in the private sector. The prices of food have gone up significantly while women's wages have declined in real terms.

\section{HEALTH}

The need for reproductive health services is particularly great among adolescents, who account for the majority of births and abortion each year.

Almost 60 percent of the people of Sierra Leone depend on unimproved water supplies to meet their daily needs. Urban populations are better served than rural populations, but even piped water from municipal supplies may be contaminated by disease-bearing organisms and pollutants. Women are the most affected by this problem of clean water as they do all the cooking, laundry, and cleaning. Thus in case of an outbreak of any waterborne disease, women are the first victims. 


\section{ENVIRONMENT}

Sustainable development depends on the environment providing a variety of goods and services - now and in the future. But the connections between environmental conditions and human welfare are complex. Environmental changes can worsen poverty by compromising health, livelihoods, and protection from natural disasters. And economic growth can create new stresses on the environment as the demand for environmental resources rises and the damaging by-products of economic activity accumulate. But environmental resources are needed to promote economic growth and reduce poverty, and growth itself creates the means and the demand for an improved environment. Though there are laws to preserve the environment in Sierra Leone, they are poorly enforced. Moreover there is limited or almost no monitoring system for conservation.

Most household energy in Sierra Leone is still generated by burning wood and other biomass, most of it gathered by women and children. Women use forest products to make household items such as bowls, mats, and baskets which may also be sold to generate income Women are disproportionately affected by these bad environmental conditions because they are the caretakers of families. They are particularly vulnerable to shocks from environmental change and natural catastrophes.

Women also bear the worst consequences of environmental policies that ignore the principles of sustainability such as overfishing and industrial logging, which has now become a great environmental factor in Sierra Leone. When large tracts of forests are destroyed, or when technology displaces workers, women have to cope with the increased difficulties of the day-to-day survival of their families. 


\section{LAND AND AgRiculture}

Access to farmland in Sierra Leone plays an important role in the economic well-being of the rural population. Land ownership in Sierra Leone can broadly be divided into three categories: customary ownership, state ownership and a partnership between the state and customary owners. The fundamental principle upon which ownership of land is based in Sierra Leonean communities is collective ownership by a community or group. Customary ownership occurs where the right to use or to dispose of use-rights over land rest on the fact that they are recognized as legitimate by the community. The rules governing the acquisition and transmission of these rights are usually explicitly and generally known, though not normally recorded in writing. Such ownership occurs mainly through discovery and long uninterrupted settlement or gift from another land-owning group or traditional overlord.

In Sierra Leone the land rights of women are insecure in rural areas. Women's access to agricultural land is only guaranteed through the husband or a male member of the family. This in itself is considered unfair. Women's contribution to agriculture is significant as farming in Sierra Leone is largely unmechanized.

Two very important aspects of gender equality in Sierra Leone are worth mentioning when we talk about women and economic development: the Gender-Related Development Index and the Gender Empowerment Measure.

\section{Gender-Related Development Index (GDI)}

This measures differences in achievements between men and women for the four following indices:

- life expectancy at birth

- educational attainment

- share of total population

- share of economically active population 
- The GDI for Sierra Leone in 2001 according to the UNDP Human Development Report is 0.3573

- This shows that Sierra Leonean women suffer from greater deprivation and lower achievement levels than men.

- Except for LEB and share of total population, women lag behind in all other aspects, especially education - female literacy of $19.1 \%$ is half of that of male which is $38.7 \%$ (Government of Sierra Leone, 2001) - and economic activities. In the light of other factors (socio-economic, political, etc.) the war has only aggravated the situation.

\section{Gender Empowerment Measure}

This captures gender inequality in major areas of the economy. These include economic, political participation and decision making. It focuses on women's opportunities rather than their capabilities.

- Like the GDI the GEM calculated for Sierra Leone in 2001 is 0.3293 showing a big difference in women and men's opportunities in Sierra Leone.

- The low GEM in Sierra Leone is a course for concern.

\section{Moving towards an Alternative to Sustainable DeVElopment aNd TOWARDS GENDER EQUity IN SiERRA LEONE}

The issues discussed above highlight a serious equity problem in Sierra Leone. This calls for support for gender equality objectives because a failure to do so is a vital injustice. Positive measures must be taken to rectify disparities as an inherent part of the national development agenda. Equity implies creating and maintaining a balanced situation where disparities are acknowledged, understood, and addressed. Equitable development will remain elusive unless a concern for equity is present in all aspects of the development process, in the production, distribution, consumption and property rights. Gender analysis could be useful to shed light on these processes from the point of view of the gender relationships. 
Through gender analysis, governments and non-governmental organizations can become aware of the hidden processes that support and perpetuate disparities, and then be able to design and implement policies that either directly correct or, at least, seek not to exacerbate these imbalances. To address such disparities the following factors may serve as alternatives for sustainable development and gender equality.

\section{EDUCATION}

Sustainable empowerment of women is an ongoing process of individual and collective struggle to challenge the unequal power relations between men and women. There is an intimate connection between education and development. The concept of education is the process that enables women to come together to seek the knowledge and information, which can empower them to control and direct their own lives. As women become more aware of the complex web of factors that have deprived and marginalized them, they begin to identify the ability to read and write as a skill that can foster sustainable development and thus empowerment. Today, education for women is considered as an important tool for achieving equality between the sexes. Policy-makers in Sierra Leone have come to accept that sustainable development can come out of the education of women as a way to empower them. Several radio and television campaigns have been launched on the theme "send your girl child to school" while adult literacy programs are concurrently run.

\section{Employment through Micro CREDit}

Women in the informal sector usually set up a business of their own to earn money and become self-employed. To be able to start a small business these women are in great need of credit. The government has created group loans to poor people at low interest rates but these loans have mainly been accessible to group leaders, predominantly men. 
Micro-finance programs targeting women have become a major plank of the government's poverty alleviation strategies since the late 1990s. Consonant with the concern for financial sustainability, accumulating evidence of women's higher repayment rates has led many programs to target women. Increasing women's access to micro-finance provides economic empowerment, increased wellbeing for women and their families and wider social and political empowerment.

Conditions for micro-finance delivery affect women's ability to use micro-finance to increase and control incomes. For sustainable development purposes, though interest rates must cover cost of loan and delivery, they must be kept low, easily accessible, and the loan strategy must provide for graduation to larger loans; "multiple choice" options based on participatory consultation, including loans for new activities, health, education and housing should be encouraged.

\section{HeAlth SeRvices}

Reproductive health services provide men and women with the knowledge they need to protect their health and the health of their families. This includes family planning, methods to prevent and treat sexually transmitted diseases, including HIV/AIDS, and discourage harmful practices against women.

\section{ENVIRONMENT}

Sustainable development programs must foster an ecologically sound, economically viable, and socially just development. It must focus on blending gender issues into the global environmental movement by: strengthening national networking between women's and environmental groups; mobilizing women's involvement in environmental and sustainable development decision-making; and advocating for gender mainstreaming in national forums. Where the national environment and biodiversity are to be preserved, 
women should play the lead, for most of their economic activities entail tapping the natural resources.

\section{TRAINING}

Women are key actors in the food system at all stages, from production to processing to utilization. Training activities must reflect this reality. Extensive training for women is needed in the areas of agricultural production, post-production processing, small enterprise development and food preparation, as these are the economic activities women engage in; they are illiterate and do not qualify for jobs requiring some educational qualification. Trade (petty trading) has become a crucial step in the food system especially for the urban women who in most cases are single mothers catering for their families. Basic training in record keeping and business management will help empowering women.

\section{GOVERNANCE}

Good governance, the art of efficient public leadership, is the process by which authority is exercized in the management of a country's economic and social resources; and the capacity of governments to design, formulate, and implement policies and discharge functions.

Where good governance has been lacking, (be it economic, social or ecological) as was the case in Sierra Leone in late 1970s to early 1990 s, no progress was made. On the contrary it resulted in stagnation at an already low level, or even in economic reversals.

Poor governance generates a social environment detrimental to development. In such cases even external aid, whatever the amount or intention, has little effect. Indeed, it even becomes harmful, like in Sierra Leone where it contributed to prolonging an undesirable situation. 
Good governance places people at the center of development. Where people grow, profits grow. Where there is long-term investment in people's health and education, where both men and women, regardless of their social status, have access to the necessary means of production, extension and credits, they can take their fate in their own hands and use opportunities to improve their quality of life.

The responsibility for sustainable development at national level, involving the complexities of economic, social, political, cultural and ecological components that must be put together under a specific set of conditions, lies first and foremost in the political regime's hands.

\section{THE WAY FORWARD:}

\section{How Can the Gender Inequality Gap Be Closed IN SiERRA LEONE}

Four main approaches are discernible:

\section{Tackling Poverty}

- Research has shown that women are poorer than men and even among the poor in developing countries women predominate. There is therefore a very strong need for aid agencies to provide women with resources to help them cope with their poverty.

- Research has also shown that women give far greater proportion of whatever they earn to their children and families. Thus, channelling resources through them is arguably a very cost effective way of channelling resources indirectly to the family, children, older persons and to others in the community. 


\section{Redressing neglect}

- It is now widely recognized that women have largely been neglected by aid programmes and development planners. The vast majority of aid that goes to people is directed to the family which implies to men since they are the heads of the families.

- The assumption is that they will distribute benefit according to need. But considering that men and women have different needs, different concerns and different perceptions of life goals, and as men use a large proportion of family resources for their own purposes and tend to group that of the women with their children's, they have derived dispropotionate advantage of the modern education, training, land, credit they have received and reached positions of power. In contrast women have been left in a much weaker position than formerly.

- With this background, I think that it is necessary, for reasons of social justice and practicality, to give women direct support so as to redress the balance.

\section{Attitudinal change}

- One contributing element to women's lagging behing in Sierra Leone is the fact that many women lack self-esteem in a maledominated society and perceive themselves as unable to perform certain tasks or are discriminated against in hiring. Even educated women face this situation and consequently end up as nurses, secretaries and house wives.

- Gender inequality itself is greatly perpetuated by women themselves. It is mothers who over-feed sons and underfeed girls. It is mothers who take the girls out of school to ensure that boys remain there. In other words the question of how to change both women and men's attitudes has to be addressed so that women and girls get a fair share of social and familial resources. 


\section{Empowerment}

- In most communities in Sierra leone women are the main agents of change. Implicit in their strategy is an acceptance of change seen in a positive light. But Sierra Leone has been experiencing negative change, and women are often the first to protest against the destruction of communities, environment and lifestyles.

- Seeing women as central to the process of change overturns a common assumption that women are innately conservative and opposed to change. I would rather say that this approach assumes that women only resist change when they are not involved in planning or implementing it, have no control over any of the processes involved and are unlikely to benefit from it.

- Taken further, that unless women themsleves are empowered and feel they can influence the direction of change, and given structures through which they can be involved in the implementation and control of the process, they will not be enthusiastic change agents.

- However, once involved, the direction, modalities and pace of change will be more sustainable as both men and women support them. Implicit in this is the assumption that giving small power to individual or groups of women will not lead to a long term, sustainable change.

- What we need is a more strategic approach that includes working closely with women's groups as partners, providing them with information and contacts with other groups, facilitating networking between women's groups, identifying organizational needs, providing training and other support. 


\section{CONCLUSION}

\section{STRIVE FOR FINANCIAL SUSTAINABILITY}

- Develop credit programs for poor women with effective, informal lending practices including small, short-term loans increasing gradually in size;

- Quick, simple application; and management of nonpayment risk with group guarantee, savings and possibility of repeat loans.

\section{SERVICES}

- Provide services for women in their communities and in the economic activities they know - but improve productivity, profitability and working conditions.

- Improve women's status by organizing women's support groups outside the home.

- Help women fit their economic activities flexibly into roles of parenting and other household responsibilities.

\section{SOCIAL INTEGRATION}

- Integrate financial services with other benefits such as literacy, health, education, sanitation and environmental conservation, etc.

- In talking about women's situation in the light of economic development in Sierra Leone, it is very important to note that the country has gone through or is going through years of civil war. This is undisputably a very important factor for women's economic status. It is obvious that whatever the natural endowment of a country, a real human development cannot take place where bloody civil wars and desperate brawls over the allocation 
of scarce resources are raging and where despots bleed their countries dry to enrich themselves and arm their subordinates.

- It is impossible for an economy to flourish where the "power of the gun" rather than free and fair elections decides who shall rule. A government that shoulders responsibility for sustainable development and ensures its people enjoys security, solidarity, order and continuity, creates an environment in which citizens can exercise their productive, political and cultural abilities. The 10 years of civil conflict have put Sierra Leonean infrastructures and human development levels to the lowest in the world as noted in the Human Development Index. Regardless of that position, as peace returns, there is nothing better than a search for sustainable development alternatives with a gender face. 


\section{SOME ASPECTS OF THE IMPACT of Globalization ON GENDER IsSUES IN BULGARIA}

\section{Genoveva Tisheva ${ }^{1}$}

“... Countries undergoing transition have a unique political opportunity to improve the situation of women as an integral part of the successful transition to democracy and a true market economy. They can thereby avoid the entrenchment of structural discrimination and the need for further fundamental changes in the future...

from the Concluding Observations of the Committee on Elimination of Discrimination against Women to the Bulgarian government, February 1998

Did the Bulgarian government take this opportunity of market liberalization and increasing economic globalization? Or were the alarming trends confirmed?

The hardships of market liberalization and European Union membership exacerbate the need for social safeguards. The Bulgarian government must try to create a competitive environment while

1 Director of the Bulgarian Gender Research Foundation (see end of the book). Lawyer involved in protection of humam rights and women's rights, more specifically. 
protecting its citizens from the potential harms of free markets. In the last ten years of transition and structural reforms the Bulgarian government did not manage to counter the negative effects of globalization, specifically on women and the most vulnerable groups, through enhancing regulatory capacity and strengthening the safety nets. Reforms regarding privatization, employment conditions, social policy, migration, access to new technologies had a disproportionate negative effect on women. We will illustrate some of the aspects of the influence of globalization.

\section{ECONOMIC CONTEXT}

Prior to the democratic reforms the Bulgarian economy was characterized by a central planning system forcing development of heavy industry to the detriment of the consumer-led production and of the service sector; monopoly of state property and prohibition of private ownership of the means of production; state monopoly on foreign trade; specialization of the Bulgarian industry within the COMECON market.

The "emancipated woman" model was imposed through a variety of economic, legal and social mechanisms. Two parallel processes soon emerged: the development of legal underpinnings of gender equality and women's massive and equal inclusion in the labour force. For example the share of women in the labour force in Bulgaria in 1985 was $49,5 \%$.

After the political upheaval in 1989, Bulgaria launched radical economic reforms aimed at introducing market mechanisms. These reforms comprise the following main components: transition from centrally planned to market economy; adoption of a market oriented fiscal and monetary policy; restitution of the confiscated private property; privatization; agrarian reform; aspiration to integration into the European Union, NATO and the international economic community as a whole; promotion of foreign investments. The political changes in early 1997 were aimed at overcom- 
ing the economic crisis and at speeding the structural reform and the integration of Bulgaria into the European structures. The accession to the EU became a real obsession for the government. In view of the monetary stabilization of the country, in July 1997 a Currency Board was created.

The price of this policy was a restrictive taxation and social policy which caused a serious decrease in the income of the population. The economic environment seriously affects the labour force as unemployment, wage cuts, mass redundancies, violations of socialeconomic rights are widespread.

This is especially true for women who are disproportionately affected by the economic restructuring. Because of the inherited segregation of labour, lower opportunities and access to training and retraining, their heavy social burden - the care for the children and the family - as well as the social benefits related to their reproductive roles, women are less competitive in the labour market.

\section{THE IMPACT OF PRIVATIZATION}

Privatization is both one of the central economic policies of the Bulgarian government and a component of globalization. With the opening of the country to the EU - since 1995 Bulgaria has the status of an associated country and started negotiations with the EU in March 2000 - and to the foreign investments and markets - Bulgaria joined the WTO in 1996 -, the country is entering the global economy. The Bulgarian government was commanded by the international financial institutions for its strict implementation of structural reform and for the financial stabilization of the country. The privatization process, however, was notoriously corrupt and non-transparent. About $70 \%$ of the state assets (including banking) have been privatized. Because of corruption and inconsistent government economic policies, privatization has not strengthened the economy. 
In the 1998-1999 period the Bulgarian Gender Research Foundation conducted a sociological and legal research on the specific impact of privatization on the socio-economic rights of women. Here are some of the findings:

- Privatization affects the labour and social rights of citizens and of certain groups of women in particular. The privatization and restructuring processes are connected with negative attitudes of citizens because of the economic insecurity and the danger of job reductions and unemployment for those working in the stateowned sector, the need for readjusting to work in the private sector, the risk of non-respect of social and labor rights, especially in the private sector. Work without a labour contract or any contract at all is a widely spread phenomenon, which is also a violation of the right to social security and to unemployment benefits. The amounts of the social security allowances (especially during maternity leave) and unemployment benefits are low and they can not constitute a real guarantee, especially for certain vulnerable social groups, including women. They are more vulnerable in the dynamic of the labour process - in seeking jobs, redundancies, long-term unemployment. The rights of workers and women above the age of 35-40, for whom it is extremely difficult to find professional realization after dismissal from the state sector, are threatened. Foreign investors in Bulgaria require state restriction of guarantees for labour and social rights in the transition to market economy, which as well endangers women and their so-called "privileges" such as extended maternity and child care leave. Some foreign investors, especially from Greece and Turkey who are at the end of the subcontracting chains in the garment industry take advantage of the cheap labour force and lowered labour standards.

- In addition state control for violations of labour and social rights have decreased. The trust in trade unions as defenders of the workers in the process of privatization has dropped. The Labor Inspection and trade unions have the power to, but do not suffi- 
ciently protect labour rights. It is established that they are not effective in monitoring discriminatory practices and providing defense for women.

- Women, especially young women, women during and after maternity leave, women with small children and women over 40 , are disproportionately affected by the privatization and restructuring reforms. The research revealed the existence of discriminatory practices in the recruitment process - women are very often asked additional questions not connected with their professional qualification: about their availability, their family and personal obligations. On top of all this sexual harassment in the workplace emerged as a serious problem.

- There is a lack of adequate state policy for women in the process of economic restructuring and in the labour market. There is a lack of public affirmative action ensuring equal participation of women as a work force and as active participants, namely in entrepreneurship. In the 2000-2001 period under the pressure of the European union, of women's NGOs and of the Beijing +5 process, the Ministry of Labour and Social policy elaborated a draft Equal Opportunities Act. Although elaborated with a large consensus between government and civil society, the Act was rejected by the parliament last fall. Thus, the institutions openly declared their unwillingness to regulate the area of gender discrimination in the labour market.

\section{SOCIAL CONTEXT}

Evidence of the contradictions between declared successful economic development and low social standards multiplied in Bulgaria in 2000 and 2001. In mid-2001 the discrepancy between promises and reality led to changes in the parliament and the government. A new political force, led by former King Simeon of Bulgaria, acceded to power with new social promises. What was the situation? 
Despite a registered growth in GDP of $4 \%$ in 2000 (compared with $-7 \%$ in $1997,3.5 \%$ in 1998 and $2.4 \%$ in $1999^{2}$ ) Bulgaria's average GDP currently is only $22 \%$ of EU countries. With a per capita GDP of US\$1,500 and average income of US\$ 120 in 2000, Bulgaria lags far behind EU countries, which have per capita GDPs above US\$22,000. It also lags behind the more advanced former socialist countries with per capita GDPs of US\$3,5003. An additional problem is Bulgaria's foreign debt, which amounts to more than $80 \%$ of its GDP. The discrepancy between economic growth and living standards in Bulgaria was aggravated by US\$ 80 million extra losses and damages resulting from the Kosovo crisis. The enduring tension in the region continue to challenge and jeopardize a successful and rapid accession to the EU.

After 10 years of economic restructuring, it has become clear that Bulgarian governments cannot cope with the problem of poverty. The poverty coefficient in Bulgaria (percentage of people living on less than US $\$ 1$ /day) was $12.1 \%$ for 1999 , slightly lower than the $199813.1 \%^{4}$. The poverty coefficient as percentage of households living below the unofficial poverty line of less than US\$23/person/month in 1999 was still as high as $16.53 \%{ }^{5}$. The majority of retired people are socially excluded, with an average pension of less than US\$33/month in 2000.

A guaranteed minimum salary is fixed in Bulgaria by the Council of Ministers. It is currently about US\$ 50 /month, far below the subsistence minimum.

By the end of 2000, one of the major social development indicators, unemployment, stood at $18 \%{ }^{6}$ ! This represents a considerable

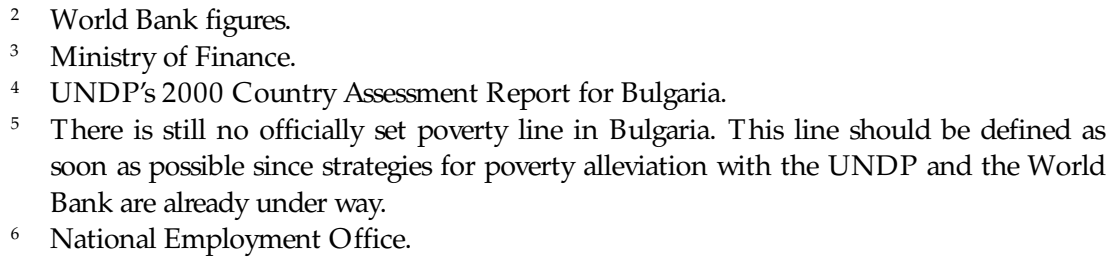


increase and continuation of a steady trend from previous years - $11 \%$ in $1995,12.3 \%$ in $1996,12 \%$ in 1998 , etc. A more realistic rate of $27 \%$ is obtained by adding the estimated percentage of unregistered unemployment. Registered unemployment rates of $30-35 \%$ in some regions are far higher than in Sofia, where the rate is $4.47 \%$. Women prevail among the unemployed $(52.6 \%$ by the end of 2000). Because of strict requirements for entitlement and a short period of coverage, only $28 \%$ of the registered unemployed persons receive unemployment benefits.

The new government is strongly committed to curbing unemployment, the official rate being already above $19 \%$ at the end of 2001 - one of the highest rates, if not the highest, in the Central and Eastern Europe countries.

Despite these intentions, the first measures aimed at boosting employment brought to serious cuts in the unemployment benefits. Employees contribution to social security in Bulgaria are the highest in Eastern Europe, reaching 39.2\% of gross income for most workers. This places a heavy burden on workers, impedes employment and creates inequalities. Poverty and unemployment push people into the informal economy. Although no official data are available, it is estimated at about one-third of the economy. Women are here again disproportionately affected: they bear the "burden" of the social benefits related to maternity and child care, and they have to cope with hardship in the family and take any job.

\section{The Role of the BRetton WoOds Institutions}

A draft memorandum was approved in December 2001 for a twoyear stand-by agreement worth US\$ 300 million between Bulgaria and the International Monetary Fund. It is the latest in a series of agreements with the IMF in the last decade, purportedly aimed at stabilizing the country's economy. The recent agreement focuses on key policies the Bulgarian government should follow: reduce the 
vulnerability of the state in respect to current and future changes in the world economy; keep the Currency Board agreement stable; and reduce the foreign debt/GDP ratio. These goals are to be achieved through further liberalization, especially in the energy sector. The IMF required the setting of a long-term pricing policy, privatization of energy distribution and market liberalization by early 2002. The agreement requires not only financial stabilization, but also boosting the competitiveness of the Bulgarian economy and solving social problems.

Although the concrete parameters of the final memorandum will not be made public until the first quarter of 2002 and despite the lack of opportunities for public participation in the negotiating process, it is obvious that the government has had to make many concessions. Many positive social promises made in the pre-election and post-election periods (national elections were held in June 2001 and the new government came into office in July) were blown down by the conditions imposed by the IMF. The declared "people-centred" governmental programme is about to fail. A striking example of the eagerness of the government to please the IMF was the decision to increase by $10 \%$ the consumer price of electrical power and heat starting in October 2001. The decision was made in violation of the law, without consulting the trade unions, and was recently reversed by a decision of the Supreme Administrative Court. This tough measure, still deemed necessary despite the court decision, obviously impacts the already low living standard of the population as a whole. It obviously affects women disproportionately, since they are the first to feel the effect of increasing consumer prices, and as there are many single mothers heads of families.

Another result of the interference of the international financial institutions is the lack of a consistent social policy by the government. Family policy, for example, is a key feature of democratic governments and a major indicator of a good standard of living. The recently approved targeted family allowances system illustrates the Bulgarian reality. The already extremely poor allowance of less 
than US\$ 5 per child per month - one of the lowest among Central and Eastern European countries - was doubled, but from January 2002 it will be allocated only to families with incomes of slightly above US\$ 70 per capita. According to the estimates, three times fewer children will benefit from the allowances than before, yet this measure will be assessed as effective for poverty alleviation in Bulgaria. This change, strongly recommended by the World Bank as a condition for receiving loans for poverty alleviation, has been pending for more than two years. Yet there has been no real public debate on this issue. This recent decision will again have a more negative impact on women.

This is only an illustration of the targeted approach endorsed by the international financial institutions and imposed on governmental social policy as a whole. It is not accidental that the whole social programme of the Bulgarian government, full of good intentions, is deprived of real, consistent and long-term elements, the focus being put on social assistance only. This, not surprisingly, is in compliance with the draft Country Assistance Strategy (CAS) of the World Bank. Although the proposed CAS is open for national discussion, it contains core directions that must be followed regardless of what comes out of the consultation process. Here again the main theme is the targeted approach; without taking pervasive poverty into account, the measures are focused on specific groups of the population only and the proposed solutions are based on redistribution. It is shocking that poverty in Bulgaria is still widespread: according to the most recent data from trade unions, about $38 \%$ of the population receive less than BGL 100 (US\$ 50) per month.

The appeal of the international financial institutions was to speed up privatization, and it was implemented, though at the price of widespread corruption. The restructuring of the health and education systems, performed with loans from the World Bank, illustrates the adverse effect of the assistance of the financial institutions on the social sphere and the human resources in these sectors. These sectors, although in need of improvement and modernization, were 
subjected to fundamental changes that practically liquidated the positive and competitive elements they possessed. Furthermore, dramatic shifts occurred in the related labour force, which was 70$80 \%$ female. In this case, as in other instances of restructuring and privatization, the reforms had gender implications, if not a clearly disproportionate gender impact. The human side of the reforms have not been taken into account by the international institutions or considered sufficiently by the government, despite the recommendation of the UN Committee on Economic, Social and Cultural Rights in December 1999 that the Bulgarian government "in the course of the negotiations with the international financial insti tutions... bear in mind its obligations to respect, protect and fulfil the rights set forth in the Covenant."

In the meantime, with an average monthly salary of US\$ 115 (according to the most recent data of the World Bank), Bulgaria lags behind other EU candidate countries from the Central Eastern European region (US\$ 270 in Latvia and Lithuania and US\$ 151 in Romania). In the last report of the European Commission on the progress of Bulgaria towards accession, the country was found once again not in compliance with the EU economic criteria. After years of negotiations with the Bretton Woods institutions for economic liberalization, the EU did not find a functioning market economy in Bulgaria! The slogan "financial stability" has only brought about more poverty.

If Bulgaria is to emerge from endless economic transition, the government should take a position on national economic development independent of reforms imposed by international institutions. The process of the EU accession should be used for improving the social standards. This requires from the government more transparency in all internal and external economic decision-making and increased access for civil society in the decision-making process. Women and women's organizations should be important participants in this process. 


\title{
MUJERES PIQUETERAS: EL CASO DE ARGENTINA ${ }^{1}$
}

\author{
Isabel Rauber ${ }^{2}$
}

\section{INTRODUCCIÓN}

Hablar de Argentina, de mujeres piqueteras, recuerda de inmediato las imágenes grabadas en nuestras retinas en las últimas semanas: mujeres con sus niños en brazos o en cochecitos cerrando el paso en los cortes de rutas, recorriendo las calles y avenidas, mujeres buscando algún alimento desechado por las puertas traseras de restaurantes y comedores, mujeres cuidando el hogar mientras el esposo lucha, jóvenes casi niñas haciéndose cargo de sus hermanitos para que la madre salga a trabajar hasta que el padre - si está - regrese a casa, niñas deambulando por las calles, prostituyéndose junto a sus hermanos o amigos para conseguir algo de comer o inhalando pegamento para aturdirse y olvidarse del hambre y el desamparo, mujeres organizando las carpas y las ollas populares en los piquetes, mujeres luchando en las barricadas en los días de diciembre último, rompiendo los moldes y las predicciones, protagonizando su destino.

1 Extractos de esta ponencia fueron traducidos en frances en Christine Verschuur (dir.) avec Fenneke Reysoo, Genre, mondialisation et pauvreté, Cahiers Genre et Développement, no 3, Genève: iuéd-efi; Paris: L’Harmattan, 2002, 255 p., pp. 159-165.

2 Directora de Pasado y Presente xxI. Profesora adjunta de la Facultad de Filosofía de la Universidad de La Habana. Investigadora social, especialista en cuestiones de género y participación social desde abajo. Miembra del Consejo Científico Asesor de la Central de Trabajadores de Cuba (CTC). 
Esta realidad conduce de inmediato nuestros análisis a la revisiónactualización de los nexos existentes entre género, pobreza y poder (de opresión y discriminación, de subversión de lo establecido, de transformación del actual estado de cosas y de las relaciones entre hombres y mujeres que lo sustentan).

Como es conocido, género y pobreza son conceptos de significación múltiple cuyos sentidos se entretejen formando una tela compleja. El concepto de género ${ }^{3}$ alude a categorías histórico-sociales, económicas y culturales atribuidas - por ese medio - a los sexos varón y mujer, que regulan las relaciones sociales, económicas y familiares entre ambos y permiten una clara delimitación de espacios de poder entre ellos, y de acceso o no al mismo. El concepto de pobres y pobreza, resulta aún más complejo cuando buscamos penetrar y rescatar a través de ellos no sólo las condiciones objetivas sino las vivencias cotidianas de hombres y mujeres concretos, y el conjunto de sus relaciones familiares, económicas, sociales y políticas, generadoras a su vez de realidades en continuo cambio e interpenetración unas con otras.

En condiciones de exclusión social, pobreza y género se entremezclan, dotando de múltiples sentidos a las acciones que hombres y mujeres realizan para enfrentar la situación impuesta por la guerra de sobrevivencia, a la par que tornan más complejo cualquier debate

\footnotetext{
Cuando hablamos de género suponemos una interrelación social entre hombres y mujeres. Estas no pueden dejar de lado al varón en la búsqueda de una identidad que viene marcada por su relación con él. De la misma manera que aquél no puede dejar de prestarle atención a ella. En los barrios es un elemento crucial, los dos forman un continuo que configura una existencia en la que se implementa una repartición de tareas, obligaciones y derechos. Entre uno y otro construyen su cotidianidad en diálogo permanente, cuyas raíces se insertan dentro de una tradición cultural más allá de nuestra propia memoria: el patriarcado. En este sentido, al abordar la problemática de la globalización en las mujeres del tercer mundo, es decir, en condiciones de una pobreza generada por el saqueo y la exclusión creciente, su impacto debe ser visto también desde esa articulación generada entre mujeres y hombres. Esto permitirá observar los elementos en relación con los otros factores que dan sentido a cada uno de ellos a través de mediaciones e intercondicionamientos, no siempre posibles de identificar y plasmar teóricamente.
} 
sobre las alternativas posibles, particularmente, en el plano de las relaciones sociales-familiares, hombre-mujer.

Los roles, valores y patrones de conducta, han estallado junto con la desocupación, con el abandono del Estado de su responsabilidad social para con sus ciudadanos, el chantaje por migajas de pan, la desnaturalización de la familia y las responsabilidades de cada cual. El concepto de niñez estalla frente al final de la infancia, la ilusión queda atrapada en algún riel de metro de la ciudad, la inocencia se transforma en privilegio de las clases minoritarias del poder, y el amor se vuelve pecado, manchado por el fango de las callecitas de los barrios más humildes o el improvisado piso de tierra de las casuchas de las villas miserias.

Ensañándose en la pobreza que crea y recrea pobres, y en los pobres mismos, el poder ensaya su crueldad a modo de camino a su eternidad, luego la extenderá a la sociedad toda. En este sentido, cada vez que un hombre desocupado golpea a su mujer o a sus hijos, cada vez que la mujer soporta el golpe y luego lo reproduce descargándolo sobre sus hijos, el poder triunfa: desvía la violencia hacia las asimetrías de género y al interior de la familia, enfrentando pobres contra pobres, cuestión que celosamente - como canal de desagüe - ha venido produciéndose y reproduciéndose durante miles de años. Así, poder y patriarcalismo se dan la mano con la pretensión de salir ilesos, pero no les será fácil. En medio de tanta miseria - también de valores humanos - hay muchos hombres que luchan, que buscan una salida para ellos y sus familias, y hay muchas, muchísimas mujeres que, impulsadas por la defensa de sus hijos e hijas, son capaces de levantarse, salir de sus casas y pelear por la vida aún desde abajo del punto cero.

La guerra por la sobrevivencia lo invade todo e impone sus pautas al mundo de la desocupación y al del trabajo. Hoy, ir a trabajar significa incorporarse a la guerra de uno contra los otros, los enemigos, que - según esa lógica - terminan siendo todos. La primera batalla para la mujer es dejar solos a sus hijos, salir de casa y llegar 
al trabajo o a la ciudad en su busca. Luego de agotadoras jornadas, de abusos de patrones y capataces y con un peso en el bolsillo, viene la segunda batalla: volver a la casa, encontrar a sus hijos, al marido - si lo tiene -, y seguir batallando hasta volver a empezar al día siguiente.

\section{LOS PIQUETES: SURGIMIENTO}

Cuando parecía que la esperanza estaba a punto de perderse, cuando el horizonte se alejó tanto que estaba a punto de despeñarse desde su propia línea, cuando la vida parecía apagarse en el infierno de la muerte cotidiana, la mujer - defensora natural de la vida - revolviendo su historia y apelando a la fuerza de sus instintos más profundos y humanos, rompe los moldes culturales, traspasa las paredes de su ámbito culturalmente "natural" y sale a la calle, se hace piquetera, y con ella su familia (hijos e hijas, esposo). Negando la segregación social, se apropia del territorio que la excluye para gritar: ¡Estamos aquí, estos son nuestros hijos. Somos de carne y hueso, y tenemos derechos!

En ese proceso de participación, el piquete pasa a ser poco a poco el otro lugar de estancia femenina alternando con la vivienda y el barrio. "A nosotras no nos cuesta nada venir acá a pelear por nuestros hijos. Pero para un hombre que ha trabajado toda la vida es humi llante. Esta política los ha humillado como hombres" [Natalia, piquetera de La Matanza $\left.{ }^{4}\right]$.

¿Qué es el piquete? ¿quiénes son los piqueteros y las piqueteras? Indagando al respecto en diccionarios especializados de sociología puede encontrarse lo siguiente: "Persona o grupo que, participando en un conflicto obrero-patronal, trata de cerrar el paso a la salida o a la entrada de los locales del antiguo patrono. El piquete puede recurrir a diversas tácticas activas en la medida en que lo permita la ley, pero su

4 Distrito del Gran Buenos Aires con más de dos millones de habitantes. 
finalidad es perjudicar al patrono transgresor en su economía y en su reputación".

La fuerte irrupción de los piqueteros en la Argentina el siglo XXI, obliga a remontarse cuando menos a los inicios del siglo $x x$ y recorrer las luchas obreras de entonces. Analizando el desarrollo de determinados conflictos laborales y la conducta y los modos de organización obrera frente a éstos, muchas de ellas podrían considerarse como antecedentes genealógicos de la concepción, la organización y la forma de lucha piquetera actual. Al respecto, quizás el primer elemento significativo sea la procedencia obrera de muchos de sus actuales dirigentes, ahora precarizados laboralmente o simplemente desocupados. Sin embargo, los piquetes actuales son cualitativa y cuantitativamente diferentes a los anteriores, entre otras razones, por la masiva presencia de las mujeres en los mismos, aspecto al que dedicamos estas reflexiones.

Llevados a situaciones límites, piqueteros y piqueteras decidieron que era cuestión de vida o muerte exteriorizar su realidad, ponerla sobre el tapete, es decir, reclamando sus derechos en las calles y rutas del país, como un espejo de la sociedad que los expulsaba. En ese sentido, cada piquete se erige como una muralla o límite humano a la pobreza en su rostro de exclusión y desintegración social. De ahí la necesidad de cerrar el paso, cortar rutas, calles, denunciando con sus cuerpos la situación de virtual destierro en el que se encuentran en su propia tierra.

Destapando una Argentina desprolija, oculta y molesta para los medios y por los medios de comunicación, los piqueteros irrumpieron en la escena nacional hace poco más de cuatro años. En el presente, sus movilizaciones ocupan el centro de importantes conflictos sociales, a través de los cuales sus protagonistas han ido madurando en propuestas, organización y proyección.

Diccionario de Sociología, Fondo de Cultura Económica, México, 1987, p. 220. (Negritas de IR). 


\section{MOVIMIENTO PIQUETERO: EJES PRINCIPALES}

Los objetivos del movimiento piquetero - puede considerárselo como tal - son múltiples y se encuentran intercondicionados unos a otros. El centro de su quehacer es luchar por la sobrevivencia, conseguir trabajo o reivindicar el derecho a trabajar, reclamando la aplicación o ampliación de los llamados "Planes Trabajar" (suerte de paliativo de 120 pesos - equivalente a 120 USD hasta diciembre del 2001 - que el gobierno central y los gobiernos provinciales distribuyen mensualmente como sistema de ayuda de emergencia a los desocupados). En realidad, por la escasez de los mismos en relación a la demanda, su otorgamiento se transforma generalmente en instrumento de chantaje social y clientelismo político de los partidos que ocupan posiciones de gobierno, que los utilizan a través de sus caudillos políticos, como premio o castigo a la fidelidad o infidelidad de los "desdichados".

Para enfrentar todo ello, los piqueteros se organizan y el corte de ruta - como mecanismo de denuncia del fraude y la exclusión - pasa a ser fundamental, para asentar su resistencia y reclamos por toda la Nación, para atraer la atención de los medios masivos de comunicación y hacer saber al pueblo argentino que ellos existen, y para reclamar alimentos y "Planes Trabajar".

Luego de casi tres años de presencia sistemática en las rutas del país, en el año 2001 el piqueterismo se desarrolla vertiginosamente al ritmo del agravamiento de la situación del país. Se multiplican los cortes de ruta y sus protagonistas, se confluye hacia la realización del primer y segundo congreso nacional de organizaciones piqueteras y, consecuentemente, se constituye el movimiento piquetero. Simultáneamente se radicalizan los contenidos de sus luchas, avanzando hacia una estrategia ofensiva, como lo señala Luis D'elía uno de sus máximos representantes: "ya no pedimos sólo planes y alimen tos, pedimos trabajo y el fin de la represión, pedimos el fin del modelo neoliberal que responde a la globalización. Por ejemplo, el común deno minador que cruza a todos los compañeros del piquete son dos cuestiones 
macro: el tema de la deuda externa - no pagarla - yel de la concen tración de la riquezas".

\section{LAS MUJERES: PRESENCIA CLAVE EN LOS PIQUETES}

Desde el primer momento, desde los primeros piquetes y hasta hoy, la presencia de las mujeres - y de sus hijos - en los piquetes es fundamental. Determinadas a no volver a sus casas con los brazos vacíos y sin nada para "poner en la olla", las mujeres van a los piquetes a defender la vida con uñas y dientes. Decididas a lograr los objetivos propuestos, se incorporan desde el inicio y garantizan protagónicamente la instalación y la vida diaria en los cortes, que frecuentemente duran más de una jornada. Si hay que armar las carpas para instalar campamentos, hacer guardias rotativas, contribuir con la preparación de los alimentos - junto con los hombres, claro -, hacer las barricadas y quedarse en ellas para defender las posiciones tomadas, allí están las mujeres.

\section{Las Madres de Plaza de Mayo: Piqueteras mayores}

La historia arroja muchos ejemplos de participación de las mujeres en las luchas, y aunque no es posible ahora ahondar en detalles, sí vale recordar presencias y determinaciones emblemáticas para la resistencia a la globalización neoliberal y su manto de muerte, desocupación y exterminio. Cuando empezaba a instalarse para configurar el país que ahora exhibe como trofeo, el neoliberalismo - de la mano del imperialismo norteamericano y sus asesores militares - no dudó en recurrir a la dictadura militar más sangrienta de la historia nacional del siglo XX: el genocidio de los opositores - en su mayoría jóvenes fue el instrumento utilizado para implantar mediante el terror el modelo de hoy vigente. En esas condiciones, cuando el mismo infierno parecía adueñarse de la vida de los argentinos, fueron mujeres las que, traspasando el miedo, salieron a la calle en defensa de sus hijos, de la vida, enfrentándose cada jueves al poder dictatorial. 
Las Madres de Plaza de Mayo no retrocedieron nunca. Con los pañuelos blancos atados en sus cabezas como símbolo de los pañales de sus hijos, se concentraron y siguen concentrándose hasta hoy, cada jueves en la Plaza de Mayo para reclamar la aparición con vida de sus hijos desaparecidos. Ellas son las primeras piqueteras, las que formaron el primer piquete por la vida, enfrentando - con un coraje sin límites - al neoliberalismo genocida que llegaba tras la espada mortal de la dictadura militar del 76. Y lo siguen enfrentando hoy, cuando ya globalizado, continúa implantando - mediante el terror a la desocupación y la exclusión - el genocidio por planificación económica de la desigualdad. Ellas son las primeras piqueteras continentales en defensa de la vida, ejemplo de resistencia y lucha, de entrega y valentía. Por lo tanto, son parte de las luchas actuales. A tal punto llega su vigencia que el día 20 de diciembre del 2001, realizando su tradicional marcha de los jueves como desde hace más de 25 años, fueron brutalmente reprimidas. La Plaza de Mayo enardecía de indignación por todos su ángulos, las imágenes replicaban en los televisores, hombres y mujeres argentinos veían incrédulos la golpiza inexplicable y la soberbia descarada que desde la sala de un gobernante autista se decretaba el estado de sitio, con la ridícula pretensión de acorralar nuevamente mediante el miedo a todo un pueblo. La fuerza de la presencia de las madres, nuevamente llamó a la defensa de la vida. En pocas horas, la Plaza se convertía en un multitudinario piquete de un pueblo que iba por la renuncia del presidente.

\section{LAS MUJERES: "ALMA DEL PIQUETE"}

La presencia protagónica de las mujeres en los piquetes lo transforma todo. En primer lugar porque los piqueteros surgen de barrios populares, de asentamientos que alguna vez fueron morada de trabajadores o fueron invadidos por sus actuales pobladores -en gran proporción emigrantes del interior en busca de trabajo y un lugar donde vivir -, y allí, en los barrios, la mujer es una dirigente casi "natural". Como lo reconocen los propios piqueteros, las mujeres, al incorporarse a los piquetes, han impregnado en estas luchas una profunda emocionalidad, las han impregnado de sentimientos, 
de emotividad y pasión, y todo esto se traduce en fuerza. No digo que los hombres no lo hagan, pero por su propia cultura tienden a ocultar estos componentes omnipresentes en todo acto humano, a disfrazarlos y cubrirlos de racionalidades que no pocas veces oscurecen el camino de la vida, de la realidad, de las relaciones entre los seres humanos, de la verdad. Tradicionalmente estas cualidades han sido y aún son frecuentemente descalificadas como "debilidades" propias de las mujeres, pero poco a poco éstas se van imponiendo como un caudal de subjetividad, de coraje y entrega que enriquece y fortalece las luchas, integrándolas en otra dimensión, la de la familia, la de los hijos, la de la vida.

En otro plano, y simultáneamente, las mujeres resultan articuladoras naturales entre lo cotidiano y lo estratégico; entre el mundo privado y el mundo público, la familia, el barrio y la sociedad, la sobrevivencia, el mundo laboral y el poder. Como acota uno de lo los dirigentes piqueteros nacionales: "Su presencia es vital, porque todo empieza en la vida cotidiana y después se traduce en términos políticos. Y donde no hay coti dianidad, no hay organización, y donde no hay organización, no hay política". Esto se manifiesta claramente en la vida de los piquetes, particularmente en aquellos de larga duración y amplia participación de la población. Allí se producen verdaderas acampadas masivas, se instalan las carpas donde vivirán las familias y se organiza la vida en el piquete como si fuera un barrio. En este sentido, los ejemplos más relevantes son los cortes de La Matanza, a fines del 2000 y primer cuatrimestre del 2001 en adelante. Fueron varios días de permanencia, impactaron no sólo por la multitudinaria concurrencia y participación de la población, particularmente de las mujeres y los niños, sino también por la organización interna y la contundencia de sus reclamos y propuestas. Entre febrero y mayo del 2001 se producen en esa zona varios cortes masivos sobre la ruta 3 , dos de ellos de larga duración (9 días en febrero y 18 en mayo). En cada uno de ellos la vida comunitaria se reproduce y se recrea, es decir, se transforma, y para ello, la participación de las mujeres resulta fundamental. Las mujeres participan en todo, desde la base hasta la dirección, desde la defensa hasta la organización interna de su carpa. Una tarea funda- 
mental, es la de preparar comida en grandes ollas populares para miles de personas, además de reunir previamente los alimentos, tarea prioritaria en esos días. Esto es muy valorado, para entenderlo es importante tener presente que estamos hablando de sectores excluidos que dedican gran parte de sus esfuerzos y luchas a conseguir alimentos. Para ellos, el sólo hecho de comer caliente a diario es una razón suficiente para participar en un piquete. Para lograrlo, la mano de la mujer es clave, así como para garantizar la sanidad interna, las guarderías infantiles y el normal funcionamiento de la vida en comunidad. Ellas son las que organizan la familia y el barrio, también las organizadoras vitales de los piquetes.

A esto hay que sumarle la característica que dicha práctica comunitaria y femenina incorpora a la vida piquetera: abnegación y entrega sin limites aunadas a una flexibilidad, horizontalidad y construcción participativa. La mujer se entrega a fondo, se incorpora con la familia, con sus hijos, en primer lugar porque no tiene otras posibilidades y en segundo porque lucha para ellos, por ellos y, por tanto, con ellos. La sobrevivencia es un asunto de todos, por eso una vez que la mujer se integra, no tiene vuelta atrás. A diferencia de lo que ocurría en una familia media argentina en los años 70, recuerdo la gran naturalidad con el que una madre piquetera hablaba con sus hijos acerca de la importancia de su participación en los cortes, lejos de desalentarlos o hacerles desistir de su participación, lejos de pedirles que se queden en la casa y que "se cuiden", les explicaba cómo hacerlo mejor.

Vinculado a ello, puede afirmarse que en los piquetes y barrios piqueteros se está gestando un nuevo tipo de organización sociopolítica, un nuevo tipo de militancia, una nueva ética, una nueva mística. Según lo refirieron los y las piqueteras, a diferencia de los militantes partidarios que acarrean al movimiento social sus prácticas vanguardistas y ejecutan resoluciones previamente tomadas, en los piquetes se imponen prácticas más abiertas. Y esto tiene que ver con la presencia de las mujeres, acostumbradas a moverse más en lo territorial, en el vecindario, a lidiar - a diferencia de la fábrica - con lo 
cotidiano: convocan, llaman a la participación, diseñan colectivamente y, sobre esa base, van hacia adelante sin detenerse. Esto también ha sido y es parte de un aprendizaje, en donde la mujer aporta mucho, a la vez que descubre nuevos espacios, por ejemplo en el terreno de la solidaridad: "Nunca se me había dado esto de ayudarnos entre todos - reflexiona Marta, dirigenta piquetera -, ni siquiera con mis hermanos. Siempre creí que la dignidad era conseguir todo por mí misma sin mirar al costado. Ahora pienso que si no estamos juntos pronto ni siquiera vamos a estar".

La presencia de la mujer no se agota en el barrio ni en el piquete como tal, ella ha participado y sigue participando en todos los espacios, en las manifestaciones, en los cacerolazos, en las luchas por la salud, la educación. Basta recordar la heroica participación de las mujeres en la Carpa Blanca docente, instalada por más de dos años frente al Congreso nacional. Participan en las luchas sindicales, en las huelgas, incluso en conflictos gremiales en los que la mayoría son trabajadores hombres, las mujeres refuerzan la lucha con su presencia, dan ánimo y fortaleza. En este sentido, es muy importante referir también su presencia protagónica encabezando las marchas - caminatas de kilómetros y kilómetros durante más de 10, 12 horas - hasta la ciudad de Buenos Aires, hasta las puertas del Ministerio de Trabajo o hasta la Casa de Gobierno, concentrándose en la histórica Plaza de Mayo. Allí van ellas, abuelas, jóvenes, obreras, docentes, enfermeras, desocupadas, amas de casa, acompañadas por sus niños de pecho, en brazos o en cochecitos, caminando los que son un poco más grandes, con responsabilidades los que se acercan a la adolescencia y los ya adolescentes, conscientes de que la lucha por la vida, por el futuro, les pertenece a todos. Con su presencia, las mujeres y los niños hacen de los piquetes y sus marchas un acontecimiento de la vida familiar, conmueven a la opinión pública mal-influida por los comunicados oficiales y enfrentando a la represión, se abren paso hacia los objetivos propuestos.

Las mujeres no siempre conmueven a todos, frecuentemente pagan costos muy altos por su participación en las luchas, son desacredita- 
das, consideradas malas mujeres, malas madres o malas esposas. Recuerdo por ejemplo en los sucesos del 20 de mayo en la Plaza de Mayo, entre las primeras imágenes televisadas de las embestidas de la policía contra la multitud, a una mujer flaca y desgreñada, abrazada a su dos hijos pequeños, gritando sin retroceder, mientras recibía palos y más palos. La periodista que cubría el suceso - a todas luces de una situación social muy diferente a la de aquella mujer - en vez de condenar la brutal e injusta golpiza, y de la mano de los criterios patriarcales del poder, condenó a la mujer en cuestión: "Se puede entender la necesidad, dijo, pero no que usen a los hijos para eso". La periodista no es capaz de ponerse en el lugar de aquella mujer que, entre soportar que sus hijos lloren de hambre o deambulen por los basurales sin futuro, sale a luchar con ellos en busca de posibles soluciones, aun con el riesgo de tener que enfrentar a la represión. La mujer flaca y desgreñada está clara, lucha por la vida con la fuerza de la vida misma: sus hijos, entre otras cosas porque - obviamente no tienen una niñera para dejarlos en casa ${ }^{6}$.

\section{EL UNIVERSO DOMÉSTICO: CONCIENCIA CONTRADICTORIA}

Además del escarnio público, la represión y el cansancio físico que todo esto representa para ella y sus hijos, la mujer piquetera se enfrenta a una vida hogareña muy dura, marcada no pocas veces por la soledad o por la incomprensión del esposo, que con una frecuencia mayor a la imaginada, descarga sobre ella su violencia en incontrolado acto de impotencia frente al actual estado de cosas que no puede soportar ni transformar. Humillado en lo que - según su imaginario - es su condición masculina, que le dice que él es quien debe mantener a la familia, el hombre no acepta verse como - lo que a su entender considera - inferior a la mujer, y vuelca sobre

\footnotetext{
La pobreza no es aquí una abstracción, existe en la realidad de estos hombres y mujeres que reaccionan ante ella y la cuestionan a partir de los problemas que tienen. De ahí que para pensarla se requiera, además del saber adquirido en los libros y en las aulas, de la reflexión a partir del conjunto de las experiencias cotidianas de vida, que van a ir configurando una determinada realidad material-espiritual en los hombres, mujeres, niños, adolescentes y ancianos que la viven.
} 
ella su ira a modo de reafirmación de su superioridad, de ser el que manda, el que impone y al que hay que respetar. Si la mujer va a las reuniones del barrio o al piquete, en ocasiones recibe fuertes golpizas al ser descubierta por el esposo. Hablando acerca de esto un dirigente territorial comentaba: "Es muy difícil trabajar con María por que el marido es muy celoso y cree que viene conmigo y entonces le pega. Cada vez que le pega ella desaparece por semanas. Después vuelve, todos la respetan". En una movilización que se reclamaba alimentos, Marta, dirigenta piquetera, nos dice: "Si salgo en la tele, mi marido me mata", seguidamente, revelando su conciencia contradictoria, agrega: "Pobre, con una mujer guerrera como yo, es difícil conseguir trabajo".

Ocurre que las mujeres luchan, participan, se organizan y protagonizan su historia, pero todavía ven a la vida familiar y los roles allí adjudicados a hombres y mujeres como algo divorciado de lo social. No han logrado - no es algo que se logre individualmente ni al margen del diálogo con los hombres y de la participación en el propio proceso de transformación -, penetrar con fuerza el ámbito privado y los paradigmas de relación hombre mujer, y no sólo en lo que hace a la relación de ellas con sus maridos sino, en primer lugar, respecto a ellas mismas. Como lo señala María Angélica, 42 años, cuatro hijos: "Una piquetera tiene que poder con todo, en cualquier momentito voy a mi casa, lavo la ropa y limpio un poquito, pero sería lindo que mi marido me apoyara. El me tira la bronca [se enoja], pero se va a acostumbrar porque yo no lo abandono ni a él ni a mis hijos".

Las mujeres piqueteras no se incorporan a la lucha buscando la liberación de la mujer o la igualdad de oportunidades, no se reconocen a sí mismas como feministas, se incorporan a la lucha a partir del papel que les toca cumplir - entienden ellas - cuando el marido queda desempleado o abandona el hogar, con el paradigma de su identidad como madres y esposas. Muchas de ellas - al igual que las luchadoras de República Dominicana, de Brasil, de México y de otros lugares - añoran tener un marido que las atienda y las cuide, a ellas y a sus hijos. Es a partir de esta realidad causal acerca de su 
incorporación social y política, que puede producirse -y de hecho se produce - el crecimiento y desarrollo de la mujer como sujeto pleno de la transformación social.

Cuando las mujeres comienzan a sentirse más fuertes por estar organizadas y desde allí pueden resolver las cuestiones de supervivencia mínimas, empiezan a modificar su concepción acerca de lo que es la libertad, la solidaridad y el pensamiento propio. "Ahora nosotras estamos acá y estamos a la cabeza, eso antes no se daba, antes no tenía mos libertad de pensamiento". [Testimonio de mujer piquetera al cumplir 50 años en la carpa del piquete].

\section{DIRECCIÓN Y REPRESENTACIÓN :}

\section{ÁMBITOS PREDOMINANTEMENTE MASCULINOS}

En el plano de las direcciones máximas, tanto de las organizaciones piqueteras nacionales como del movimiento nacional piquetero, es necesario señalar que, a pesar de que se reconoce la importancia estratégica de las funciones desempeñadas por las mujeres piqueteras, del aporte de su mirada y sus reflexiones acerca de los problemas y las posibles soluciones, los máximos referentes nacionales reco nocidos son hombres. En general, las dirigentas piqueteras son reconocidas como tales sólo a nivel territorial. Para ratificar esta afirmación, basta una mirada sobre los principales actos nacionales con participación piquetera o analizar los nombres de las listas de oradores de los congresos piqueteros celebrados en el año 2001. Esto está dentro de la lógica cultural en la que se enmarca el empoderamiento y la participación femenina, en los movimientos sociales y políticos en la actualidad.

\section{A MODO DE CONCLUSIONES}

Todo lo expresado nos recuerda que la cuestión de género articula y atraviesa relaciones sociales de poder entre hombres y mujeres, y no es algo secundario ni secundarizable. Como ocurre también en este 
caso, las asimetrías de género se manifiestan en todos los espacios donde se construyen, disputen o ejerzan relaciones de poder entre hombres y mujeres. $Y$ esto es importante remarcarlo por dos razones. La primera, para no idealizar situaciones de pobreza, marginación o exclusión, como a veces suele hacerse desde el exterior de estas prácticas, pretendiendo que allí, per se, están resueltos todos los problemas -incluyendo los culturales propios de la estructura de dominación-; como si en el territorio, en las condiciones de pobreza y exclusión allí reinantes, pudiera crearse un espacio extraterrenal incontaminado - e incontaminable - por la cultura hegemónica de dominación y discriminación patriarcal. Y la segunda razón, para reafirmar la idea de que los mecanismos de dominación, que tienen sus raíces en la vida cotidiana y en el establecimiento de roles diferenciados y discriminatorios entre hombres y mujeres desde el interior de la vida familiar, están internalizados en las conciencias y en las prácticas de vida de todos y todas, mucho más de lo que a veces superficialmente suponemos cuando pensamos en los hombres y mujeres, sujetos de la transformación social; quizá porque queremos creerlo así, como para imaginar más sencillo el presente y el futuro, para aliviar falsamente nuestras tareas y responsabilidades críticas teóricas y prácticas.

Hoy, las condiciones para cuestionar el actual estado de exclusión y desigualdad impuesto por la globalización en Argentina, son inmensas y en estado creciente. A ello han contribuido las resistencias y las luchas de los trabajadores y trabajadoras, de los ocupados y desocupados articulados en el movimiento piquetero y a través de la Central de Trabajadores Argentinos (CT A), las luchas de los organismos de derechos humanos, de los jóvenes, de las mujeres, de las Madres.

El siglo XXI se inició marcado por el protagonismo piquetero que sacudió el país de norte a sur, reclamando el fin del modelo, justicia y equidad como base de la vida social. Como lo definió claramente Víctor de Gennaro -Secretario General de la CTA - mientras compartíamos una de las marchas piqueteras del 2001, la presencia per- 
manente del movimiento piquetero en las calles, conformó a su vez un gran movimiento pedagógico popular a escala nacional. Encabezado por mujeres -en los piquetes, en las barricadas, en el puente de Corrientes, en la Carpa Blanca, en la Marcha Grande, caminando hacia Plaza de Mayo una y otra vez -, este movimiento coadyuvó a la gestación del gran piquete nacional, el argentinazo del 20 de diciembre de 2001.

En este caso, vale detener la mirada en el instrumento principal de la protesta: las cacerolas (utensilios de cocina culturalmente femeninos). Esto es mucho más que un símbolo, expresa no sólo la presencia protagónica de las mujeres en tales jornadas, sino también que los cambios son más profundos, que llegan hasta la raíz de los ancestrales roles adjudicados histórica y culturalmente a hombres y mujeres. En este sentido entendemos las palabras de Cecilia Merchán, dirigenta de la CTA de Córdoba: "Las condiciones para discutir la relación de poder hombre-mujer se generan en las manos de las piqueteras que no temen cargar el machete para defender el corte de ruta, y en las manos de los desocupados que decidieron protestar con las cacerolas en las calles".

Consciente de que la transformación para ser verdadera debe abarcar a los propios hombres y mujeres que la protagonizan y la llevan adelante, insisto una y otra vez en la necesidad de interiorizar el proceso, de entender que si no nace de adentro, desde el interior de cada uno y de cada una, y no se proyecta desde allí y desde abajo - desde la raíz -, hacia el exterior: la familia, el vecindario, el barrio, la sociedad toda, no habrá transformación social posible. La transformación no está fuera de nosotras, sino dentro, busquemos sus puertas y entremos por ella, como las piqueteras, sin detenernos hasta lograr los objetivos propuestos.

Ponencia: "La participación de la mujer en la dirección del movimiento de resistencia. Posibilidades y obstáculos actuales", para presentarla al Foro Social Mundial 2002. Inédita. 


\section{Bibliografía}

Carrera, Nicolás Iñigo y Cotarelo, María Celia, “La protesta social en los '90. Aproximación a una periodización". En Revista PIMSA, No. IV, Buenos Aires, 2001.

Diccionario de Sociología, Fondo de Cultura Económica, México.

La tierra es nuestra. Hacia una política de Tierra, Vivienda y Hábitat. Publicación de la federación de Tierra, Vivienda y Hábitat (FTV), y del Instituto de Estudios y Formación de la CTA. Buenos Aires, 2000.

Merchán, Cecilia, "La participación de la mujer en la dirección del movimiento de resistencia. Posibilidades y obstáculos actuales".

Merklen, Denis, Asentamientos en La Matanza. La terquedad de lo nuestro. Catálogos, Buenos Aires, 1991.

Rauber, Isabel, investigaciones de terreno y entrevistas sobre esta temática, realizadas entre mayo y septiembre del año 2001. 


\title{
«PAS D'AVION, PAS D'ARGENT »
}

\author{
DES FEMMES RURALES FACE AUX RISQUES \\ DE LA MONDIALISATION (BURKINA FASO)
}

\begin{abstract}
Alexis Kabore $^{1}$
Les femmes maraîchères de Séguénéga, une commune rurale dans la province du Yatenga au nord au Burkina Faso, se croyaient peu concernées par cette histoire de la mondialisation. Elles se sont rendu compte du contraire après les événements du 11 septembre 2001.

Pour écouler leur production de haricots verts, les femmes passent par une ONG locale (le Groupement Naam) qui traite avec une coopérative nationale, l'Union des Coopératives du Burkina (UCODEB), qui à son tour exporte les produits en France. Après les attentats du 11 septembre 2001, Air France, qui assurait le transport, a suspendu le vol des cargos qu'elle affrétait spécialement pour le convoi des fruits et légumes depuis le Burkina. Alors les femmes se sont retrouvées désœuvrées cette saison, et donc sans revenus.

1 Etudiant en diplôme d'études supérieures à l'iuéd. Conseiller et coordinateur de projets.
\end{abstract}


Parce qu'elles ne peuvent pas compter sur le marché local: celui de la commune est trop faible pour absorber la production et les environs leur paraissent difficilement accessibles par manque de moyens de transport. Une des femmes résuma la situation: "Maintenant c'est grave: pas d'avion, pas d'argent». Il est apparu qu'il est plus facile aux femmes de vendre en France que dans les villages voisins.

Il y avait tellement d'intermédiaires locaux que la plupart de ces femmes ne percevaient pas leur dépendance vis-à-vis du contexte international. Par cet exemple nous aimerions interpeller les partenaires au développement pour que la tendance actuelle vers «les projets de développement local» n'oublient pas le global dans leurs discours et actions à l'intention des populations, même les plus rurales. 


\title{
GLOBALITÉ ET LOCALITÉS: LE CAS DE SA'A AU CAMEROUN
}

\author{
Marie-Pierre Essimi Nguina ${ }^{1}$
}

Le processus de la mondialisation des échanges économiques introduit bien des transformations dans les sociétés. Certaines d'entre elles passent presque inaperçues parce qu'elles sont très vite classées dans la normalité, au point de nous faire oublier qu'elles sont le résultat d'une construction sociale. Je pense particulièrement au sens donné à certains outils de travail ou encore à certaines cultures pratiquées en milieu rural. A SA'A, par exemple, il y a quelques années, le panier et la houe symbolisaient le travail de la femme, une pompe-pulvérisateur celui d'un homme. Il n'y a pas longtemps, cultiver la tomate ou le manioc était qualifié de féminin. Aujourd'hui, il en va autrement.

La société traditionnelle, qui faisait essentiellement des hommes des chasseurs et des pêcheurs, laissait aux femmes la responsabilité des plantations vivrières. Elles étaient les maîtresses des récoltes ${ }^{2}$ et les

1 Etudiante en diplôme d'études supérieures à l'iuéd. Directrice d'école au Cameroun, théologienne.

2 VINCENT Jeanne-Françoise, Tradition et transition, Col. L'Homme d'Outre-Mer, éd. Berger-LEVRAULT, Paris 1976, p. 10. 
responsables de l'économie familiale. Cette réalité montre une dépendance économique des hommes vis-à-vis des femmes.

La rencontre avec l'occupant occidental va introduire certaines modifications par l'adoption d'un autre système monétaire et surtout par l'introduction du cacao comme culture de rente. Ce qui précède nous ferait croire que les femmes en deviendront aussi des responsables en tant que spécialistes de l'agriculture. Au contraire, la culture de cacao alourdit l'activité des femmes pour qui le travail de récolte et de transport vient s'ajouter au travail vivrier ${ }^{3}$. Mais curieusement, le cacao introduit à SA'A vers les années 30 devient une culture masculine, transformant les chasseurs beti en paysans. Ils seront donc les bénéficiaires du changement économique apporté par cette culture de rente. Cette nouvelle construction de la société sera relativement maintenue à $\mathrm{SA}^{\prime} \mathrm{A}$ dans les années 60 à 70 . En plus du travail familial et domestique, les femmes s'occupaient de l'entretien, de la production vivrière et aidaient à la récolte du cacao dont s'occupaient les hommes. La division du travail entre les sexes était bien précise.

Comme culture pérenne, le cacao occupe l'espace et confère un droit de propriété. Elle apporte aussi un revenu monétaire. Très vite, les femmes vont dépendre économiquement des hommes. Il s'agit là d'un renversement de situation.

Mais, depuis les années 80 , notre culture de rente a perdu de sa valeur, en termes d'échange. De paysans planteurs de cacaoyers, les hommes vont devenir de plus en plus cultivateurs de produits vivriers. Les raisons de l'attraction de ce domaine jusqu'alors réservé aux femmes sont purement économiques. Les transformations sont ainsi remarquées jusque dans les représentations symboliques.

3 WEBER J., Types de surproduit et formes d'accumulation. La province cacaoyère du centresud Cameroun, in: Essais sur la reproduction de formations sociales dominées, O.R.S.T.O.M, Paris 1977, p. 73s. Cette étude montre aussi combien l'introduction de cette culture a favorisé la dépendance aux produits du marché et l'asservissement aux normes de ce dernier. 
Avant les années 80 , un panier trouvé au bord du chemin ou à un carrefour était signe de proximité féminine, ou tout du moins l'indice qu'une femme l'avait déposé. De même la vue d'une pompe pulvérisateur ou d'une brouette indiquait la présence masculine. Aujourd'hui, et ceci depuis les deux dernières décennies, le signifié de ces différentes représentations du travail agricole est devenu un pari car elles ne servent plus de repère. En effet, depuis la crise économique déclarée au Cameroun en 1986, il est difficile d'affirmer que le panier, la houe et les autres outils symbolisent le travail féminin ou masculin. Il en est de même pour certaines cultures dites féminines ou masculines, telles que la tomate, le manioc et le plantain. On serait tenté de parler de brouillage d'identité ou d'indifférenciation.

Cependant, une forme de stéréotype semble maintenue. Il y a lieu de reconnaître une houe utilisée par un homme. Elle a en général un manche plus épais ou plus long, et une lame plus large. Les paniers devenus de plus en plus volumineux servent à la commercialisation de la tomate. Leur volume rivalise avec celui du globe. Les plantations de tomates des hommes sont plus vastes. Les hommes disposent aussi de plus de temps pour s'occuper de leurs plantations de tomates, ils sont propriétaires de la terre. Un privilège dont ne jouissent pas encore les femmes à SA'A, bien que la loi camerounaise reconnaisse maintenant le droit d'héritage aux filles. Le poids de la culture et des coutumes est en effet plus considérable; les femmes restent donc exclues de la propriété foncière.

Cette petite analyse de la zone agricole de $\mathrm{SA}^{\prime} \mathrm{A}$ au Cameroun montre que la mondialisation des échanges économiques véhicule des transformations sociales. Toutes ces transformations déstabilisent les relations genre. 


\title{
DE LA DIVISION SEXUELLE DU TRAVAIL EN SUISSE: ENTRE CONFORMITÉ ET SOLUTION
}

\author{
Antonio Girardi ${ }^{1}$
}

\section{INTRODUCTION:}

\section{DIVISION INTERNATIONALE DU TRAVAIL ENTRE FEMMES}

Ce travail se propose de vérifier une hypothèse présentée par Federici dans son texte sur la lutte féministe dans un contexte de mondialisation économique ${ }^{2}$. L'auteur part de la division internationale du travail, dont le moteur serait constitué par l'accumulation capitaliste en faveur des habitants des métropoles, c'est-à-dire les

Etudiant en diplôme d'études supérieures à l'iuéd, économiste de formation.

2 Federici Silvia, Reproduction et lutte féministe dans la nouvelle division internationale $d u$ travail, 15 p. Pour la définition de mondialisation économique, je me réfère aux considérations dans Bertrand Maurice, «Les défis conceptuels de la mondialisation», Genève: iuéd, 1994, 14 p., p. 1. L'auteur soutient que toutes les théories sont d'accord sur l'évolution techno-économique qui entraîne la transformation de la société, tandis qu'elles divergent sur la description de ses dangers et ses désavantages d'après leur idéologie. Il envisage la nécessité de trouver une idéologie alternative, comme par exemple le néostructuralisme, pour une explication objective de la mondialisation qui débouche sur un nouveau paradigme. Pour les concepts utilisés, il me semble que l'approche de Federici s'y oriente sans abandonner l'analyse néomarxiste. 
pays les plus industrialisés. Cette division internationale du travail exerce une violence structurelle qui, en créant et en renforçant une division hiérarchique entre les femmes de ces pays et celles des pays du tiers-monde, empêcherait une lutte internationale commune d'émancipation de la femme. Bien que son analyse se concentre sur le transfert de la main-d'œuvre du Nord au Sud dans le secteur du travail de la reproduction sociale, Federici mentionne également le phénomène des femmes qui partent du tiers-monde vers les pays industrialisés où elles travaillent comme domestiques pour gagner de l'argent. Dans ces pays, il existerait une demande pour ce type d'emploi qui, selon l'auteur, aurait permis de résoudre le problème du travail ménager et de «libérer» des milliers de femmes des classes moyennes qui peuvent ainsi participer au marché du travail. Malgré le fait que les tâches ménagères restent une responsabilité des femmes occidentales, les domestiques leur permettent de se soustraire à un travail qu'elles ne veulent pas accomplir. La travailleuse domestique immigrée est souvent mal payée, éloignée de sa «vraie» famille, vivant dans une situation de solitude, soumise aux dangers d'exploitation liés à une position sociale et légale très vulnérable, d'abord en tant qu'immigrée et (de plus en plus) en tant que travailleuse sans papier ${ }^{3}$.

Cette nouvelle division hiérarchique entre les femmes du Nord et celles du Sud empêche de remettre en question le système d'exploitation des femmes au sein des ménages.

Mon travail entend vérifier l'hypothèse énoncée par Federici pour la situation actuelle en Suisse. A une esquisse descriptive des responsabilités au sein du ménage, succédera une analyse de la dimension symbolique, sociale et individuelle.

3 Neue Zürcher Zeitung (NZZ) Online, Der Preis für die Arbeit ist «ein Leben im Gefängnis», 16. Januar 2002. Sans-papier, ou clandestin, est le concept qui décrit les hommes et les femmes dont le séjour n'est pas réglé sous le point de vue du droit des étrangers: réfugiés qui ne quittent pas le pays, saisonniers qui restent sans permis, personnes qui n'ont jamais disposé de permis. 


\section{SUISSE: INÉGALITÉ DANS LA RÉPARTITION SEXUELLE DU TRAVAIL RÉMUNÉRÉ ET DOMESTIQUE ${ }^{4}$}

La répartition traditionnelle des responsabilités entre l'homme et la femme prévaut toujours dans les couples suisses. Pour $63 \%$ des hommes, l'activité professionnelle constitue l'activité principale contre $37 \%$ des femmes (graphique 1, page suivante). Dans $70 \%$ des couples et $90 \%$ des familles comptant des enfants de moins de 15 ans, c'est la femme qui assume principalement les tâches domestiques et familiales (graphique 2). Seulement un quart environ des femmes qui exercent une activité professionnelle à plein temps peuvent compter sur une contribution équitable de leur partenaire. L'éducation et les soins aux enfants, ainsi que les soins dispensés à d'autres membres du ménage, sont les tâches domestiques et familiales qui prennent le plus de temps (graphiques 3 et 4). Les femmes travaillent en moyenne deux fois plus pour le ménage et la famille (31 heures) que les hommes. Quel que soit leur âge, les hommes n'investissent en aucun cas davantage de temps dans les tâches domestiques et familiales que les femmes (graphique 5).

Les femmes, avec enfants de moins de 15 ans, accomplissent le plus de tâches domestiques et familiales ${ }^{5}$ (graphique 6): 52 heures par semaine contre 22 heures pour les hommes. Dans le même type de famille, les hommes exercent généralement une activité professionnelle à plein temps, tandis que les femmes sont souvent sans emploi ou employées à temps partiel, surtout lorsque les enfants sont en bas âge. Malgré une répartition peu équitable entre le travail domestique et l'activité professionnelle, les hommes et les femmes vivant

4 Ce chapitre descriptif se base sur les données dans Office fédéral de la statistique, $D u$ travail, mais pas de salaire, 64 p. Par «travail non rémunéré» on entend toutes les activités (dont les tâches domestiques et familiales constituent la majeure partie) qu'il serait possible de faire exécuter contre rémunération par des tiers (principe de la tierce personne). Le cadre décrit est confirmé aussi dans la nouvelle publication qui vient d'apparaître en janvier 2002. Voir Neue Zürcher Zeitung (NZZ), Hausarbeit geht auch Väter etwas an. Das Gleichstellungsbüro ruft zu «Fairplay at home» auf, 15. Januar 2002.

5 La charge ne diminue pas beaucoup pour les personnes élevant seules leurs enfants. 
selon cette division traditionnelle travaillent en fin de compte quasiment le même nombre d'heures (graphique 7).

Il en va autrement pour les femmes avec des enfants lorsqu'elles exercent une activité professionnelle. Il est démontré que la moyenne des heures consacrées aux activités domestiques ne diminue pas de manière conséquente avec l'emploi (graphique 8). C'est une des raisons pour lesquelles une bonne moitié des mères avec des enfants en bas âge n'exerce aucune activité lucrative, tandis qu'un quart travaille à moins de 50\% (graphique 9). Seulement $20 \%$ concilient les tâches domestiques avec un emploi à plein temps ou à plus de $50 \%$. Le problème de la réinsertion dans le marché du travail est souligné par le fait que même les mères avec des enfants de 15 à 24 ans cherchent pour la plupart à être employées à moins de $50 \%$ (graphique 9).

1) Activité principale par sexe en Suisse en 1997 (en \%)

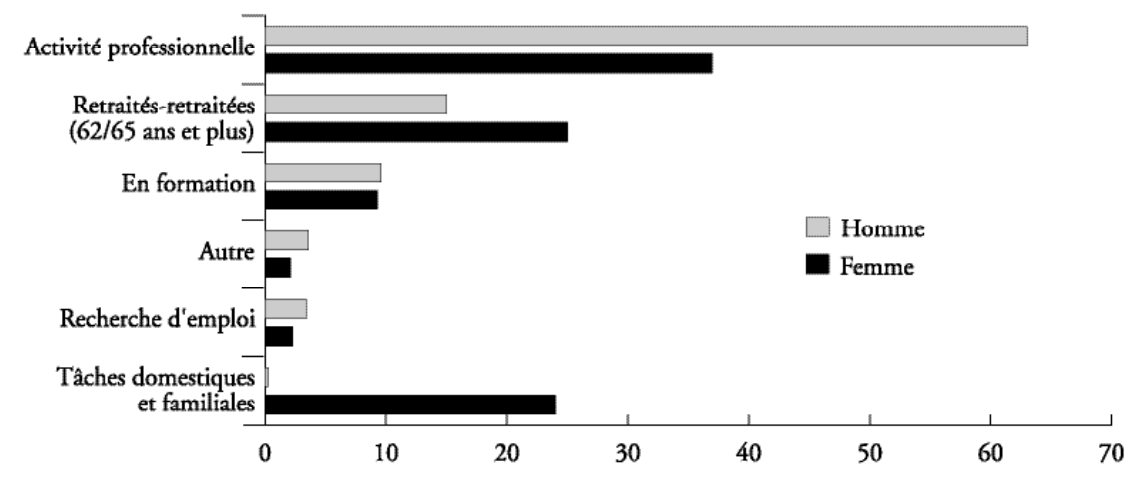

Source des graphiques 1 à 9: Office fédéral de la statistique, Du travail, mais pas de salaire. Le temps consacré aux tâches domestiques et familiales, aux activités honorifiques et bénévoles et aux activités d'entraide, Données sociales - Suisse, Neuchâtel, 1999, 64 p. Elaboration personnelle. 
2) Responsabilité principale des tâches domestiques (en \%)

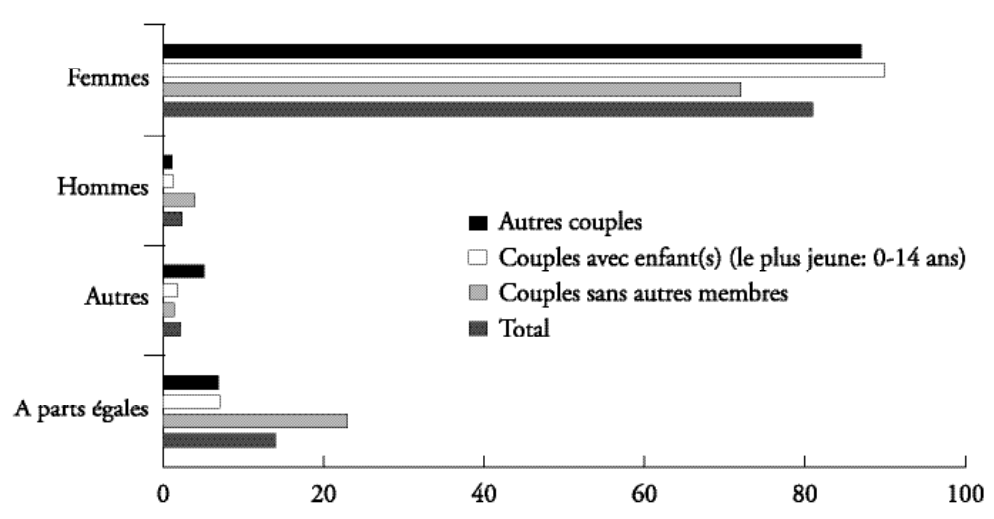

3) Pourcentage de temps par semaine consacré en moyenne aux tâches domestiques et familiales $(38,3 \mathrm{~h} / \mathrm{sem}$. au total)

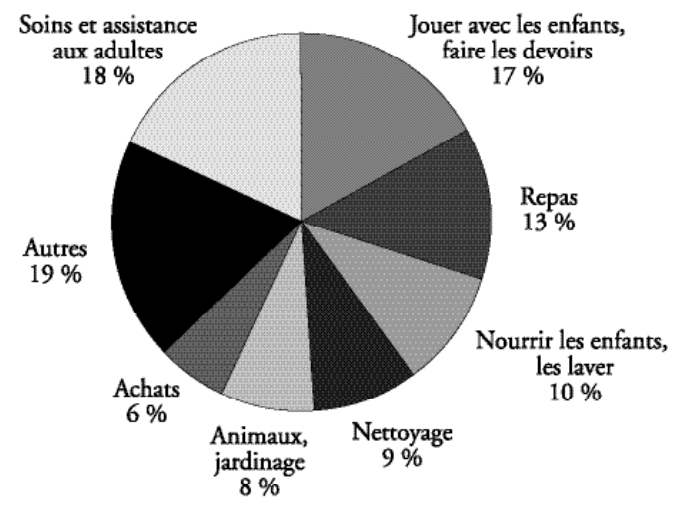


4) Nombre d'heures par semaine

consacrées en moyenne aux tâches domestiques et familiales

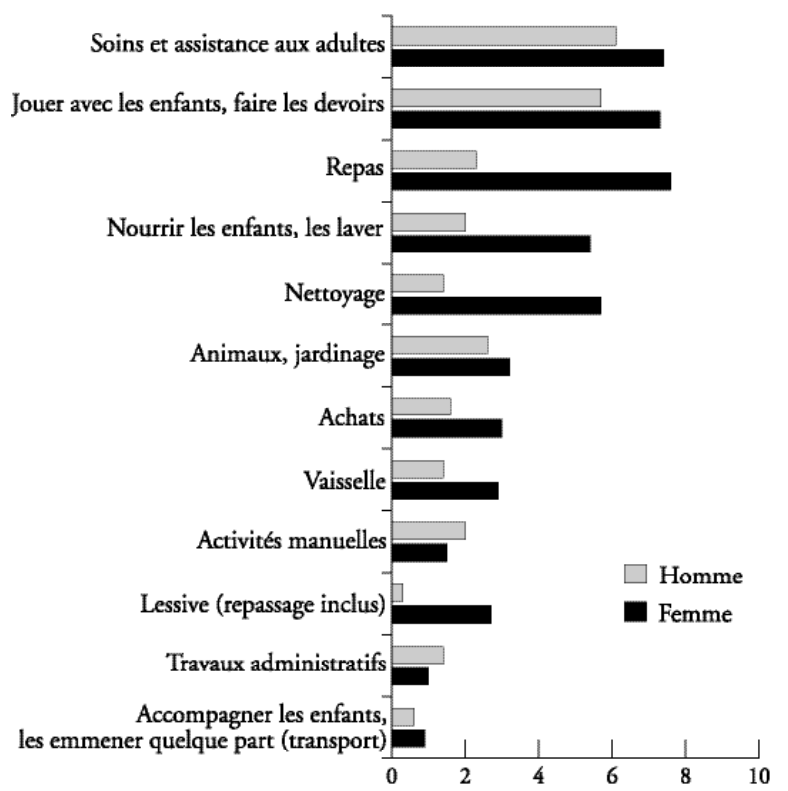

5) Nombre d'heures par semaine consacrées aux tâches domestiques et familiales, selon groupe d'âge

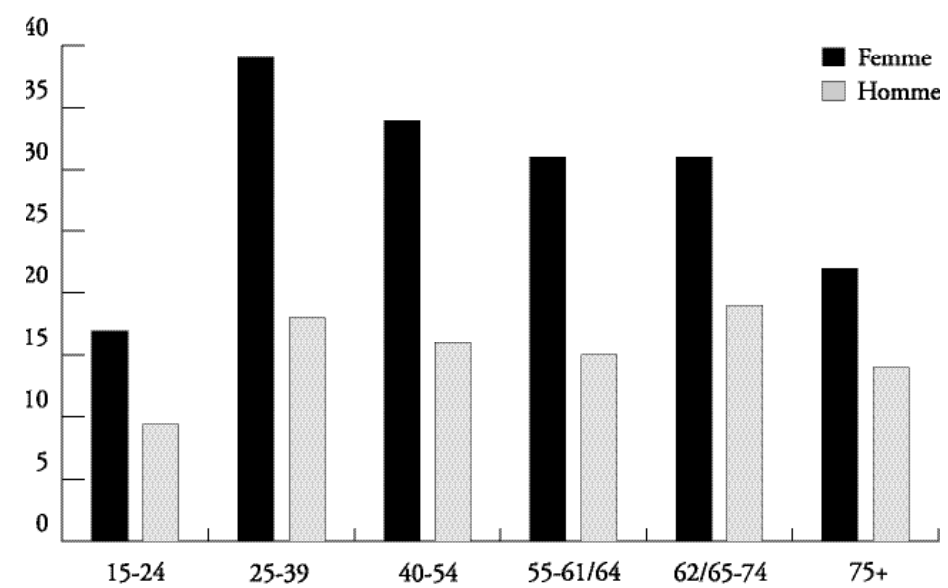


6) Nombre d'heures par semaine consacrées en moyenne aux tâches domestiques et familiales, selon situation familiale et sexe

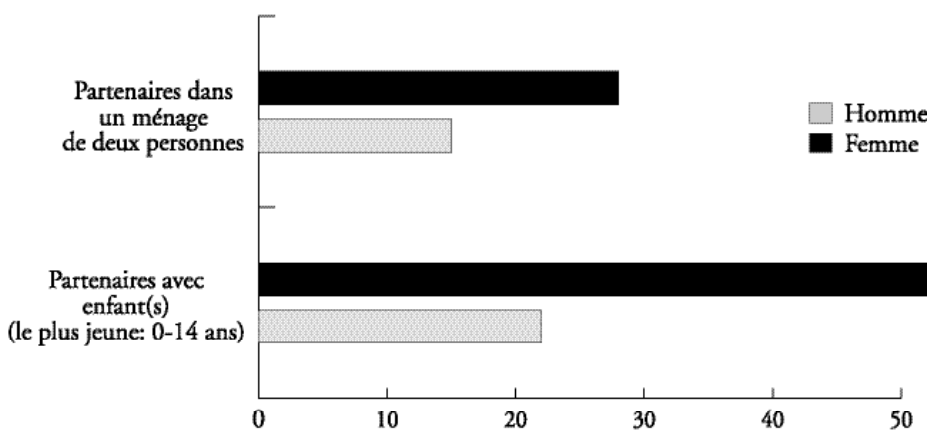

7) Nombre d'heures par semaine consacrées en moyenne à l'activité professionnelle et aux tâches domestiques et familiales selon activité pricipale

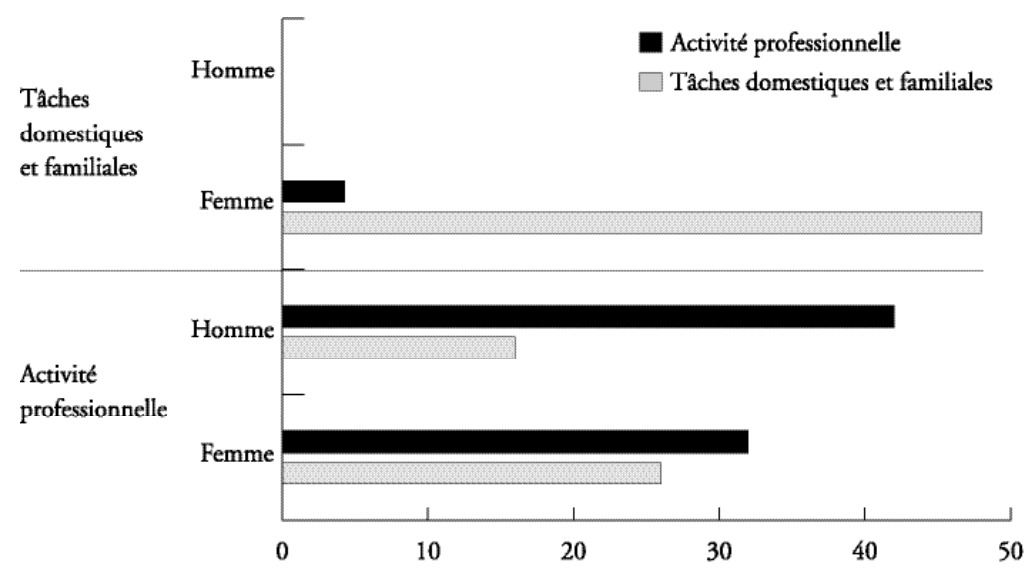


8) Nombre d'heures par semaine consacrées en moyenne par les mères de famille aux tâches domestiques et familiales selon taux d'occupation

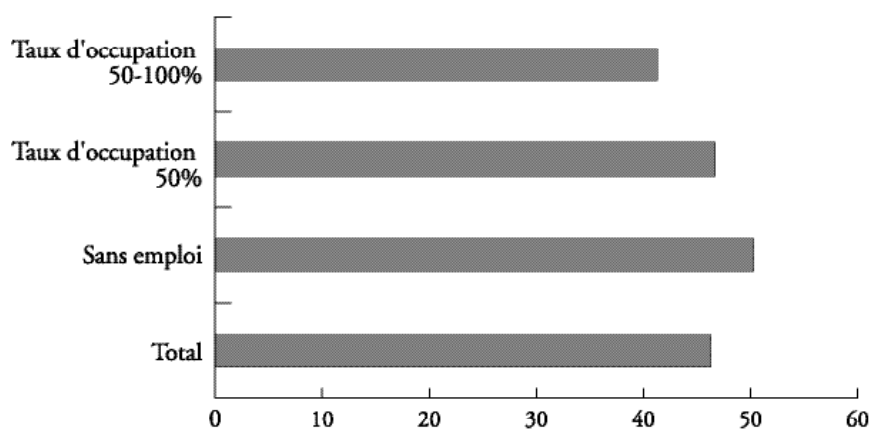

9) Taux d'occupation des mères de famille

selon l'âge du plus jeune des enfants (heures par semaine)

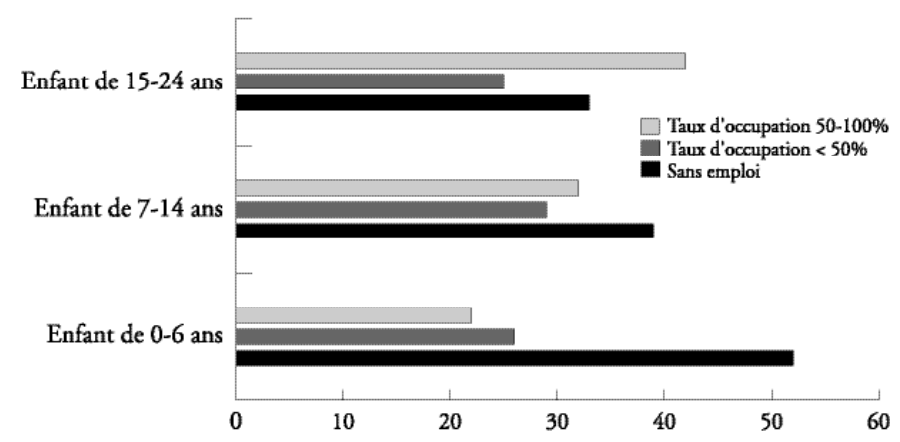




\section{ANALYSE DES CAUSES DE LA DIVISION SEXUELLE DU TRAVAIL RÉMUNÉRÉ ET DOMESTIQUE}

Historiquement, la position de la femme dans la société suisse est le résultat de la combinaison des variables suivantes ${ }^{6}$ : la représentation culturelle, le développement économique, la pression démographique, la législation et les mentalités. Ce paragraphe analyse la division sexuelle du travail en Suisse à partir d'une perspective de genre.

DIMENSION SYMBOLIQUE:

ORIGINES SOCIALES DE LA DIVISION SEXUELLE DU TRAVAIL

Comme Federici, $\mathrm{Mies}^{7}$ considère la division sexuelle du travail actuelle comme étant partie intégrante des relations de production caractérisées par la domination et l'exploitation ${ }^{8}$ : patriarcat au niveau familial, capitalisme au niveau de la société entière. Le mythe fondateur des deux formes est celui de l'homme-chasseur et guerrier: la viande qu'il procurait au groupe était censée servir de base à la reproduction de la communauté entière. Ce cadre serait à la base de la division sexuelle du travail. Les tâches attribuées aux femmes étaient définies comme naturelles. Ce lien avec la nature implique que le travail domestique et de reproduction n'apparaissait pas comme un travail qui produisait un «surplus» dans le système capitaliste. La femme est de ce fait définie comme non-travailleur.

Mies démontre, au contraire, que la femme est à l'origine de la première division sexuelle du travail basée sur une activité de récolte, ensuite de culture ${ }^{9}$, apte à assurer une subsistance régulière tout d'abord aux membres de l'unité sociale de base: mère et enfants.

6 Mottu-Weber Liliane, Head-Koenig Anne-Lise, Ungleichheiten zwischen Frauen und Männern., p. 39.

7 Mies Maria, The Social Origins of the Sexual Division of Labour, $49 \mathrm{p}$.

$8 \quad$ Ibid., p. 42. Exploitation: la séparation plus ou moins permanente et la hiérarchisation entre producteurs et consommateurs.

9 L'invention des instruments de culture détermine la révolution néolitique. Ibid., p. 15. 
Une activité qui se révèle beaucoup plus importante pour la reproduction sociale du groupe que l'activité de chasse de l'homme caractérisée par des résultats irréguliers. Le rapport entre femme et nature s'étend à la capacité de la reproduction sociale, donc au-delà de la reproduction physique: la femme est productive à titre absolu.

Cette structure sociale se serait transformée lorsque les nomades pasteurs ont envahi les communautés agricoles dans lesquelles la femme était la vraie cellule productrice. La nouvelle économie productive est basée sur la domestication et la fécondation coercitive des femelles étendues par la suite à la femme. L'élevage d'animaux induit la réduction du rôle de la femme à celle de procréatrice: il y a un changement dans la division sexuelle du travail qui établit la relation patriarcale. Dans les sociétés agricoles, dites sociétés d'économie domestique, l'appropriation des femmes par l'homme signifiait une source directe d'accumulation et de propriété privée ${ }^{10}$.

Ce mode d'appropriation est devenu le paradigme de toutes les relations d'exploitation entre les êtres humains, dont le capitalisme fait partie selon Mies. Sa logique principale est la transformation des producteurs autonomes en producteurs pour les autres. Ils sont ainsi assimilés à des ressources naturelles pour les autres. Lorsque l'accumulation de capital devient le moteur dominant de l'activité productive au détriment de la production de subsistance, le salaire tend à devenir la forme de contrôle dominante. Cependant, ce passage du binôme patron-servant vers une relation contractuelle entre capital et salaire n'aurait pas été possible sans l'expansion d'un système d'appropriation prédateur basé sur l'esclavage et la définition de la nature exploitable.

Par analogie, la femme bourgeoise est aussi soumise à cette naturalisation. Au niveau du couple, la violence directe, qui a permis d'établir une relation de genre asymétrique, est substituée par les institutions de la famille et l'Etat et par de puissants systèmes idéologiques, sur-

10 La première forme de propriété privée a été une femme kidnappée en tant que productrice. Ibid., p. 27. 
tout les religions patriarcales définissant la femme comme une partie de la nature qui doit être dominée et contrôlée par l'homme. A l'intérieur des limites définies par les lois du mariage et de la famille, l'homme dispose des moyens de coercition. Le foyer et la famille sont définis comme sphère naturelle domestiquée non productive et donc non rémunérée, distincte de la production publique et sociale.

Selon Mies, la projection du paradigme de l'évolution humaine basé sur l'homme-chasseur sert de légitimation universelle, atemporelle et naturelle de la domination actuelle de l'homme sur la femme. En considérant que la plupart des gens vivent dans une société basée sur le revenu salarial, le fait que le travail domestique ne soit pas payé affecte le statut social et le pouvoir des femmes.

\section{DIMENSION SOCIALE: INTERDÉPENDANCE}

\section{ENTRE TRAVAIL DOMESTIQUE ET TRAVAIL RÉMUNÉRÉ}

Dans la perspective de la $4^{\mathrm{e}}$ conférence mondiale des femmes au sein des Nations unies, la Commission fédérale a souligné qu'en Suisse la femme a accès à tous les domaines sociaux, mais ce fait n'induit pas pour autant une situation d'égalité des femmes par rapport aux hommes ${ }^{11}$. Le démantèlement des barrières formelles légales ne change pas de fait les hiérarchies de genre. Il y a passage de la discrimination directe à une discrimination indirecte.

Une manifestation de cette discrimination indirecte est vécue par la femme dans le monde du travail et de la famille, où un abîme existe entre les femmes qui entendent et peuvent suivre le modèle masculin de l'activité professionnelle continue, et celles dont la participation au marché du travail est limitée par les contraintes familiales.

Le mythe fondateur de l'homme-chasseur est à la base de la conception traditionnelle des rôles entre homme et femme qui, selon

11 Nadai Eva, Grenzverschiebungen., p. 7. L'ouvrage traite les différents aspects d'une tendance au passage des mécanismes de la reproduction des rapports de genre directs aux indirects dans différents domaines sociaux. 
Bauer $^{12}$, joue un rôle fondamental dans la division sexuelle dans le monde du travail et le monde familial en Suisse. La partie empirique de sa recherche confirme et ajoute quelques points de réflexion au cadre descriptif présenté jusqu'ici. Tandis que, lors de la fondation d'une famille, les femmes assument presque la totalité du travail familial en réduisant fortement leur propre travail lucratif, les hommes ne modifient pas leur comportement face au travail. Sur le marché du travail, les femmes gagnent environ $25 \%$ de moins que les hommes par heure de travail. Dans les professions typiquement féminines et à temps partiel, les différences salariales sont particulièrement marquées. Une année supplémentaire d'éducation a plus d'incidence sur le salaire de l'homme $(+4 \%)$ que sur celui de la femme.

La répartition inégale du travail est à la fois conséquence et cause de l'inégalité des salaires et de la segmentation du marché du travail ${ }^{13}$. Conséquence puisque la différence salariale fait que dans un couple, la femme semble être moins productive que l'homme. Il apparaît donc rationnel que l'homme consacre son temps entièrement à son activité professionnelle (par rapport au travail familial) et la femme d'abord au travail domestique. La discrimination salariale empêche la réduction du partage inégal des tâches familiales. Les conséquences alimentent les causes. Selon Bauer, la conception traditionnelle des rôles et la répartition effective qui en résulte est le facteur essentiel de la différence salariale. La conception traditionnelle des rôles constitue toujours une cause essentielle de la moindre activité de

12 Bauer Tobias, Une analyse économique des interdépendances entre travail domestique et tra vail rémunéré, 213 p. Le cœur de son analyse, basée sur les données de l'enquête suisse sur la population active de 1995 concernant 32'000 ménages, est les déséquilibres prononcés entre hommes et femmes dans les deux domaines mentionnés. En particulier, les quatre secteurs suivants sont analysés: 1) la situation familiale (partenaire, enfants); 2) l'emploi du temps (activité lucrative, travail non rémunéré); 3) la constitution du capital humain (formation, expérience professionnelle) ; 4) les chances sur le marché du travail (salaire potentiel, position hiérarchique).

13 Bauer Tobias, Ibid., p. 7. Parmi les théories utilisées pour expliquer cette inégalité liée au sexe, Bauer utilise la théorie de la segmentation du marché du travail d'inspiration sociologique: le marché du travail se laisse diviser par le sexe en segments qui sont caractérisés par différents mécanismes de rétribution et promotion. 
formation des jeunes femmes et de leur concentration sur les professions féminines typiques, où les chances de promotion sont faibles. Les femmes choisissent des travaux typiquement féminins, et ont des conditions de salaire et de promotion moins favorables que les hommes au même poste. La discrimination salariale constitue une barrière considérable pour l'éradication de l'inégalité au sein d'une famille. Les moindres activités des femmes en matière de formation et de vie professionnelle deviennent donc des choix rationnels. Le travail à temps partiel représente souvent la seule possibilité pour les femmes de combiner travail et famille.

La grande stabilité du partage des rôles est due principalement à ces «interdépendances circulaires» qui se renforcent mutuellement au cours du temps: l'inégalité dans un domaine amène à maintenir l'inégalité dans un autre domaine et perçue comme rationnelle sur le plan économique.

\section{DIMENSION INDIVIDUELLE:}

PERCEPTION DE L'INÉGALITÉ ET DE LA JUSTICE DANS LE COUPLE

Selon Mies, la femme a été suffisamment disciplinée pour travailler comme femme de ménage par le processus de «naturalisation». Elle a appris à contourner l'injustice réelle subie, exercée par les différentes institutions pendant des siècles, et à l'intérioriser en la définissant comme «amour» selon un processus que Mies appelle «la nécessaire mystification de l'autorépression ${ }^{14}$.

Cette affirmation introduit la composante subjective dans le rapport de genre concernant la répartition sexuelle entre le travail rémunéré et le travail domestique. Dans sa recherche, Roux ${ }^{15}$ s'applique à répondre à la question de savoir comment une inégalité objective

14 Mies Maria, op. cit., 40 p.

15 Roux Patricia, Gerechtigkeit und Ungleichheit in Paarbeziehungen, pp. 245-270. L'auteur présente les résultats d'une enquête menée sur 200 hommes et 200 femmes mariés pour connaître leur perception de leur propre situation dans la perspective d'inégalité de genre dans la famille. 
dans les rapports de genre n'est pas ressentie comme injuste par les femmes. Plusieurs facteurs déterminent la perception et l'expérience individuelles de la discrimination.

Concrètement, la participation des hommes aux tâches ménagères n'est pas voulue par les femmes. Pour certaines, ces activités sont valorisantes et confèrent une reconnaissance personnelle. Le partage (traditionnel) des rôles attribuant à la femme cette responsabilité n'est pas perçu comme inégal et injuste et contribue donc à un renforcement de ce type de relation.

Les concepts d'égalité et de justice sont soumis à des processus d'évaluation et de construction individuels et collectifs (normatifs) qui s'influencent mutuellement ${ }^{16}$. Le processus de l'acceptation d'être la victime directe d'une situation d'injustice sociale, le passage à une action en faveur de la revendication de ses propres droits demande du temps. Cela affecte les relations personnelles que l'individu veut sauvegarder malgré une situation d'inégalité.

Le sentiment d'injustice naît généralement de la comparaison. L'inégalité dans les rapports de genre au niveau collectif est plus facilement décelée que dans les relations personnelles. Concrètement, la situation d'inégalité entre homme et femme dans les foyers en général est surévaluée par rapport à son propre foyer. Une première cause de cette minimisation est que les femmes ont des attentes limitées concernant le futur, elles peuvent ainsi juger positivement leur relation et avoir la sensation d'avoir la situation sous contrôle. Un positionnement critique par rapport à l'asymétrie dans les rapports de genre en général n'a aucune incidence sur la construction de la justice dans le quotidien. La perception de la discrimination est socialement ancrée. La femme qui a un travail à l'extérieur évalue plus fortement la double charge comme une forme de discrimination. Le travail rémunéré de la femme ajoute au

16 Bien que pas dans la même mesure, les normes dominantes sont bien plus fortes et agissent sur l'individu. 
partage inégal des rôles, et renforce sa conscience de la discrimination qu'elle subit. Concrètement, plus la femme est consciente de l'inégalité du partage des tâches dans le couple, plus elle critique la non-participation du partenaire.

La perception influe le jugement de la femme quant à la situation d'injustice. Le partage des rôles et l'activité rémunérée de la femme sont deux facteurs qui influencent donc les représentations sociales.

Schéma 1: Emergence du sentiment d'injustice par rapport à la répartition sexuelle du travail dans le couple

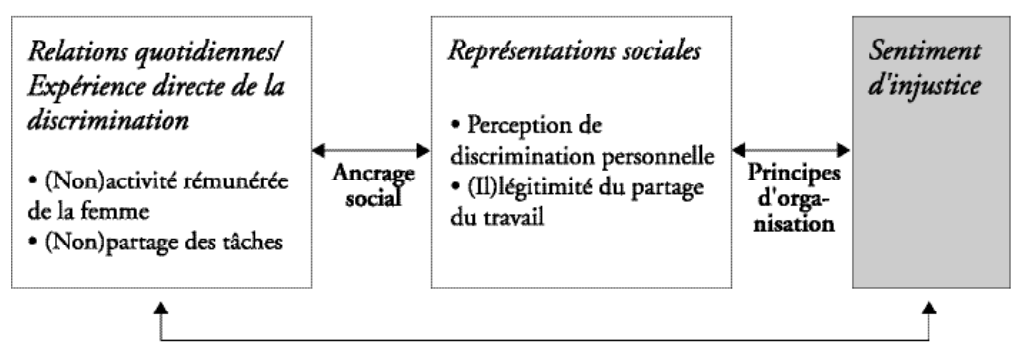

La répartition choisie entre travail rémunéré et travail domestique a une incidence sur le jugement du partage des tâches et influence en même temps la perception de la discrimination. L'organisation traditionnelle des ménages correspond au modèle dominant où chaque partenaire a son propre domaine d'activité. La complémentarité des contributions est plus importante que l'égalité des rôles et donc le concept de justice dépend de ce que chacun fournit dans son propre domaine. L'apport de l'homme aux tâches ménagères et familiales est jugé suffisant eu égard à son engagement dans l'activité rémunérée. Le principe de justice plus souvent utilisé pour régler les relations du couple est celui de la "conformité»17. Le principe de conformité peut garantir la paix dans le couple puisqu'il permet, d'une part, de gérer l'organisation nécessaire du quotidien, et, de

17 Roux Patricia, Ibid., p. 263. 
l'autre, de créer pour chacun un équilibre entre attentes normatives et satisfactions vécues.

Par ce processus, le couple traditionnel est immunisé contre le jugement d'injustice et d'inégalité. Ce manque de recul par rapport à la répartition du travail dans le couple s'explique partiellement par l'incapacité à s'imaginer un changement de ces habitudes. L'inégalité est ainsi voilée et la femme se plie à la situation.

\section{PARTAGE DU TRAVAIL DOMESTIQUE ENTRE FEMMES DANS UN CONTEXTE DE MONDIALISATION ÉCONOMIQUE: ANALYSE SOCIO-ÉCONOMIQUE ET ANTHROPOLOGIQUE}

Dans le chapitre précédent, on a pu constater les barrières symboliques, sociales et individuelles qui empêchent une répartition sexuelle équitable entre le travail rémunéré et le travail domestique. La vie professionnelle des femmes présente trois cas de figure. Tout d'abord, celle qui quitte le marché du travail au moment de créer une famille et qui reprend une activité professionnelle plus tard. Deuxièmement, la femme qui choisit d'interrompre son activité professionnelle à plusieurs reprises, pour la reprendre autant de fois. Troisièmement, celle qui cherche une tierce personne pour accomplir les tâches domestiques et familiales. Bauer nous apprend qu'aujourd'hui le scénario le plus commun est celui où les femmes engagent des tiers pour les travaux domestiques et familiaux. Cela leur permet de poursuivre une activité professionnelle ${ }^{18}$. Selon Költzsch, $48 \%$ des femmes reçoivent de l'aide d'une autre personne pour le travail domestique ${ }^{19}$. La Neue Zürcher Zeitung nous apprend qu'en Suisse, il existe une forte demande d'emploi dans le domaine de

18 Bauer Tobias, Ibid., p. 155.

19 Költzsch Ruch Kerstin, Familienkompetenzen - Rustzeug für den Arbeitsmark., p. 31. Dans le cadre de la recherche, 102 personnes ont été interrogées (86 femmes [84\%], 16 hommes $[16 \%])$. Ce chiffre doit être relativisé du fait qu'il ne met pas en lumière la différence entre partenaire et une autre personne (payée ou non). 
l'économie domestique ${ }^{20}$. En Suisse, il y aurait entre 50'000 et 150 '000 personnes clandestines, dont une grande partie active dans le domaine mentionné. Quant à l'économie informelle, une analyse rapide des annonces d'offres et demandes d'emploi pour petits travaux dans l'hebdomadaire genevois $G H I^{21}$, donne les résultats suivants: la plupart des annonces concernent la main-d'œuvre féminine $(72 \%)$, dont les offres $(50 \%)$ et les demandes $(57 \%)$ concernent les travaux domestiques.

Pour avoir une idée de l'ampleur du phénomène dans l'économie formelle ${ }^{22}$, on peut comparer les 27'000 personnes employées dans les services de l'économie domestique en Suisse en 1990 avec les 32'000 ménages révélés par l'enquête fédérale sur l'économie domestique en 1995. En suivant le raisonnement de Fox ${ }^{23}$, la valeur attribuée au travail domestique d'une femme correspondrait à l'équivalent de son éventuel travail rémunéré. Cette valeur met en évidence la quantité du travail domestique fourni par rapport à la quantité d'heures de travail permettant d'accéder aux mêmes services payés. L'engagement d'une aide domestique n'est rationnel que quand le travail domestique est moins payé que ces mêmes services sur le marché du travail (graphique 10).

En Suisse, les services de l'économie domestique constituent un secteur économique majoritairement féminin (89\%) (graphique $11^{24}$ ).

20 Neue Zürcher Zeitung (NZZ) Online, Der Preis für die Arbeit ist «ein Leben im Gefängnis», 16. Januar 2002.

21 GHI, Marché de l'emploi, 27 sept., 25 oct. et 1 nov. 2001, Genève.

22 Du point de vue strictement comptable, elle représente la quantification de la création de la valeur ajoutée qui rentre systématiquement dans le calcul du produit social national.

23 Fox Bonnie (Ed.), Hidden in the Household, p. 20.

24 Les données statistiques se réfèrent au groupe «392 Professions de l'économie domestique» dans Office fédéral de la statistique, Recensement fédéral de la population 1990. Emploi et vie active. Tableaux thématiques, Berne, 1993, 362 p. Ce groupe contient deux ensembles différents de professions: a) «392.01 Intendants de maison»: par exemple conseiller en économie ménagère, gouvernant diplômé, gouvernant de maison, intendant de maison ESEF, maître d' apprentissage ménager, etc. ; b) «392.02 Employés de maison »: par exemple aide de foyer, aide de maison, aide de ménage, collaborateur d'entretien de maison, employé de maison, employé de ménage, fille au-pair, etc. Le 
On observe également que les étrangères y sont plus présentes (35\%) que sur le marché du travail en général $(7 \%)$. Le taux d'occupation des étrangères est plus élevé que celui des Suissesses en termes de durée de travail (graphique 12) ${ }^{25}$. De plus, ce secteur occupe la catégorie de main-d'œuvre considérée comme non qualifiée $(60 \%$ du total), chiffre supérieur à celui du marché suisse en général $(22 \%)$ (graphique 13). Le bas niveau de qualification est reflété par le niveau des salaires mensuels, 3'127 fr. pour les femmes (graphique 10). Dans le secteur informel, l'estimation est de 3'010 fr. ${ }^{26}$. Le secteur des services domestiques se caractérise donc par une forte concentration de main-d'œuvre non-qualifiée, étrangère et peu payée.

C'est l'expérience de beaucoup d'immigrées originaires des pays en voie de développement (PED) qui subviennent aux besoins de leurs familles restées au pays. Portier ${ }^{27}$ met en évidence le prix très lourd qu'elles payent. Tout d'abord, la "politique des trois cercles» n'autorise pas les ressortissant-e-s des pays du troisième cercle (PED) à travailler en Suisse. Les immigrées originaires de ces pays ne peuvent pas pratiquer leur profession, sauf s'il s'agit d'un parcours exceptionnel. L'immigrée subit la perte de son statut juridique et social antérieur. Elle exerce un travail peu valorisant par rapport à son niveau d'instruction. Elle est souvent exploitée, car elle n'est pas protégée par des lois et risque de se voir expulser vers son pays. Elle vit dans des conditions précaires en marge de la nouvelle société et loin de sa famille.

deuxième groupe correspond parfaitement aux professions concernant les tâches domestiques et familiales considérées dans le travail. Pour le groupe des intendants de maison la représentativité est plus faible.

25 J'ai choisi une série de trois groupes horaires consécutifs qui constitue le plus grand pourcentage selon l'origine de la personne active. Les résultats du graphique doivent être relativisés par le taux des «sans indications» assez haut pour le cas des travailleuses suissesses.

26 Je calcule la moyenne entre salaire horaire pour une femme de ménage (20 fr.) et une garde d'enfants (15 fr.). Le premier chiffre est confirmé par (NZZ) Online, Der Preis für die Arbeit ist «ein Leben im Gefängnis», 16. Januar 2002. Le deuxième représente un chiffre vraisemblable pour le marché informel à Genève. L'entité du salaire est confirmée aussi dans Mudry Jean-Paul, Feuz Alec, Clandestines, 2000.

27 Portier Servan Alegre Véronique, La femme émigrée péruvienne à Genève, pp. 86-93. Le cadre décrit par Portier est confirmé par l'enquête de Mudry Jean-Paul, Feuz Alec, Clandestines..., 2000. 
10) Salaire mensuel brut au niveau 4 des qualifications requises en Suisse dans les services de l'économie domestique formelle et informelle

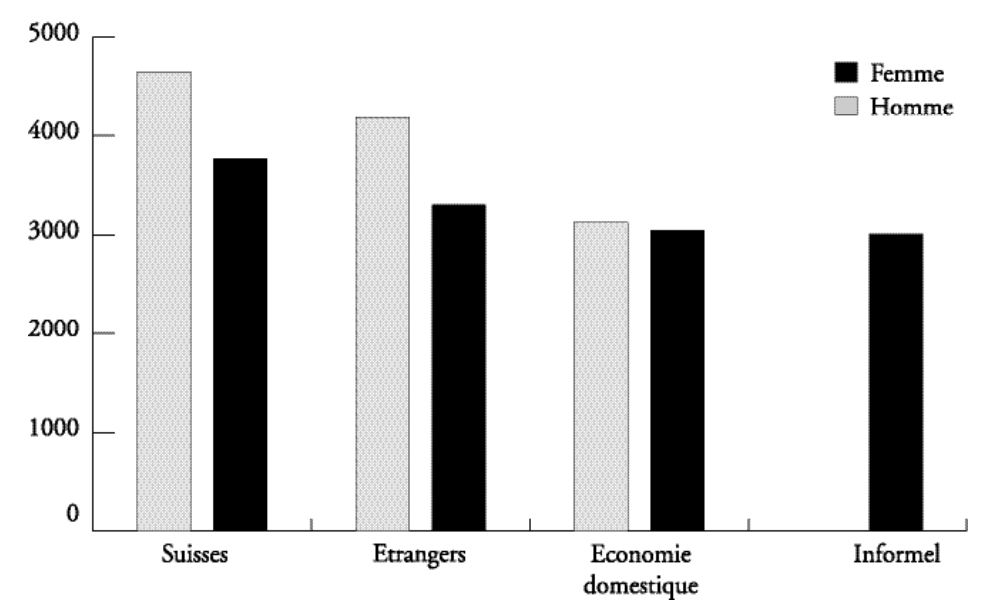

11) Personnes actives en Suisse et dans les services de l'économie domestique en 1990
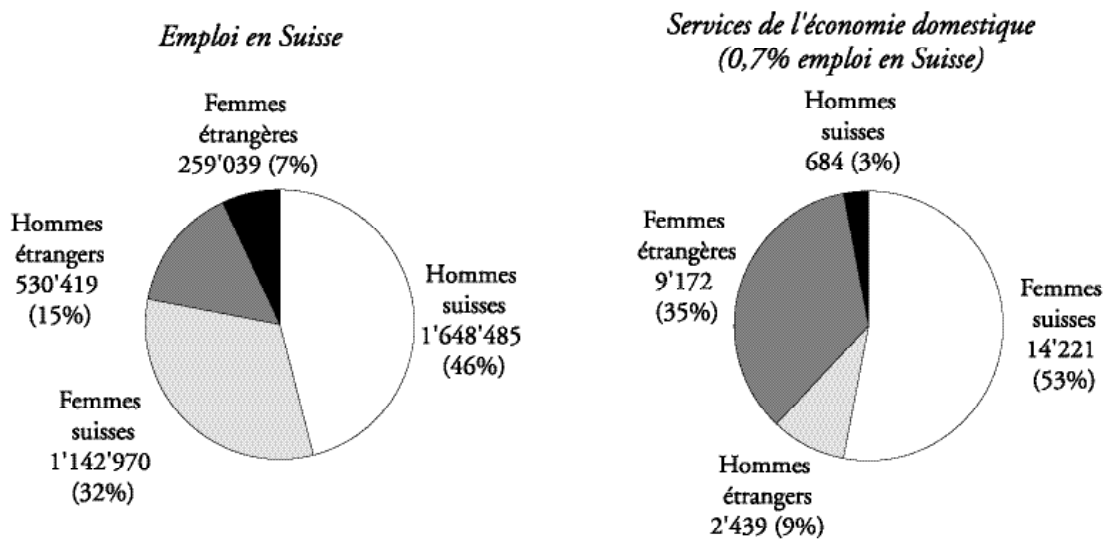

Sources des graphiques 10 à 13: Office fédéral de la statistique, Enquête suisse sur la structure des salaires 1998. Résultats commentés et tableaux, Neuchâtel, 2000, 52 p. Elaboration personnelle; Office fédéral de la statistique, Recensement fédéral de la population 1990. Emploi et vie active. Tableaux thématiques, Berne, 1993, 362 p. Elaboration personnelle. 
12) Femmes actives occupées dans les services de l'économie domestique selon leur origine et la durée du travail (heures/semaine) en 1990

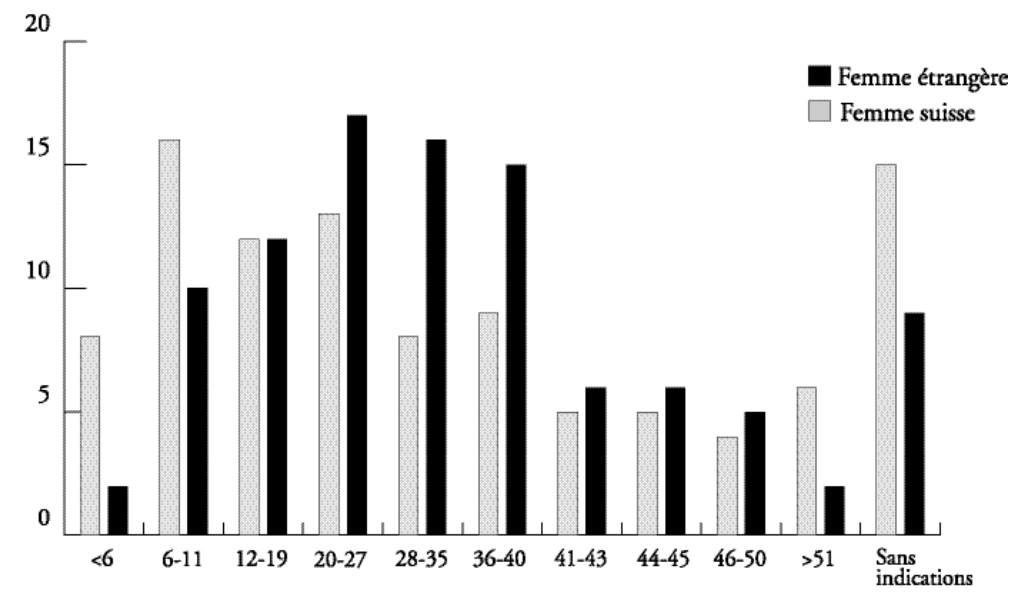

13) Personnes actives occupées en Suisse et dans les services de l'économie domestique selon les catégories socio-professionnelles

Emploi en Suisse

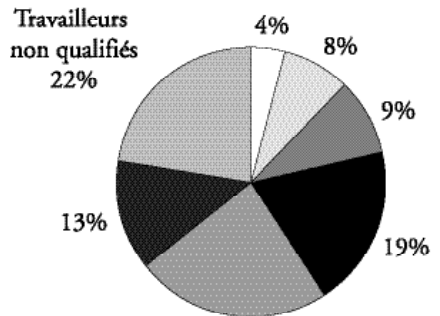

Non-manuels: employés qualifiés $23 \%$
Services de l'économie domestique

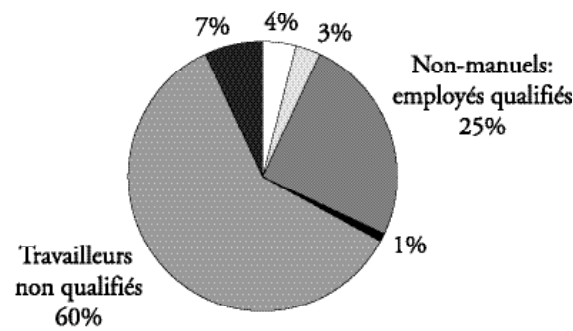


D'une façon générale, selon Portier, la condition de la femme immigrée à Genève est un décalage entre le projet qui l'a amenée à émigrer et la possibilité de le réaliser. Il y a des exemples d'immigrées qui se donnent les moyens de progresser. Elles ont pu le faire en passant par l'acceptation d'une étape de régression: «déqualification» professionnelle, exploitation, isolement, perte du statut social et juridique. C'est le cas de $\mathrm{Nancy}^{28}$, Péruvienne arrivée clandestinement à Genève à l'âge de 31 ans. Professeure, diplômée universitaire au Pérou, elle trouve un emploi de femme de ménage par l'intermédiaire d'une annonce en espagnol. Elle travaille du lundi au samedi de 7 à 21 heures; elle s'occupe des enfants, du ménage, du repassage et de la cuisine pour un salaire de 900 fr. par mois. Cela dure quatorze mois. Puisqu'elle ne parle pas français et qu'elle ne peut sortir que le dimanche, les possibilités de changement sont limitées.

Cette vie de clandestin-e est faite de grandes souffrances. L'immigrée ne peut jouir des mêmes droits que les résident-e-s, ne peut vivre librement, sans la peur d'être dénoncé-e, souffre de solitude, ne peut pas trouver un travail à la hauteur de ses qualifications.

Grâce à la médiation d'une connaissance, Nancy trouve une autre famille, accueillante et respectueuse. Elle passe donc à ce que Portier appelle la «deuxième étape évolutive ${ }^{29}$ de l'immigré-e qui consiste en l'apprentissage de la langue, des études universitaires en lien avec sa profession antérieure, un nouveau statut social et juridique et un travail déclaré.

Laura 32 ans, originaire de l'Equateur et mère d'un enfant de 4 ans, ne rencontre aucun problème à trouver un travail en tant que fille au pair auprès d'une famille zurichoise, où elle accomplit des travaux domestiques, y compris la garde des enfants pour un salaire mensuel de 600 fr. En plus, elle travaille au noir comme femme de

28 Portier Servan Alegre Véronique, Ibid., pp. 52-56.

29 Portier Servan Alegre Véronique, Ibid., p. 87. 
ménage pour 22 fr. de l'heure. Elle peut ainsi épargner 1500 fr. par mois, dont la moitié est envoyée en Equateur. Laura compte continuer cette vie pendant deux ans.

\section{CONCLUSION: MONDIALISATION ÉCONOMIQUE, RELATIONS ENTRE FEMMES ET SOLUTIONS}

Le cas de la Suisse présenté ici semble confirmer le cadre analytique proposé par Federici. La répartition du travail rémunéré et du travail domestique se fait selon le modèle traditionnel: l'homme pratique l'activité rémunérée, la gestion du foyer est le domaine presque exclusif de la femme, même si elle exerce une activité rémunérée à l'extérieur.

J'ai essayé de saisir et de déconstruire les barrières symboliques, sociales et individuelles qui empêchent une répartition sexuelle équitable du travail.

La conception traditionnelle des rôles de l'homme et de la femme, basée sur la mystification de l'homme-chasseur assurant la survie du groupe, joue un rôle fondamental dans la position sociale actuelle de la femme suisse. Le modèle traditionnel est soutenu par le mécanisme de la «conformité» qui structure l'organisation sociale au sein du foyer. Ce mécanisme permet la perception d'une justice dans le couple, mais empêche une vraie justice sociale en ce qui concerne la répartition sexuelle du travail rémunéré et du travail domestique.

L'ensemble de ces barrières oblige les femmes, qui doivent ou qui entendent exercer une activité professionnelle, et les partenaires qui les soutiennent, à trouver des solutions individuelles. Une des solutions individuelles est l'engagement d'une tierce personne payée pour accomplir les tâches ménagères et familiales. Le marché du travail des services domestiques se caractérise par une forte concentration de main-d'œuvre non qualifiée et par conséquent peu rémunérée. Par rapport à d'autres secteurs du marché du travail en Suisse, il 
y a une forte concentration d'étrangères. Leurs conditions de travail sont précaires, compte tenu que ce sont surtout des immigrées clandestines qui travaillent dans ce secteur informel.

$\mathrm{Si}$, au niveau interpersonnel, la relation «madame-servante», c'est-àdire entre femme suisse et domestique étrangère, peut être vécue comme agréable (aide, échange), au niveau collectif, on peut parler d'un phénomène d'exploitation. Une solution «coloniale» qui empêche une vraie remise en question du modèle dominant de la division sexuelle du travail au sein de la famille et de la société dans un sens plus large.

Les mesures proposées par les différents auteurs consultés pour équilibrer les rapports de genre dans la répartition des tâches familiales et du travail rémunéré se situent à des niveaux institutionnel, culturel et politique. Bauer ${ }^{30}$ envisage une solution institutionnelle pour rompre le processus d'inégalité circulaire décrit ci-dessus. Il s'agit de mesures visant tout d'abord à garantir l'égalité des salaires sur le marché du travail. Selon Fox ${ }^{31}$, l'attribution d'une valeur au travail domestique pourrait stimuler le mécanisme de redistribution du travail de la femme entre foyer et travail rémunéré. Selon Roux ${ }^{32}$, l'introduction d'un modèle d'égalité basé sur une solidarité authentique implique des interventions sociales et politiques. Un changement de mentalité qui permet une ouverture envers d'autres modèles d'organisation sociale nécessite une nouvelle définition des rapports sociaux et surtout une stratégie appropriée pour la diffusion de ces idées: école et éducation, médias, mouvements sociaux, etc. Selon Roux, un changement structurel des conditions actuelles concernerait en particulier l'augmentation du nombre de garderies d'enfants, le démantèlement des marchés du travail segmentés et la reconnaissance économique du travail social non rémunéré. Le manque de reconnaissance économique de ce dernier fait également

30 Bauer Tobias, op. cit., p. 155.

31 Fox Bonnie (Ed.), op. cit., p. 20.

32 Roux Patricia, op. cit., p. 263. 
que les femmes au foyer sont désavantagées par le système des assurances sociales.

De leur côté, les hommes ont encore besoin d'une prise de conscience, ils manquent de la volonté et de la possibilité de structurer leur vie professionnelle $d^{\prime}$ 'une manière plus flexible. La discrimination salariale au détriment des femmes n'encourage pas un rééquilibrage de la répartition sexuelle du travail au sein du couple.

Sans les appuis institutionnel et culturel appropriés, la responsabilité domestique incombera à la femme et une activité professionnelle induira une surcharge. Une réponse à cette situation est l'engagement de tierces personnes, ce qui s'inscrit dans une tendance globale d'exploitation des personnes les plus défavorisées, en l'occurrence les immigrées en situation de clandestinité. 


\section{Bibliographie}

BAUER Tobias, Une analyse économique des interdépendances entre travail domestique et travail rémunéré pour la population féminine et masculine en Suisse, thèse de la faculté des sciences économiques et sociales de l'Université de Genève, no 502, Genève, 2000, $213 \mathrm{p}$.

FEDERICI Silvia, Reproduction et lutte féministe dans la nouvelle division internationale du travail. Dans DALLA COSTA M., DALLA COSTA G., Women Development and Labor of Reproduction, Struggles et Movements, Africa, World Press, Asmara, Eritrea, 1999, 15 p. FENSTERMARKER BERK Sarah, The Gender factory. The Apportionment of Work in American Households, Plenum Press, New York, 1985, 251 p.

KÕLTZSCH RUCH Kerstin, Familienkompetenzen - Rustzeug für den Arbeitsmarkt. Eine arbeitspsychologische Untersuchung zum Quantifizierungspotential der Familien- und Hausarbeit für die Berufswelt, Projekt Sonnhalbe Worb, Worb, 1997, 211 p.

MIES Maria, The Social Origins of the Sexual Division of Labour, Institute of Social Studies, The Hague - The Netherlands, no. 85, January 1981, 49 p.

MIES Maria, Patriarchat und Kapital: Frauen in der internationalen Arbeitsteilung, Zürich, 1992, 319 p.

MOTTU-WEBER Liliane, HEAD-KOENIG Anne-Lise, Ungleichheiten zwischen Frauen und Männern in der Schweiz aus historischer Sicht (vom Ende des Mittelalters bis zum 19. Jahrhundert), pp. 23-45. Dans NADAI Eva, Grenzverschiebungen. Zum Wandel des Geschlechterverhältnisses in der Schweiz, Verlag Rüegger, Chur/Zürich, 1998, 280 p.

NADAI Eva, Grenzverschiebungen. Zum Wandel des Geschlechterverhältnisses in der Schweiz, Verlag Rüegger, Chur/Zürich, 1998, 280 p.

NEUE ZÜRCHER ZEITUNG (NZZ), Hausarbeit geht auch Väter etwas an. Das Gleichstellungsbüro ruft zu «Fairplay at home» auf, 15. Januar 2002.

NEUE ZÜRCHER ZEITUNG (NZZ) Online, Der Preis für die Arbeit ist «ein Leben im Gefängnis», 16. Januar 2002.

OFFICE FÉDÉRAL DE LA STATISTIQUE, Recensement fédéral de la population 1990. Emploi et vie active. Tableaux thématiques, Berne, 1993, 362 p.

OFFICE FÉDÉRAL DE LA STATISTIQUE, Du travail, mais pas de salaire. Le temps consacré aux tâches domestiques et familiales, aux activités honorifiques et bénévoles et aux activités d'entraide, Données sociales - Suisse, Neuchâtel, 1999, 64 p.

OFFICE FÉDÉRAL DE LA STATISTIQUE, Enquête suisse sur la structure des salaires 1998. Résultats commentés et tableaux, Neuchâtel, 2000, 52 p.

PORTIER SERVAN ALEGRE Véronique, La femme émigrée péruvienne à Genève. Le tra vail, la famille, l'environnement, l'identité, travail de recherche à l'Institut d'études sociales, Genève, 1996, 98 p.

ROUX Patricia, Gerechtigkeit und Ungleichheit in Paarbeziehungen, pp. 245-270. Dans NADAI Eva, Grenzverschiebungen. Zum Wandel des Geschlechterverhältnisses in der Schweiz, Verlag Rüegger, Chur/Zürich, 1998, 280 p. 


\section{TABLE RONDE}

\section{«ECONOMIE MONDIALISÉE ET IDENTITÉS DE GENRE»}

\section{Retranscription et résumé par Fenneke Reysoo}

\section{Objectifs de la table ronde}

Nous attendons des participant-e-s au débat de la table ronde une courte présentation de leur organisation et leurs points de vue et com mentaires sur cinq énoncés qui seront introduits par Frans Schuurman.

Au public:

Avant de débattre sur chaque énoncé, nous vous demanderons de vous exprimer par un vote. Après la présentation des divers points de vue des participant-e-s de la table ronde, vous voterez une deuxième fois. Cette interaction nous permettra de voir si les discussions et les différentes visions ont une influence sur vos opinions de départ. 


\section{INTRODUCTION}

MONDIALISATION: THÈMES ET PIÈGES

\section{Frans Schuurman}

Frans Schuurman est enseignant-chercheur au Centre for International Development Issues (CIDIN) de l'Université de Nimègue, aux Pays-Bas. ${ }^{1}$

Dans le débat sur la mondialisation, on peut distinguer différentes prises de position. Il est important de s'y arrêter un instant afin de prendre conscience de quoi on parle en se référant à la mondialisation. Pour simplifier la discussion, je présente cinq types de «mondialistes»:

- Les vrais mondialistes. Ils considèrent la mondialisation comme une époque tout à fait nouvelle qu'il ne faut pas confondre avec la modernité.

- Les cybermondialistes. Ils disent la même chose, mais spécifient que c'est la cybernétique qui en fait une époque à part.

- Les non-mondialistes. Ils défendent que la mondialisation n'est rien de nouveau, que cela a toujours existé. Ils se réfèrent avant tout à l'époque expansionniste entre 1870-1914. Ils voient le processus de mondialisation à partir des années 1985 comme une nouvelle vague de l'expansionnisme capitaliste et impérialiste.

- Les marxistes. Ils considèrent la mondialisation comme l'expansion du capitalisme autour du globe.

- Les postmondialistes. Ils disent que s'il y a eu une période de mondialisation, il n'en est plus rien maintenant. On assiste à un tribalisme néolocal et l'universalisme est sur son retour. Les Etatsnations s'effritent et il y a émergence de nouvelles entités, non modernes et basées sur des identités néotribales.

Frans Schuurman (ed.), 2000, «Globalization and Development Studies: Challenges for the 21st century». Amsterdam: Thela Thesis. 
On pourra également penser à établir une taxonomie en termes de bien et de mal. Les positivistes pensent que la mondialisation est une chose objective régie par un système extérieur. Ce point de vue est important, car cela implique que l'on ne peut plus l'arrêter, c'est quelque chose - technologie, capitalisme, impérialisme - qui est là et que l'on ne peut influencer. Ils pensent qu'il n'y a pas d'alternative, qu'il ne sert à rien de le combattre, qu'il faut suivre le courant.

Les antimondialistes disent que la mondialisation est un mal et qu'il est mené par des acteurs. Ce qui signifie qu'il y a des agents au sein du système mondial qui sont responsables des processus de mondialisation. C'est une prise de position diamétralement opposée au point de vue systémique. Quand on dit qu'il y a des responsables, il faut les rendre redevables de ce qui est bien et mal - en notre cas ce qui est mal - dans le processus de mondialisation. Il y a également les réformistes. Ils veulent inventer une sorte de keynésianisme mondial afin de combattre le mal et maintenir les bons éléments de la mondialisation.

Le débat sur la mondialisation est basé sur un grand nombre d'indicateurs, causes et conséquences. Ils sont souvent interchangeables dans la façon de présenter les réalités. Ce que les uns appellent des indicateurs de la mondialisation sont tenus pour des causes ou des conséquences par d'autres. Il faut donc avoir à l'esprit la variation de types de mondialisation et se demander à chaque fois s'il s'agit d'indicateurs, de causes ou de conséquences.

A propos de la discussion sur la mondialisation, dans la littérature il semble y avoir un consensus qu'il s'agit de flux monétaires internationaux, de l'expansion mondiale du néolibéralisme, d'une société en réseau et en même temps de la fin des Etats-nations et un rôle plus déterminant des corporations transnationales et de l'occidentalisation/américanisation du monde.

Quand on parle de l'influence de la mondialisation sur le genre, il peut y avoir l'idée simple que la société en réseau a un impact sur les 
rapports de genre ou que l'occidentalisation change les rapports de genre. L'idée est trop simple. C'est beaucoup plus complexe, car les changements peuvent être les conséquences de quelque chose d'autre.

Pour finir, j'aimerais attirer votre attention sur deux types de tautologie. D'une part, il s'agit du jugement de valeur sur la mondialisation. Si vous pensez que la mondialisation est un mal, la définition de départ est négative. Vous pourrez conclure que la mondialisation équivaut au capitalisme de casino, ce qui par définition est mauvais.

L'autre tautologie est que la mondialisation induit des inégalités. Mais les inégalités sont justement utilisées par le capitalisme pour élargir ses activités. Le capitalisme utilise les différences salariales pour s'installer dans un pays ou dans un autre, cherchant partout au monde des possibilités d'investissements. La mondialisation induit des inégalités, mais les inégalités sont à la base de la mondialisation.

Cet exposé met en perspective la discussion sur le premier énoncé:

\section{ENONCÉ 1}

Les inégalités économiques croissantes dans le monde et l'aug mentation de la pauvreté sont plutôt dues à des facteurs nationaux que mondiaux.

Vote: en désaccord: la grande majorité; d'accord: quelques-un-e-s.

Les membres Thais Corral (WEDO) et Bernard Kuiten (OMC) vont d'abord commenter cet énoncé.

\section{Thais Corral}

Introduction personnelle: je suis Brésilienne et pendant les seize dernières années, j'ai travaillé dans le domaine du genre. Mon travail consiste à jeter un pont entre les problématiques globales et 
locales, et inversement. Il y a douze ans, j'ai joint le débat sur la mondialisation grâce à WEDO (Women's Environment and Development Organization). A la fin des années 1980 et avec la montée de la société civile, un groupe de femmes issues de différents pays, qui avaient été actives dans la politique et dans les communautés, a profité de l'ouverture des Nations unies sur le débat de la limitation de la croissance et l'intégration des questions de l'impact sur le social et le développement, y compris les femmes et l'environnement. Les Nations unies annonçaient vouloir collaborer avec la société civile. Les femmes ont saisi l'occasion et ont essayé de mettre en avant les soi-disant problématiques de femmes (notamment pendant la conférence sur l'environnement à Rio en 1992).

La perspective sur le développement durable permettait une approche intégrée. Nous avons mis sur pied un mouvement, c'était une plate-forme d'action (l'Agenda des femmes 21). Cet agenda d'action nous a aidées à intégrer différentes perspectives du mouvement des femmes. Depuis lors, j'ai travaillé au Brésil pour des organisations à but non lucratif. L'une s'occupe de la communication et de l'utilisation de la radio pour donner une voix aux femmes et les rendre plus autonomes en leur donnant la possibilité d'exprimer leurs points de vue.

Au Brésil, nous avons essayé d'appliquer les acquis au niveau global au renforcement des compétences et des politiques nationales. Plus récemment, je fais partie - depuis 1995 - du World Forum 2000 auquel participent des anciens chefs d'Etat. Nous y entamons des dialogues entre les différents acteurs que Frans Schuurman vient de présenter. Au sein du World Forum 2000, un groupe de femmes veille à ce que les problématiques du genre soient intégrées.

Maintenant passons à ma réaction sur l'énoncé.

Je l'ai lu plusieurs fois pour me rendre compte de ce que je ressens. Cela a l'air simple. Ma première réaction est que je ne suis pas d'accord. Mais en fait je ne l'aime pas. Un tel énoncé blâme les victimes. 
J'ai trop souvent entendu que les gens qui sont les victimes d'un système, les pauvres, les femmes, sont responsables de ne pas avoir élu un bon gouvernement ou de bons représentants. Mais les processus politiques ont toujours une dimension historique et la situation n'est pas si simple.

Ma seconde réaction éclaire un autre côté. Prenons le Brésil, je pense que la libéralisation des années 1990 a eu un impact positif. Pendant des années, les inégalités étaient causées par la continuité $\mathrm{du}$ pouvoir des oligarchies et les subventions qu'elles recevaient. Cet argent était soustrait à l'investissement social. Ces oligarchies n'envisageaient pas de changer la base inégalitaire de la société. Dans ce sens, la libéralisation a induit une transparence sur la façon dont l'argent de l'Etat était dépensé et que c'était les oligarchies qui en profitaient le plus. Mais dans le cas de l'Argentine qui est en crise, on constatera le contraire. En Argentine, il y avait une classe moyenne importante, mais la libéralisation l'a détruite.

\section{Bernard Kuiten}

Introduction personnelle: Je travaille à la division des relations extérieures de l'OMC. Cette division s'occupe de toute relation de l'OMC avec l'extérieur: ONG, individus, parlementaires, hommes d'affaires, universitaires, etc. Nous sommes trois personnes dans cette division.

L'OMC est une organisation basée sur les accords légaux entre les 144 pays membres. Les pays membres doivent exécuter les règles et s'ils ne le font pas, ils auront des problèmes. Le secrétariat donne un soutien aux membres lors des négociations, analyses, recherches et dans leurs relations avec l'extérieur.

J'ai joint l'OMC en 1999 après avoir été négociateur de commerce pour les Pays-Bas et la Commission européenne. L'OMC ne dispose d'aucune compétence sur le lien entre le commerce et le genre. Cela n'a jamais été discuté. Les membres de l'OMC n'ont jamais revendiqué la discussion sur ce lien auprès du secrétariat. 
Quant à l'énoncé, il serait très facile pour moi d'être d'accord. Il s'agit de problèmes nationaux, les questions mondiales n'y ont rien à voir. C'est une combinaison de facteurs économiques et politiques. Je suis partiellement d'accord et partiellement en désaccord avec l'énoncé. On ne peut pas juste dire qu'il y a des inégalités économiques. Il faudra considérer des différents groupes de pays. Il y a eu des changements énormes les dernières années. Il faut donc regarder les différentes régions du monde et les situations particulières. Quels sont les facteurs nationaux: les politiciens, le monde des affaires, les syndicats? Ne devrait-on pas inclure également des facteurs géographiques et climatiques. Quand il y a un désastre naturel, qui en est responsable, le gouvernement ou les responsables d'un projet?

\section{Frans Schuurman}

L'énoncé se réfère à des gouvernements corrompus, ou à une élite nationale qui est responsable d'une mauvaise gestion économique, ce sont des filtres au travers desquels les facteurs mondiaux sont censés atteindre les bases d'un pays. C'est l'idée sous-jacente de cet énoncé.

J'ai vu des gens qui étaient en faveur de l'énoncé. Quelqu'un veut-il le développer?

\section{Fenneke Reysoo}

La mondialisation en soi est une abstraction. J'adhère aux théories qui mettent en avant les relations de pouvoir entre acteurs. Le mondial ne peut être observé qu'au niveau local (national, régional ou communautaire). Le niveau national est un révélateur. C'est à ce niveau-là que se discutent et se font les politiques sociales et industrielles. Chaque gouvernement joue un rôle important pour intégrer les problématiques mondiales dans les politiques nationales. Les relations de pouvoir entre acteurs, le lien entre le mondial et le national, s'observent donc là où les acteurs se rencontrent, que ce soit lors des conférences des Nations unies, des négociations de l'OMC, des rencontres ministérielles ou lors d'une réunion des anciens au village. 


\section{Bene Madunagu}

Les gouvernements nationaux sont inscrits dans une histoire de colonialisme et d'esclavage. Les gouvernements nationaux nous sont imposés.

\section{Frans Schuurman}

Où est la limite du rôle du colonialisme? Est-ce que le colonialisme est responsable de la corruption des gouvernements? Ne glisse-t-on pas vers un déterminisme historique et ne s'éloigne-t-on pas de la capacité d'action des acteurs (agency)?

\section{Shahra Razavi}

Revenons vers le début des années 1980. On n'a pas besoin de remonter à l'époque du colonialisme. Les pays endettés ont dû se tourner vers le FMI pour demander des prêts. Il y a eu des politiques de conditionnalité liées aux prêts. Les pays étaient forcés d'adopter des politiques qu'ils n'auraient peut-être pas adoptées par eux-mêmes. Dès ce moment, tout ce qui s'ensuit n'est plus vécu comme relevant de la responsabilité des gouvernements, car ils ne se sentent pas responsables de ce qui se passe. Nous savons que ces politiques n'étaient pas un vrai succès dans les secteurs sociaux ou pour l'égalité des genres. Ils n'ont pas non plus été une réussite économique. La question des responsabilités dans le cas des pays endettés qui étaient obligés de demander des prêts doit être abordée avec prudence. Ces pays ont adopté des politiques qui ne relèvent pas de leur seule responsabilité. Et ces processus, on les observe dès les années 1980.

Ce n'est pas nécessairement parce que les gouvernements étaient corrompus que les pays se sont endettés. Je ne remets pas en question que les problématiques mondiales sont filtrées par les situations nationales. Dans un pays où il y a une oligarchie terrienne, la libéralisation des terres se passera différemment que dans un contexte d'égalité. Bien sûr, la mondialisation passe toujours par des institutions nationales, des histoires nationales et les forces sociales. L'énoncé pose problème, parce qu'on ne peut pas généraliser. En 
même temps, si les inégalités augmentent dans les trois quarts des pays de notre planète, $\mathrm{y}$ compris là où il $\mathrm{y}$ a des bonnes institutions nationales, des Etats-providence et des structures de classe relativement égalitaires, il devra y avoir des explications qui vont au-delà des facteurs nationaux. Il doit y avoir quelque chose qu'il n'y avait pas avant et qui doit se passer au-delà des Etats-nations. C'est une suite logique. Alors c'est un argument pour l'explication mondiale.

\section{Isabel Rauber}

Nous sommes prisonnières de concepts qui cachent le monde réel dans lequel nous vivons. Quand on parle de mondialisation dans les pays pauvres, nous parlons du pillage de nos pays et de l'atrophie de nos possibilités. Nos systèmes de production ont été cassés. Et quand on parle de production, on parle de la vie. La mondialisation, l'OMC, le FMI sont derrière. On ne peut parler de tout ceci sans les mentionner. La dichotomie national-mondial est fausse. Nos gouvernements nationaux sont complices de processus plus larges.

\section{Frans Schuurman}

Après ce premier tour de la discussion, je vous prie de revoter. Trois personnes ont changé d'avis, elles étaient d'accord et maintenant en désaccord.

\section{ENONCÉ 2}

L'économie mondialisée est basée sur les constructions domi nantes du genre afin de maximiser les bénéfices. Autrement dit les inégalités de genre sont bénéfiques à l'économie mondialisée.

Vote: la quasi-majorité est d'accord avec cet énoncé.

Mascha Madörin et Naoko Otobe vont donner leur avis.

Mascha Madörin

Introduction personnelle: l'année dernière, je travaillais avec une 
petite ONG sur les banques suisses dans les pays en voie de développement. Il y avait un lobby pour bloquer les avoirs de Mobutu et un groupe de pression pour questionner le rôle des banques suisses en Afrique du Sud pendant le régime de l'apartheid. Il y a très peu de femmes dans le monde des ONG, du gouvernement ou des mouvements sociaux qui travaillent sur ces thématiques. Le 7 mars 2001, nous avons établi un programme de dix points pour le Secrétariat d'Etat à l'économie (seco). Jusqu'à ce jour, seulement $1 \%$ de nos demandes a été pris en considération. Il nous faut donc continuer à travailler ensemble. Une de nos demandes est d'avoir des personnes qualifiées en genre dans les délégations et organisations suisses à l'étranger. Nous demandons un compte rendu des discussions sur le genre au sein des organisations comme l'OMC, le FMI, etc. On leur demande que leur staff soit compétent et qu'ils rendent public ce qui est connu sur le commerce international du point de vue du genre afin que nos parlementaires, notre gouvernement et un public large soient informés.

Nous remarquons des limitations intellectuelles. La plupart des gens pensent que le genre concerne des questions culturelles ou sociales, mais ils ne l'associent pas à l'économie. Il est de ce fait très difficile de parler du genre au niveau macroéconomique.

Ce que je pense de l'énoncé. Méthodologiquement, l'énoncé me pose problème. S'il s'agit d'une prise de position politique, je n'y vois pas de problème. Je peux accepter que l'économie mondialisée est basée sur les constructions dominantes du genre. Mais je ne suis pas d'accord avec la finalité «afin de maximiser les bénéfices». En même temps, il n'y aurait pas une telle accumulation mondiale, s'il n'y avait pas une économie genrée.

Les mots «autrement dit» sont additionnels. Les inégalités de genre bénéficient aux élites du marché, ce qui n'est pas la même chose. Je voudrais ajouter une phrase: par conséquent, il est difficile de changer les rapports de genre en faveur des femmes. Laissez-moi m'expliquer. 
Ce matin, lors des exposés il y avait une absence de perspectives théoriques. Ce n'est pas une question d'absence de recherches, mais un problème de manque de théories. Il est urgent d'élaborer une économie politique de la domination masculine. Il faut problématiser l'accumulation, un terme que je n'ai pas entendu ce matin. On parle souvent des femmes et du microcrédit, mais on ne parle jamais de l'accumulation et du contrôle de l'accumulation. Un grand problème du microcrédit est son lien avec le système bancaire formel et mondialisé. Y a-t-il un flux de capitaux vers ce système? Comment organiser le système des microcrédits de façon à ce que les bénéfices restent entre les mains des femmes. Il faut se poser ce type de questions. Il n'y pas une théorie économique sur les dynamiques de l'accumulation et du genre, de la mondialisation et l'économie des soins (economy of care). Beaucoup de thématiques méritent d'être intégrées dans les catégories et modèles économiques.

J'ai fait une analyse de l'élite du marché mondial. Les participants au Forum économique mondial à Davos sont au nombre de $90 \%$ d'hommes, dont $90 \%$ viennent des Etats-Unis, de l'Europe et quelques-uns du Japon. Un tout petit pourcentage d'hommes du Sud font partie du groupe des leaders mondiaux et aucune femme, ni de Suisse, ni d'Europe, ni des Etats-Unis. En analysant la composition de la Marche mondiale des femmes, il y a 30\% de femmes des pays du Nord et les autres 70\% sont des femmes du Sud et de $l^{\prime} E s t$. Les ONG sont donc différemment mondialisées que les élites du marché mondial. Il faut analytiquement tenir compte de ces deux types de mondialisation.

\section{Frans Schuurman}

C'est bien que vous mentionniez le besoin de théorisations. Un autre chiffre est que 25 à 30\% du commerce international a lieu au sein de la même entreprise multinationale. Ce qui veut dire que l'entreprise mère traite avec ses entreprises filles, et que les théories économiques existantes ne rendent pas compte de ce phénomène. Il y a un besoin pressant de nouvelles théories économiques. 


\section{Mascha Madörin}

Si vous me permettez de revenir à la première discussion sur les facteurs nationaux et internationaux: si nous regardons ce que le système bancaire suisse fait avec le transfert des prix pour les compagnies étrangères. Nous avons tant d'argent qui devrait se trouver en Afrique, en Asie, en Amérique latine ou dans les pays de l'Est. Il m'est difficile en tant que Suissesse de parler des élites corrompues dans les pays du Sud.

\section{Naoko Otobe}

Introduction personnelle: l'OIT, où je travaille, est une organisation basée sur les droits. Il existe 183 conventions internationales sur le travail, y compris celles concernant l'égalité de genre, la liberté d'association, la négociation collective, la santé et la sécurité professionnelles, bref tout ce qui relève du droit de travail. L'OIT s'adonne à la promotion des normes internationales de travail. Au sein du système des Nations unies, l'OIT est unique dans la mesure où il s'agit d'un partenariat tripartite: les décideurs viennent du patronat, des syndicats et des gouvernements. Les discussions se font au sein de cette structure tripartite. L'OIT a quatre objectifs stratégiques: 1) la promotion des principes et droits de travail, 2) la promotion de l'emploi, pour les hommes et les femmes, 3) les systèmes de protection et de sécurité sociales, 4) la promotion du dialogue social. L'OIT a une politique de mainstreaming du genre, aussi bien quant à la structure que quant au personnel. Il y aussi un programme sur le Travail décent: liberté, équité et dignité. Je travaille depuis plus de dix ans à l'OIT, tout spécialement sur l'impact genré des politiques macro-économiques sur le travail et l'emploi. Plus récemment, j'ai participé à des recherches sur l'impact de la crise économique aux Philippines et autres pays asiatiques.

Ma réaction à propos de l'énoncé. C'est intéressant de voir que la quasi-majorité est en accord avec la thèse. J'aurais voulu être entièrement d'accord, mais je ne suis pas sûre de pouvoir l'être. De mon point de vue, la construction du genre est un facteur qui influence le système économique. Ce n'est donc pas la même chose que de dire 
que l'économie est basée sur la construction dominante du genre. Les systèmes économiques actuels essaient d'exploiter les femmes pour maximiser les bénéfices. Il ne s'agit pas seulement des femmes, mais également des groupes minoritaires et des jeunes. Le marché fonctionne selon la loi de l'offre et de la demande et celle-ci est indifférente au genre ou aux problèmes sociaux. Nous essayons de modérer les processus du laisser-faire en promouvant l'égalité des droits au niveau national. Si les employeurs et employés sont plus conscients de la question de l'égalité des droits, cela pourra se traduire en de meilleures opportunités de travail et l'amélioration des conditions de travail. Les salaires des hommes et des femmes seraient égalisés et tous les partis seraient gagnants. Cela peut paraître utopique, mais je trouve exagéré de dire "afin de maximiser les bénéfices» en soi. Bien que dans certains cas, les femmes soient désavantagées à cause de leurs moindres instruction, alphabétisme et compétences. C'est la raison pour laquelle il est nécessaire de promouvoir l'égalité des droits, ce qui pourrait modérer les processus du marché libre.

\section{Frans Schuurman}

Merci beaucoup. Maintenant, la parole est au public.

\section{Genoveva Tisheva}

Le fait que la Banque mondiale et l'OMC ne travaillent pas avec le genre, le fait qu'il existe des stéréotypes et la ségrégation de l'emploi, qu'est-ce que cela signifie? Les acteurs de la mondialisation ne prennent pas en considération le genre. Cela veut dire que l'on condamne les systèmes plus ou moins égalitaires qui existent déjà dans certains pays. En Bulgarie, par exemple, ils se sont mis d'accord pour condamner la régulation des normes de travail.

\section{Bernard Kuiten}

Je vous prie de ne pas mettre tout le monde dans le même panier. L'OMC ne doit pas être confondue avec le FMI ou la Banque mondiale. L'OMC ne s'occupe pas des questions de genre, parce que aucun pays membre ne les a introduites. Les participants parlent des règles générales des négociations intergouvernementales sur le com- 
merce, ils ne traitent pas des aspects pratiques des projets comme le font le FMI ou la Banque mondiale. Il est imaginable que dans les négociations sur la libéralisation du secteur des services, un pays aimerait protéger ce secteur de l'extérieur pour des raisons de genre. Mais ceci ne sera pas statué dans les documents légaux de l'OMC. Il est théoriquement très difficile d'intégrer un argument se référant au genre dans le contexte légal de l'OMC. Nous discutons de cette thématique avec certaines ONG. Si vous avez un cadre théorique pour l'OMC ou pour les gouvernements, il y aura peut-être une ouverture, mais jusqu'à maintenant un tel cadre légal fait défaut.

\section{Ewa Charkiewicz}

J'aimerais dire quelque chose sur la différence entre l'OMC, la Banque mondiale et le FMI. Lorsque l'OMC a été fondée à Marrakech, il y a eu des accords de cohérence entre les trois. Tout spécialement les pays en voie de développement ont intégré la politique de la libéralisation du commerce dans leurs stratégies pour réduire la pauvreté. Il y a actuellement une nouvelle sorte de colonialisme suite à ces accords de cohérence et ces cadres intégrés. Insister sur leurs différences ne rend pas justice à la réalité. Les pays endettés n'ont pas beaucoup d'espace de manœuvre.

L'autre chose concerne l'énoncé et la construction dominante du genre. Aujourd'hui nous avons beaucoup parlé des femmes, mais nous oublions de mentionner les hommes. Les masculinités ont été transformées par la mondialisation. D'un côté, il y a l'homme de Davos, et de l'autre côté, l'homme d'El-Qaida. La capacité d'action (agency) exprimée par l'homme d'El-Qaida est proche de la construction masculine des hommes qui vivent un licenciement, qui sont obligés d'accepter un emploi dit féminin - souspayé - les hommes russes qui n'arrivent pas à l'âge de la retraite ou ceux qui vivent un désarroi identitaire. La mondialisation a une retombée sociale très lourde sur les hommes. Les masculinités sont reconstruites et nous assistons à l'émergence de masculinités, telles que l'homme de Davos. Il est capable d'action dans le contexte de la mondialisation. Il maximise ses bénéfices et accélère les processus de 
production et de consommation pendant que les coûts sociaux et environnementaux sont déchargés sur les femmes. Quand elles sont déchargées et quand elles ne sont plus partagées, les responsabilités demeurent inégales. Les rapports de genre restent hiérarchiques et un tel type de masculinité dominante ne permet pas de réaliser le partenariat. Qu'il s'agisse de l'homme d'El-Qaida ou de l'homme de Davos, il n'y a pas de partenariat. Une condition préalable pour changer la position des femmes est qu'elles puissent devenir des partenaires.

On repasse au vote: deux personnes ont changé d'avis.

\section{ENONCÉ 3}

Les marchés ouverts et le libre commerce, bien qu'ils semblent offrir des opportunités à certaines femmes, marginalisent les gens du pouvoir de décision concernant leurs vies.

Vote: la majorité est d'accord.

Jean François Giovannini

Introduction personnelle: jusqu'en juillet 2001, j'étais le directeur suppléant à la Coopération suisse au développement. J'ai participé à la politique internationale et représenté la Suisse à Rio, au Caire et à Copenhague. J'ai été régulièrement membre des délégations suisses. Nous avons toujours essayé de relayer les propositions lorsque des organisations féministes nous en ont présenté. Nous avons travaillé sur une base régulière avec les organisations qui travaillent sur la problématique des femmes. La DDC connaît une politique genre depuis une vingtaine d'années. Cette politique se développe comme elle se développe dans le monde. Au début c'était des interventions en faveur des femmes et par la suite c'était des analyses plus complètes. Nous avons un excellent service genre. La mise en œuvre pratique se heurte à beaucoup de problèmes. D'abord des problèmes de staff, tout le monde est d'accord sur le principe, mais la 
réalité n'est pas facile. Puis dans les pays dans lesquels nous travaillons, nous rencontrons beaucoup de résistances. Les résultats sont encore très partiaux.

En ce qui concerne la globalisation, $\mathrm{j}$ 'aimerais faire une remarque générale. Il est très difficile d'utiliser un langage général pour une réalité aussi complexe. J'adhère plus ou moins à ce qui a été dit ici. Mais il est nécessaire de nuancer. Je pense que nous n'avons pas vraiment le choix, la globalisation est un fait incontournable. Très peu de pays ont vraiment une option. Quelques pays échappent à la globalisation, quelques-uns ont fait un choix d'être hors du système ou on a fait le choix pour eux (l'Iraq, la Corée du Nord, Cuba, la Birmanie, l'Afghanistan). Seuls de très grands pays ont la possibilité de limiter leur insertion dans l'économie globale, comme la Chine ou les Etats-Unis. Les Etats-Unis pourraient quitter le système global. Leur commerce extérieur ne représente pas une grande partie de PNB, leur dépendance n'est grande que pour l'approvisionnement en pétrole. Mais pour un petit pays comme la Suisse, il n'y a pas une option réelle. Nous ne sommes pas autosuffisants. La globalisation est un système qui existe, qu'on ne peut supprimer, mais il est évident qu'il est bien qu'imparfait de par sa nature. Comment pouvons-nous créer un système social pour les plus défavorisé-e-s?

A Doha, nous avons entendu certains pays se plaindre. On a promu la libéralisation, mais la résistance est venue surtout des pays du Nord. Ceux-ci ont moins ouvert leurs frontières que les pays du Sud. La Suisse devrait être plus consciente de cette problématique Nord-Sud dans ses négociations prochaines. La réalité politique est que les ONG sont en train de revendiquer un système plus égalitaire, mais en même temps il y a le pouvoir politique et les intérêts économiques. Ceci résulte en des contradictions. Dans le domaine de l'agriculture suisse, par exemple, la Suisse n'est pas prête à ouvrir ses frontières.

Cela relève de la responsabilité des agences comme la DDC et de celle des personnes comme moi, de renforcer la capacité de dialogue 
des femmes, renforcer la société civile, des organisations féminines, participer à l'élaboration de systèmes politiques plus démocratiques. L'OIT établit par exemple des règles internationales, nous devons appuyer la lutte contre le travail des enfants, contre la violation des standards internationaux et la coopération économique et environnementale. Cela peut avoir un effet positif sur d'autres pays et sur les groupes marginalisés, y compris les femmes. Au niveau national, nous pouvons canaliser ces efforts.

\section{Bernard Kuiten}

J'ai de la peine à comprendre comment des marchés ouverts ou le libre commerce marginalisent les gens des processus de décision. Je retournerai l'argument: dans quelle mesure les gens sont-ils marginalisés dans la prise de décision sur la libéralisation du commerce? C'est une bonne question, car elle vaut pour le Nord aussi bien que pour le Sud. Le problème est que les marchés ouverts et le libre commerce sont des choses auxquelles on s'est habitué depuis les cinquante dernières années, dans tous les cas avec le GATT. Plus récemment, le débat s'est porté vers l'évaluation du néolibéralisme et des marchés ouverts. Est-ce qu'ils sont les meilleurs moyens pour induire le progrès économique et le développement durable?

Il faut donc se demander dans quelle mesure les gens sont impliqués dans la prise de décisions sur les politiques de commerce par leurs gouvernements. On vient de discuter de la démocratie. L'OMC ne peut qu'accepter la situation actuelle et les prises de position des gouvernements membres. Les réunions de l'OMC se déroulent démocratiquement. Il n'en va pas de même en amont dans chaque pays où il y a des élites dans des positions dominantes.

\section{Thais Corral}

Les institutions internationales ont des positions très ambiguës. Elles ont beaucoup d'influence sur ce que les pays font. Quand les choses ne se font pas comme elles le souhaitent, c'est la faute des pays, quand les choses répondent aux intérêts des organisations, elles ont les outils pour les pousser jusqu'au bout. C'est ambigu et 
controversé. La Banque mondiale a organisé des écoutes publiques (public hearings) avant d'initier un projet. Ces évaluations étaient très vagues, on ne parlait pas vraiment des vrais problèmes. Il fallait juste respecter la procédure bureaucratique. Ce n'est que récemment que les gens et les communautés concernés ont été capables de s'organiser, de se faire entendre et de comprendre comment influencer les processus de prise de décisions. Actuellement, il n'y a plus d'écoutes publiques. Il y a une responsabilité pour s'assurer de l'implication des gens. Les grandes organisations devraient assumer cette responsabilité, surtout là où il n'y a pas une véritable société civile.

Une autre chose, l'OMC compte 144 membres, mais il n'y a que 12 femmes représentantes. Ceci n'est plus du tout acceptable pour une organisation mondiale. Après toutes les conférences dans lesquelles l'égalité du genre a été mise en avant. Si les pays ne présentent pas de femmes, il faut les y obliger, comme vous les obligez à faire d'autres choses.

\section{Christine Verschuur}

Je doute du fonctionnement démocratique de l'OMC, il n'y a guère de femmes présentes lors des négociations. Deuxièmement, je pense qu'il nous faudra examiner le type de mondialisation que nous souhaitons. L'Unesco, par exemple, prône une mondialisation à face humaine. Nous sommes tous égaux, mais certains plus que d'autres semble être la devise. Les règles de la mondialisation devraient s'appliquer à tout le monde. On a besoin de règles pour "contrôler» la mondialisation. Troisièmement, il existe tout de même un nombre de théories économiques féministes sur l'économie des soins ou la reproduction sociale. Les Etats devraient en prendre connaissance et les intégrer dans leurs politiques.

\section{Silvia de Zordo}

$\mathrm{Au}$ niveau du vécu des femmes, nous voyons qu'elles sont plus mobiles et qu'elles ont des possibilités de travail. Une étude sur les immigrées en Italie, originaires des pays de l'Est ou d'Amérique latine, nous montre qu'il ne s'agit guère de choix. Ces femmes dans 
le besoin quittent leur famille et leur pays à un âge très jeune. Elles n'ont pas vraiment d'alternative. Que font ces femmes en Italie? Elles font le travail de reproduction sociale, car l'Etat ne dispense pas tous ces services sociaux. Ces jeunes femmes n'ont pas de droits, elles sont étrangères et souvent elles sont victimes de violence. Cette internationalisation du travail aliène beaucoup de femmes de la prise de décisions sur leurs vies et leurs corps.

Vote: personne n'a changé d'avis.

Passons maintenant aux questions concernant la pratique.

Que doit-on faire?

\section{ENONCÉ 4}

Avec la forme actuelle de la mondialisation, il n'y a plus de rôle pour la coopération au développement.

Vote: la majorité est en désaccord.

\section{Jean François Giovannini}

Comme représentant d'une agence de coopération au développement, j'ai toujours pensé que la coopération au développement, surtout bilatérale, n'est qu'un pis-aller. Ce n'est pas un bon système. On devrait d'abord avoir un système équitable sur le plan du commerce international, qui permette à tous les pays de gagner honnêtement leur vie au niveau international, ouvrir les marchés, mettre fin aux subventions agricoles, etc. Et peut-être un système des Nations unies pour certaines tâches particulières, par exemple la formation que l'Unesco pourrait dispenser. Malheureusement, la réalité politique est que seule la coopération bilatérale a un appui politique substantiel dans les pays du Nord, et encore, car aux Etats-Unis ce n'est même plus le cas. C'est beaucoup plus difficile d'obtenir un assentiment politique pour des concessions importantes sur le plan commercial. 
Les ONG ont la tâche d'inventorier les contradictions entre ce qui est et ce qui devrait se faire. Elles doivent conscientiser un large public sur le problème et réfléchir sur un système global qui sera avantageux pour tous les pays.

\section{Mascha Madörin}

Je suis d'accord avec ce qui vient d'être dit. Nous devons faire la différence entre les projets de développement locaux et les politiques économiques au niveau international. Les projets de développement sont un travail de renforcement ou un travail social. Le mot coopération internationale au développement est faux. Nous sommes dans une réalité d'aide au développement. Il faudra inventer une nouvelle politique internationale.

\section{Frans Schuurman}

La coopération internationale au développement était soit bilatérale, soit dirigée vers la société civile. Une des essences de la mondialisation est la fin de l'Etat-nation. Les gouvernements nationaux ont de moins en moins de pouvoir de décision sur ce qui se passe sur leur territoire. C'est peu efficace de les élire comme partenaires de la coopération au développement. Les projets dirigés par la société civile ont de plus en plus le caractère de l'aide d'urgence qu'un soutien structurel pour aller de l'avant. Quel rôle peut jouer la coopération internationale?

\section{Bene Madunagu}

J'aimerais dire que ce n'est pas nécessairement la forme actuelle de la mondialisation qui devrait être la base de la coopération internationale au développement. Il devrait y avoir une coopération entre gouvernements basée sur la transparence, la démocratie et le bienêtre des gens défini par eux-mêmes. Ce n'est pas forcément la forme actuelle qui est la meilleure.

\section{Wendy Harcourt}

Derrière l'énoncé, il y a la crainte de beaucoup d'individus et d'organisations qui savent quels sont les problèmes: pauvreté, inégalité 
de genre. Ils se rendent comptent qu'ils sont impuissants pour faire quoi que ce soit. Le système des Nations unies et la façon dont il est organisé ne leur permet plus d'être les acteurs principaux. L'OMC, la Banque mondiale, le FMI et les pouvoirs cachés sont les acteurs principaux actuellement. La coopération internationale a vu le jour il y a quarante-cinq ans dans un monde complètement différent. A l'heure actuelle, quelles sont les institutions qui vont réaliser ce que nous souhaiterions tous: égalité, justice sociale... non seulement entre les pays, mais également à l'intérieur de ceuxci ? Par-dessus le marché, il y a la question du financement du développement. Cela coûte beaucoup d'argent et nous ne disposons pas des cadres pour avoir cet argent. Les personnes réelles qui prennent les décisions sont également impuissantes. Le système ne fonctionne plus, il y a des gens qui se sont dévoués pour la coopération durant toute leur vie. C'est une question difficile à laquelle je n'ai pas de réponse. Est-ce que la solution est Porto Alegre? Je ne le pense pas, mais on peut en discuter. Toujours est-il que dans tout cela, on ne discute pas du genre. Est-ce que Porto Alegre va mettre en avant les questions de l'égalité du genre? Nous connaissons l'homme de Davos qui ne tient pas compte du genre, mais dans le camp de Porto Alegre, il y a autant d'hommes qui n'y accordent pas d'importance.

\section{Thais Corral}

J'aimerais continuer sur ce que Wendy vient de dire. Nous répétons beaucoup de choses. Quel impact a eu la coopération internationale? Beaucoup d'argent reste à des niveaux intermédiaires et n'arrive pas aux populations dans le besoin. Porto Alegre est une expression de la société civile, mais avec des objectifs contradictoires. Le genre est choisi comme thème transversal cette année - 2002. C'est le résultat du travail en réseau mondial.

\section{Mascha Madörin}

Je travaille avec des réseaux internationaux et sur les politiques économiques internationales. Si je regarde Attac et d'autres mouve- 
ments qui voient le jour, j'ai une impression de déjà-vu. C'est comme dans les années 1970 en ce qui concerne les perspectives théoriques. Cela ne dépasse pas le point de vue des hommes qui s'imaginent ce que sont les questions féministes. Il en va de même pour le mouvement anti-mondialisation. Il existe des théories beaucoup plus avancées, mais je ne les entends nulle part. A chaque fois, on réinvente la roue, nous discutons comme dans les années 1970 et à vrai dire cela me fatigue.

\section{Bernard Kuiten}

L'OMC ne gère pas de projets et n'est pas un bailleur de fonds. Les trois dernières années, cependant, et surtout après Doha, beaucoup d'argent a été investi dans l'assistance technique et le renforcement des compétences. Les demandes viennent des pays en voie de développement et les finances des ministères de la coopération des pays développés. Ces derniers ont tendance à attribuer de plus en plus d'argent à l'OMC. Il ne s'agit pas de savoir ici, si c'est bien ou mal. Mais si l'on pense que l'OMC est quelque chose qui incarne le mal, on peut se poser la question pourquoi la coopération internationale au développement s'intéresse à contribuer à l'assistance technique à travers l'OMC? Toutefois, il ne s'agit pas de sommes d'argent énormes comparées au budget total.

\section{Naoko Otobe}

L'OIT essaie actuellement de promouvoir sa Déclaration sur les principes et les droits fondamentaux du travail (les conventions des droits fondamentaux comprennent l'égalité, l'élimination du travail des enfants, négociations collectives, et liberté d'association). Le Sommet social a mis ces conventions en avant comme étant fondamentales. Ce n'est pas l'OIT qui a décidé qu'elles étaient fondamentales. Actuellement, l'argent est attribué à la réalisation des conventions, telles égalité du genre, travail des enfants, travail forcé. L'OIT veut promouvoir des droits dans le contexte du développement. Par exemple l'OIT veille sur l'application de ces principes et droits fondamentaux dans les projets mis en œuvre dans les zones industrielles pour l'exportation. Il faudra voir quel impact peuvent avoir 
de tels projets. Je suis en désaccord avec l'énoncé. Nous pouvons continuer de promouvoir l'égalité de genre dans le domaine du travail par l'approche basée sur les droits.

\section{Frans Schuurman}

En fait, l'existence de régimes non démocratiques est favorable à l'aide au développement. Après le changement des régimes dictatoriaux en Argentine et au Chili, les nouveaux gouvernements ne voulaient plus de l'aide au développement de l'Europe. L'absence de démocratie est la raison d'être de la coopération au développement.

Vote: un changement d'opinion.

\section{ENONCÉ 5}

Les actions ayant pour intention d'influencer les politiques d'éga lité de genre et de développement durable ne devraient plus se limiter aux questions de genre et développement, mais viser les institutions financières internationales et $s^{\prime}$ étendre aux relations politiques internationales (BM, FMI, OMC).

Vote: tout le monde est d'accord.

\section{Mascha Madörin}

En Suisse, il y a eu une grande campagne pour savoir si la Suisse allait rejoindre la Banque mondiale et le FMI. Notre réussite a été que la loi sur la coopération au développement doit être appliquée à la Banque mondiale et le FMI. Nous recevons des rapports sur les politiques de la Banque mondiale, mais pas du FMI. Il est certain qu'ils pensent que le genre se réfère aux rapports sociaux ou à des questions locales, mais que ce n'est pas pertinent pour les politiques macroéconomiques. On croit généralement que les affaires financières et bancaires n'ont rien à voir avec le genre. Il faudra évacuer ce préjugé. Le niveau théorique dans les formations universitaires laisse à désirer. Il faut vraiment rendre les études d'économie dans les universités suisses plus sensibles aux questions de genre. 


\section{Frans Schuurman}

En effet, il y a un écart énorme entre les universitaires et les opérationnels du développement. En plus, un grand nombre de gens formés en sciences sociales sont cooptés par la Banque mondiale.

\section{Mascha Madörin}

Et en Suisse, il y a aussi un écart entre la politique étrangère et la politique de la coopération au développement. Le débat continue. De même entre économistes et sociologues. L'économie du développement n'est pas prise au sérieux par les économistes. Ne parlons pas de l'économie féministe. C'est un sport professionnel auquel ne participent que $10 \%$ de femmes. Trop peu d'économistes la prennent au sérieux, et ils ne sont pas disposés à l'intégrer dans leur travail. Ces séparations sont de véritables obstacles.

\section{Jean François Giovannini}

J'aimerais introduire l'image de la corrida. Les institutions internationales sont un peu comme le linge rouge qui sert à tromper le taureau. Les vrais décideurs, ce ne sont pas les organisations internationales, ce sont les gouvernements. Et certains gouvernements plus que les autres, car ils ont des positions de pouvoir dans les institutions. Cela les arrange de dire que c'est la faute au FMI ou à la Banque mondiale. Les vrais responsables sont dans le Congrès des Etats-Unis. C'est là que se situe la résistance au changement et c'est là qu'il faudra faire du lobby. Si le Congrès américain prenait des positions plus fortes, ces organisations changeraient facilement. Il ne faut pas blâmer ces institutions, car elles n'existent pas par elles-mêmes.

Il faut travailler à partir des gouvernements. Nous pouvons continuer d'accuser la Banque mondiale, mais si l'on n'analyse pas où se trouvent les vrais centres de pouvoir, on n'avancera pas. Le vrai pouvoir se trouve à Washington, non pas à la Banque mondiale, mais au Congrès américain. 


\section{Bernard Kuiten}

Il n'y a aucune discussion sur le genre au sein de l'OMC. Comment pourra-t-on intégrer des réflexions sur le genre dans les règles légales de l'OMC? Il en va de même avec le débat sur les droits humains. Il y a deux ans environ, les ONG ont introduit le débat sur le commerce et les droits humains. Comment tient-on compte des droits humains dans les règles légales? On peut l'introduire dans le préambule, mais ce n'est pas «contraignant». A Doha, nous avons pour la première fois essayé de jeter un pont entre le commerce et l'environnement. Il a fallu sept ans pour en arriver là.

\section{Frans Schuurman}

Je me demande si c'est de la théorie qu'il faut ou de la volonté politique.

\section{Silvia Federici}

J'ai trop souvent entendu cet argument que la situation est inéquitable et que les relations commerciales sont ce qu'elles sont parce que le Sud le veut. On ne peut soi-disant pas abolir le travail des enfants, parce que les pays ont besoin de cette main-d'œuvre (Inde, Pakistan). Le FMI se plie à ces besoins, ce qui n'est pas approprié. Il faudra analyser pourquoi ces pays ne peuvent pas abolir le travail des enfants. Il en résulte probablement qu'ils sont mains et pieds liés.

\section{Chrystel Ferret}

Il existe un nombre de cadres théoriques élaborés par les économistes féministes, mais ils ne sont pas utilisés. Les budgets genre ne sont pas pris au sérieux par la DDC. C'est partiellement dû à l'ignorance. Nous pourrons en tant que citoyens interpeller le gouvernement. Par la participation aux réseaux internationaux, nous pouvons également organiser le lobby.

Il y a eu des progrès, mais il faudra un suivi. Il y a des cadres pour les budgets genre; il faudra attirer l'attention des collègues hommes. Il faut travailler le mainstreaming. Si le gouvernement ne fait pas d'effort, l'OMC ne changera pas. C'est une question politique. 


\section{Fenneke Reysoo}

Quelques mots pour clore le débat. S'il y a une ligne conductrice qui revient dans les discussions des cinq énoncés, c'est que la thématique de l'économie mondialisée et son impact sur le développement social et les questions de genre est un sujet très vaste. A chaque reprise, on a insisté qu'il faudra préciser de quels processus on parle. S'agit-il d'indicateurs, de causes ou de conséquences? Il est important de tenir compte des contextes historiques, politiques et culturels quand on veut analyser l'impact de l'ouverture des marchés et du libre commerce sur le statut et la position des populations défavorisées. Le dilemme de la croissance est apparu à plusieurs moments: bien qu'il y ait un besoin de croissance économique, sur le terrain nous voyons les conséquences négatives sous la forme de dépendances et d'exploitations induites par les forces des marchés nationaux et internationaux qui sont aveugles aux dimensions de la justice sociale et de l'égalité des genres. Les participant-e-s à notre table ronde nous ont fait part de leurs points de vue et la diversité de ceux-ci a permis des échanges intéressants. Nous espérons sincèrement que le débat vous a aidés à affiner vos réflexions. Tout en vous souhaitant bonne continuation dans vos travaux ultérieurs, je vous remercie de votre participation. 


\title{
GLOBAL ECONOMY AND GENDER IDENTITIES, A ROUND TABLE DEBATE
}

\author{
Summarized transcription by Fenneke Reysoo
}

\section{Objectives of the Round Table}

We expect from the participants to the debate to give a short presenta tion of their organization and then their vision and comments on five statements that will be introduced by the chairman Frans Schuurman. The discussion on each statement will be preceded by a vote among the audience. After the presentation of the visions of the participants of the Round Table and mutual comments on each other's visions, the audi ence will vote again in order to see if the discussions and various points of view had an influence on the initial opinions held.

\section{INTRODUCTION}

\section{Globalization Issues AND Pitfalls}

\section{Frans Schuurman}

CIDIN (Centre for International Development Issues Nijmegen, the Netherlands). ${ }^{1}$

1 Frans Schuurman (ed.), 2000, «Globalization and Development Studies: Challenges for the 21st century». Amsterdam: Thela Thesis. 
What do we mean by globalization? There are various positions taken in the global debate. It is important to be aware of the various positions taken on globalization before entering the debate. Let me present a simplified taxonomy of globalists.

- True globalists. They say that globalization is not the same as late modernity, it is an entirely new epoch.

- Cyberspace globalists. They actually say the same, but they insist on the fact that cyberspace makes it a new epoch.

- Non-globalists. They say that globalization is nothing new, there was an expansion of imperialism between 1870 and 1914 as it occured since 1985. Nothing new, just an other expansion wave of capitalism and imperialism.

- Marxist point of view: globalization is capitalism gone global

- Post-globalists. Their opinion is that if we have ever seen a period of globalization it is over now. Because what we see now is neolocal tribalism and universalism is on the decline. Nation States fall apart and form new entities on the basis of non modern neo-tribal identities.

There is another possible taxonomy in the globalization debate based on whether you think it is good or bad. We have the positivists who say that it is system-led. This is an important point of view. Because it means that it can not be stopped, that there is a system out there - either technology, capitalism or imperialism. They say there is no alternative, no use fighting it, just go with the flow. It is system-led.

The anti-globalists say that it is bad and that it is agency-led. Which means that there are particular agents in the world system that can be hold responsible for the globalization process. Which is an entirely different point of view than when you say it is systemled. Because when you say that it is agency-led you can hold certain agents responsible for either the good or the bad things - in this case the bad things - of globalization. 
We have the reformists who say that we have to strive for a sort of global keynesianism to fight the bad things of globalization. It is essentially good, but there are some bad elements which have to be fought.

The globalization debate is sustained by a continuous stream of indicators, causes and consequences which are interchangeably presented in the globalization debate. So what one author calls an indicator of globalization is a cause or a consequence for others. You have to constantly be aware of what kind of globalization these authors are talking about. Is it an indicator, a cause or a consequence.

What we see in the literature on globalization is that it concerns cross-border capital flows, global spread of neoliberalism, global spread of the network society and global spread of capitalism and modernity, the end of the nation state, the growing role of transnational corporations, and the westernization/americanization of the world.

When talking about the influence of globalization on gender you might have a simple scheme like that the network society is influencing gender relations, or that westernization has its impact on gender. Which is the simple kind of scheme. But it might be much more complicated, because the changes may be the consequences of something else.

Finally I'd like to draw your attention to two sorts of tautologies, the first one is the actual logical definition of globalization, the value-laden definition of globalization. If you think of globalization as something bad, you choose a definition that is negative. You might conclude that globalization is casino-capitalism, which by definition is bad.

Another possible tautology is the reasoning that globalization leads to inequality; inequality in itself is used by capitalism to expand its activities. Capitalism makes use of inequalities, it uses differences in 
wages to move from one country to the next. Globalization leads to inequality, but inequality induces globalization, looking frantically around the world for new investment opportunities.

This exposition is to give background to the discussion on the first statement.

\section{STATEMENT 1}

The growing economic inequalities in the world and the increase of poverty are caused rather by national than by global factors.

Vote: against: majority. In agreement: some.

I would ask the reaction from Thais Corral and Bernard Kuiten.

\section{Thais Corral}

I am from Brazil, for the last sixteen years I've been working in the field of gender, linking gender issues from global to local and from local to global. I came into the debate of globalization through WEDO (12 years ago). At the end of the 1980s with the rise of civil society, a group of women from different countries, that had been active in terms of politics and in terms of communities, thought that the opportunity opened up by the UN on the whole debate on the limits of growth, regarding the questions of the impact on social issues and on development, also on women and the environment was worthwhile. We then thought that the UN wanted to co-operate with civil society. Women went out to bring to the fore so-called women issues. (Rio conference, 1992)

The perspective of sustainable development allowed for this integrated approach. We built a movement, it was a platform of action (women's agenda 21), it was very helpful in having an action agenda which could integrate the various perspectives of the women's movement. Since then I worked for two non profit organizations in 
Brazil, one that dealt with communication and the use of radio to actually have women voices and to empower women in having their own views about the issues - I am a journalist by training.

Back to Brazil we tried to link the global conquests to the local levels in terms of capacity building and national policies. Since 1995 I have been involved in a forum of former heads of States (World Forum 2000). We want to start dialogues between actors to discuss issues that Frans just addressed. A group of women's in the forum assures that the Forum integrates a gender perspective. It should take into account policy actions that could unify different sectors.

My reaction to the statement: I read it several times to see what I feel. It is one of these simple things. My first reaction is that I don't agree with it, but I don't like it. It tries to blame the victims of the process. I heard so many times that the people who are the victims of the system, the poor, the women are responsible for not electing good governments and then for not having not good representatives. The political process always has a historical perspective and the situation is not so simple.

My second reaction has different sides. If I think about Brazil I think the liberalization of the 1990s has a good impact. For years inequalities were caused by the continuity of the reign of oligarchies and subsidies, and this money was withdrawn from social investments. These oligarchies were never preoccupied with changing the unequal basis of society. In that sense the liberalization brought transparency to the ways in which national funds were spent on enhancing national oligarchies. But the crisis in Argentina is the opposite, because it used to have a strong middle class and then liberalization destroyed it.

\section{Bernard Kuiten}

I work at the external relations division of the WTO. That division deals with the WTO and anyone who is outside (NGOs, individuals, parliamentarians, business people, universities etc.). I am for- 
mally the only person in WTO responsible for the relationship between WTO and NGOs. Ten years ago you could suffice with one person, right now it is not realistic any more.

The WTO is an organization based on legal agreements between 144 member countries, the member countries have to implement the rules and if they don't do so they have a problem. They have to follow them, developing countries may apply some more flexibility than developed countries. At the end the secretariat is the one who supports the members in their negotiating efforts, in their analysis, in their research, and the relationship with the outside world.

My background: trade negotiator for the Dutch and for the European Commission. I joined WTO in 1999, three months before the Seattle ministerial conference. We have no expertise whatsoever on the link between trade and gender related questions. It is a subject that never occurred. The members of the WTO through the secretariat which I represent, have never brought this issue up. We do it in the environment area, so the country governments have to make it an important issue.

As to the statement: it would be very easy for me to agree with it. It is a national problem, global issues have nothing to do with it. It is a combination of economic and political factors. Still I only agree with part of the statement. You can't just say there are economic inequalities. You have to look at different group of countries. There have been enormous shifts over the years, whether poverty has increased or decreased. It would have been fairer to look at different regions in the world and particular situations. What do you mean by national factors: policy makers, the business society, geographical factors, or the weather?

\section{Frans Schuurman}

The statement involves either it is corrupt governments or the national elite who are responsible for economic mismanagement. They are the last filter through which global factors are being 
pushed to reach the bottom of a certain country. That is the idea behind the proposition.

I saw some people who voted green, in favour of the statement. Could I invite you to elaborate on your vote?

\section{Fenneke Reysoo}

Globalization as such is an abstraction. I adhere to theories on agency and power relations. I think that globalization can only be perceived through a local perspective (national, regional or at community level). The national level is then a revelator, there the frame is set for social and industrial policies. The government has an important role to play in filtering global issues at the national level. Power relations between actors, the link between the global and the local, are observable where actors meet, be it during UN conferences, WTO negotiations, ministerial meetings or community assemblies.

\section{Bene Madunagu}

National governments are inscribed in history of colonialism and slavery. National governments are imposed.

\section{Frans Schuurman}

Where does the role of colonialism ends? Is colonialism responsible for corrupt governments? Don't you think that this is historical determinism and that it takes away people's agency?

\section{Shahra Razavi}

Going back to the early 1980 s - not to go back to the colonial times - indebted countries had to go to the IMF to ask for loans. Policy conditionalities were attached to the loans. They were forced to adapt policies they would not have adopted themselves. At that juncture governments should not be held accountable for everything that follows, because they were not solely responsible for what happened. There is a consensus that those policies have not been very successful as to the social issues, gender equality etc. 
nor have they been very successful economically. Now if the question is where the responsibility lies, in the particular context of indebted countries that had to take loans and follow certain policies by force - pretty much - the responsibility does not solely lie on national governments. The answer to that question doesn't need to bring us back very far, just in the 1980s when these processes started.

These countries did not get indebted only because of the corruption of their governments. The same happens nowadays. I don't doubt that global issues filter through national settings. In a country with landed oligarchies liberalization of land will be very different than in a context where you have more equality. Of course, globalization always filters through national institutions, national histories, social forces. The statement is problematic because you can't generalize. But at the same time, if inequalities are increasing in $3 / 4$ of the countries of this world, including in those who have very good national institutions, welfare states, relatively equal class structures, there must be an explanation that is not only tied to national factors. There must also something happening that was not happening before, that is happening at a level beyond nation states. You may disagree with that. This calls for an international argument as well.

\section{Isabel Rauber}

We are prisoners of concepts that hide the real world we are witnessing. In the poor countries when we talk of globalization we talk about robbing our countries and about the incapacitation of our opportunities; the break down of our productive systems - and when we talk about production we talk about life; economic structures. The destruction of the productive system leads to the destruction of countries and the existing systems. Globalization, the WTO, the IMF etc. are behind this. We can't discuss this issue without mentioning them. The national-global dichotomy is false. The complicity of our national governments are implied. 


\section{Frans Schuurman}

I am going to ask you after this first round of discussion to vote again for this first proposition. Three people changed their minds, they agreed and now disagree.

\section{STATEMENT 2}

The global economy is based on dominant gender constructions in order to maximize benefits. In other words gender inequalities are beneficial to the global economy.

Vote: Almost all people agree with the statement.

Mascha Madörin

I am a specialist working with NGOs, among others with the Déclaration de Berne, for engendering international trade, engendering budgets in Basle and for churches and sport subventions.

Last year I worked with a small NGO on Swiss Banking in the developing world, a lobby to block the accounts of Mobutu. I am also involved in the link between Swiss Banking and South Africa. A South African coalition has started questioning Swiss Banking cooperation during the apartheid regime.

We are only a few women working on these issues in NGOs, the State and movements. We work on the foreign policy of Switzerland from a gender perspective. Last year we made a press conference on the 7th of March. We made a ten point programme for the State Secretariat for Economic Affairs (SECO). Until now we have managed to get $1 \%$ of our demands integrated. So we have to continue working together. What we request is qualified people in the Swiss delegations and organizations abroad. We ask the government to report on how they take up gender issues in international organizations like WTO, IMF and so on. We ask that they qualify their own people and that they publish what is known on international trade 
from a gender perspective so that everybody knows it and that our parliamentarians and government is knowledgeable about it.

The problem is that there are intellectual restrictions. People think that gender issues is something cultural or something social, but not an economic question. It is very hard to argue at the macro-economic level on gender issues.

I must say that from a methodological perspective I have a problem with such a statement. As a short version for a political position I have no problem. I just want to say that it doesn't convince me very much. I would accept to say global economy is based on dominant gender constructions, but in order to maximize benefits, I am not so sure that this is a simple causality or intention (in order to). In the meantime you would not have such a globalization and such a huge accumulation if there weren't a gendered economy.

The next sentence "in other words" is additional. Gender inequalities are beneficial to the global market elite, which is not the same- I would add an other sentence "therefore it is difficult to change the gender relations in favour of women". I would like to argue a bit more.

This morning when listening to the arguments from a gender perspective, we didn't talk of theoretical perspectives. We don't have a problem of under-research, we have a problem of a lack of theory. A political economy of male dominance, which is not the same as in the 19th century, should be elaborated. I think it has to do with accumulation (I did not hear that word this morning). We always talk about women and micro-credits, we never speak of accumulation and who controls accumulation. A big problem with microcredits is their link with the formal and globalized banking system. Is there a flow of accumulation to this system, how do you organize so that what women have achieved through micro-credits remains in their hands. This is the type of questions we have to ask. We don't have an economic theory on dynamics of accumulation and 
gender, and dynamics of accumulation, globalization and care economy. Many issues have still to be elaborated in economic models and categories.

I have made an analysis of the world market elite. I have looked at the speakers at the world economic forum in Davos. If you look at its composition you have $90 \%$ men, of which $90 \%$ are coming from the USA, Europe and some rare people from Japan. A very low percentage of those world leaders are from the southern continents and they are not women anyway, not from Switzerland, not from Europe, not from the USA. In Switzerland the work without supervision is done by Swiss men (30\%). The other functions are carried out by women or people with foreign passports. So this is one point. I looked at the composition of the women's world march and its participating organizations and organizers. There are $30 \%$ of women from northern countries and all the others from eastern and southern countries. You have two globalizations, the NGO are differently globalized than the world market elites. We have to distinguish and talk about these two forms of globalization.

\section{Frans Schuurman}

It is good that you mentioned that we need new economic theories. Just to mention a figure, 25 to $30 \%$ of international trade takes place within the same multinational. Which means that the mother is trading with its own daughter, that it eludes and erodes standard economic theories to understand what is going on there. We are in entire need of new economic theories.

\section{Mascha Madörin}

Coming back to the first discussion on international and national factors, we must look at the Swiss Banking system and what the foreign companies are doing with transfer pricing. If I see how much money we have for being democratic, and how much of this money should be in Africa, Asia, Latin America or eastern countries, then as a Swiss I don't dare speak of corrupt elites in southern countries. 


\section{Naoko Otobe}

I work with the ILO, which is a rights based organization. The ILO has 183 international labour conventions regarding gender equality, freedom of association, collective bargaining, occupational health and safety, etc. The ILO promotes various labour standards at the international level. Within the UN system the ILO is rather unique, as it is tripartite and its decision makers are not only governments, but also employers' and workers' organizations. So these issues are debated in the tripartite structure. The ILO has four strategic objectives: 1) promotion of principles and rights at work, 2) promotion of employment, both for women and men, 3) social protection and social security systems, 4) promotion of social dialogue.

Across the board the ILO is now trying to mainstream gender in all its activities, its own structure, as well as the staff. The ILO has a Decent Work agenda. Decent Work is work undertaken in conditions of freedom, equity, security and human dignity. I have been working with the ILO for more than ten years now, especially to address the gender dimensions of the impact of macro-economic policies on labour and employment, including of Structural Adjustment Programmes in both Asian and African countries, and more recently, I have also been involved in research on the impact of the economic crisis in the Philippines and other Asian countries.

I make a response to the statement. It is very interesting that the large majority voted "yes, we agree". I wish that I could say I agree in a complete form, but my reaction is that I am not sure whether I can fully agree with the statement. It says that "it is based on dominant gender constructions", but it is probably due to the social structures that exist in the interaction with economic forces, the social disadvantage of women or some other social groups tends to manifest also the economic sphere, as the market outcomes. Gender construction is more of an influencing factor on the outcome of the market systems. It is not the same as to say that "it is based on a gender construction" per se. Especially, as Mascha said, the state- 
ment says "in order to maximize benefits, current economic systems really try to "exploit women" or some other groups. Furthermore, it is not only women who are at disadvantage; it could be others groups, minority groups, or young people. The market works with the demand and supply mechanism and that is really gender blind, or socially blind. What we are looking for here, as a counter-measure of laissez-faire market forces, is to moderate the market processes, and of course, one of the measures we can implement at the national level is certainly to promote equal rights. If employers and workers are more aware of equal rights, and if that can be translated into better employment opportunities and improved working conditions equally for women and men, of course, all parties will win, and the wages will be more gender-equal. This might be utopia, but to me it seems exaggerated to say "in order to maximize benefits" as such. Although it is true that women are disadvantaged because of their lower levels of education, illiteracy, skills, market access. And this is the reason why we need to implement various measures to promote equal rights, through a rights-based approach to development, which then could moderate the market processes.

\section{Frans Schuurman}

Thank you very much. The audience is asked to react.

\section{Genoveva Tisheva}

What does the very fact that the WB and WTO are not working with gender, the reality of existing stereotypes and already segregated labour mean. Agents of globalization don't take gender into consideration, so what does it mean actually. It means that they condone what has already been achieved in some countries, or like in Bulgaria they agree to condone the regulation of labour standards.

\section{Bernard Kuiten}

Please don't mix up WTO, IMF and WB. WTO is not confronted with gender related issues in the area of legal rules that we deal with. They are not brought up. People talk about general rules of how governments can behave in the international trade relations, 
they don't come up with particular issues such as in WB or IMF projects. In a negotiation on service liberalization a country may say "we would like to keep this sector from any competition of the outside, because of a gender argument". That is fairly possible. But you will not find that reference in any of the legally binding documents of WTO. This is an example of a gender motivation position in trade negotiation, but it is very difficult to find a theoretical argument to bring together a gender argument into the legal context of the WTO. This is the debate we have with several NGOs. If you come up with a specific theoretical framework for us or for the governments there may be a leeway, but so far these legal frameworks do not exist. Thanks.

\section{Ewa Charkiewicz}

I want to say something about the differences between $\mathrm{WB}$, IMF and WTO. They have signed coherence agreements in Marrakech when WTO was formally established. The developing countries, especially in their strategies of poverty reduction, work with an integrated framework, which put the trade liberalization as the key factor in reducing poverty. There is a new form of colonialism which comes from these coherence agreements and from integrated frameworks and emphasizing differences that do not do justice to realities. The indebted countries have very little room to maneuver. The other thing is the statement itself, and the dominant gender constructions. We have spoken a lot of women in this conference but we very rarely mention men. Masculinities have also been restructured by globalization. On the one hand, we have the Davos man and on the other the El-Qaida man. The agency that is expressed by El-Qaida man is close to masculinity construction experiences by men who lost a job, who have to take feminized jobs which are underpaid, by men in Russia who do not reach their retirement age, and by men who experience loss of a sense of identity. There is a huge social cost of globalization to men and to the restructuring of masculinities, but there is also the emergence of new dominant masculinities, such as the Davos man construction. Masculine agency in the context of globalization tries to maximize 
profits and to speed up the whole process of production and consumption when the costs of social reproduction, or social and ecological cost of globalization, are to women. When they are and not shared, when gender relations remain hierarchical, we can not talk about partnerships new dominant masculinities as partnerships, be they El-Qaida or the Davos man. We need partnerships to improve the position of women, and gender relations so that they can become partnerships.

Vote: One or two people changed from green to red.

\section{STATEMENT 3}

Open markets and free trade while appearing to offer opportuni ties to some women, actually marginalize people from decisions that impact on their lives.

Vote: The entire audience is in favour.

\section{Jean François Giovannini}

Until July 2001 I was the vice-director of the Swiss Development Cooperation. I have participated in international politics. I was member of the Swiss delegations at the international UN conferences in Rio, Cairo and Copenhagen. We have always tried to integrate the proposals put to the fore by feminist organizations. On a systematic basis we have been working with organizations that deal with gender issues. SDC has been taking along gender issues for more than 20 years now. Our policies develop in line with international policy making on these issues. Initially we only addressed women issues, later we have been involved in making more thorough gender analyses. Our gender desk is excellent. The implementation, however, meets obstacles. First of all, we have a problem of expertise and human resources. Every one agrees on the principle, but reality is more complex. Furthermore, we are confronted with resistances in the countries we work with. The results are still mitigated. 
In terms of globalization I would like to make a general remark. It is very difficult to use general language for such a complex reality. I agree more or less with what is being said here. But we need to go more in detail. I think we don't have too much of a choice, globalization is a fact. There are very few countries that really have an option in the matter. Some countries are outside globalization, some countries have made a choice or the choice was imposed on them (Iraq, North Korea, Cuba, Myanmar, Afghanistan). Only very big countries, such as the USA or China, do have the possibility to limit their integration in the global system. The USA could quit the global system. Their foreign trade does not represent a big part of their GNP, they are dependent on the outside just for petrol. For a small country like Switzerland, it is simply not a choice. We can't survive on our own.

Rather than saying in favour or against globalization, what interests us is the question of how we can best profit from it. How can we create a social system for those who are most marginalized? There have been a lot of promises made, how can we help the poorest countries, the EU has decided to open its borders to less well off countries.

In Doha, we heard many complaints from certain countries, there were suggestions to improve the situation. In the last few years we have seen the contrary. Liberalization has been promoted, but there has been a lot of resistance to it at the same time in the northern countries, which have opened their borders less than the southern countries. Switzerland needs to be more conscious in its efforts, but I'm not sure that it can do it. The political reality is that NGOs are crying out for a more equal system, and at the same time there are important economic interests and political power involved; this leads to contradictions. The Swiss agriculture for example is not ready to open its borders to the outside.

It is the responsibility of organizations such as the SDC, and of people like my self, to reinforce women's ability to dialogue, to sup- 
port feminist organizations and civil society organizations and to elaborate political systems that are more democratic. ILO has set international labour standards, we need to support the fight against child labour, the violation of social standards, we need to support environmental and economic co-operation on an international level. This could have a positive effect on other countries and on marginalized groups, including women. We can guide these changes in a positive manner at national level.

\section{Bernard Kuiten}

I find it hard to see how open markets or free trade marginalize people from decision making. I would reverse the argument: to what extent are people marginalized or not involved in decision making on trade liberalization. That is a fair question, and that goes for northern countries and southern countries. A problem is that open markets and trade liberalization have always been taken for granted, for 40 or 50 years certainly under the GAT T. More recently has there been a stronger debate on whether pure free market neo-liberalism is the best way to approach economic progress, sustainable development etc. The next question would be to what extent are people involved in decision-making by governments when it comes to defining trade policy. Then you come to discussing democracy. At the level of the WTO we have not much of a choice then to accept the situation as it stands, the positions taken by the members. Their negotiations when they are together follow a democratic process. It is probably not the case in every individual country, and there are elites who have dominant positions. WTO has to start with the idea that governments are the outcome of democratic processes. I disagree with the statement as it stands right now. I would reverse it to: when are people involved in decision-making when it comes to trade liberalization, trade policy and eventually the way the negotiations are being conducted within WTO? 


\section{Thais Corral}

These big organizations (WTO, etc.) have a very ambivalent position. They have a lot of influence on what countries do. Failures are the responsibility of the nation states. They have the tools to push for their main concerns. I think this is ambiguous and controversial. The WB for years has implemented projects for which they organized public hearings. These assessments were completely vague, real problems were avoided- It was just a matter to go through a bureaucratic process. It was not until recently, when much more people - women and men - and communities are organized to be able to be vocal and to understand the processes that they could have more influence, and now it is not done. There is a responsibility to involve people into the decision-making processes. This implies commitment. The big organizations have their responsibilities in this, because in many countries there is not a strong civil society, so the big organization should be aware of the pitfalls of the process.

Furthermore, among the 144 WTO members, only 12 representatives are women. This is not acceptable anymore in a world organization, after all the international conferences where we have been asking for gender equality. If countries don't send them, you have to push them as you push for other things.

\section{Christine Verschuur}

I doubt the democratic functioning of WTO, because there is a lack of women present at these negotiations.

Second, we need to examine what kind of globalization we need. Unesco goes for globalization with a human face. We need rules in order to "control" globalization. Opening up the markets is good for the south but not for the north. Everybody is equal, but some are some equal than others. The rules of globalization should apply for everybody.

Third, many themes are not mentioned. Economic theory is very limited. Feminist economists have made interesting contribution 
(care economy, social reproduction). The States are not any longer taking up these issues. Personally I am interested in the progress of these issues.

\section{Silvia de Zordo}

At local level, women have opportunities, they are more mobile, leave their villages and discover new horizons. A research was conducted on immigrant women in Italy, coming from Eastern Europe or from Latin America. They were young, left everything behind, it was a choice they made. Their choice was rather forced, they had no alternative. They abandoned family and children, this resulted in problems. What did these women do? The work of social reproduction and the state did not provide social services. The women have no rights, they are foreign, they are confronted to violence. What sort of opportunities are we talking about here?

Vote: Nobody changed their minds.

Frans Schuurman

Let now step over to practice. What is to be done?

\section{STATEMENT 4}

With today's form of globalization there is no role any more for international development co-operation.

Vote: The majority disagrees with the statement.

\section{Jean François Giovannini}

As a representative of a development co-operation agency, I have always thought that development co-operation, especially bilateral co-operation, went the wrong direction. It is not a good system. First we should realize an equitable international trade system allowing every one to honestly earn a livelihood. Markets should be 
really open and subsidies to the agricultural sector abolished. And besides that we need a UN system for particular activities, such as Unesco for training activities. Unfortunately, the political reality is that bilateral co-operation gets substantive political support in the North, although this is not the case anymore in the USA. It is much more difficult to get political support for compromises in the field of international trade.

NGOs have to show the contradictions between what is and what should be and raise public awareness on the problem of a system where all countries can take advantage of the global system.

\section{Mascha Madörin}

I agree with what is being said. We have to distinguish between local development projects and general economic policies at the international level. With respect to development projects which are a sort of empowerment work or social work. I think that as long as people are poor and so many are poor, I am not economically able to organize their living. It is different from making a barbaric economic policy. The word international development co-operation is false, it is international development aid. We have to come to a new international policy.

\section{Frans Schuurman}

International developement co-operation was either bilateral or directed at civil society. In the first instance, one of the essences of globalization is the end of the Nation State. National governments have less and less power to decide on what happens on their own territory. So it would be unwise and inefficient to take them as partners in development co-operation. To come up with projects for civil society gets the character of emergency aid, than of a structural way to helping people forward. What can be the role of international co-operation? 
Bene Madunagu

I want to say that it is not only the present form of globalization that should be the basis of international development co-operation. But that there should be co-operation between governments based on transparency, democracy and with people wellbeing as defined by and understood by people. It doesn't have to take the form that it has today.

\section{Wendy Harcourt}

I think behind the statement is the fear that many individuals and organizations which know what the problems are: poverty, gender inequality, ... They realize that they are powerless now to do anything about it. The UN system and the way it is set up, the UN agencies are no longer the actors in the international system. WTO, IMF, WB and the hidden powers are the agents now. International co-operation was set up 40 years ago in a completely different world. In today's world, which institutions are going to bring what we all want: equality, social justice, ... not only between nations but also within nations. Is it really going to work the way it is set up now? On top of that the financing for development costs a lot but we don't have the frameworks to get that money forward. It is clear that the real people who make the decisions are powerless also. The system doesn't work anymore, there are people who dedicated their whole lives to do it, we need to work with it. This is the hard question for me, I don't have the answer. Is Porto Alegre the answer? I don't think so, but that is what we have to debate. Most of all we keep away from gender in all this. Is Porto Alegre going to put forward gender equality? There is the Davos man, but a lot of the same people from an other political viewpoint ignore gender as well in the Porto Alegre camp.

\section{Thais Corral}

I want to build on what Wendy just said. We keep repeating a lotWhat is the effectiveness of all the co-operation that has been going on? Much money is being swallowed in intermediary levels and did not come to the peoples in need. 
Porto Alegre is an expression of civil society, with contradictory aims. Gender should be a transversal theme this year. It gives a measure of how mondialization (not globalization) has worked out. A lot of networking is going to happen. People who are coming should debate and not only put forward one perspective.

\section{Mascha Madörin}

I am working in international networks and international economic politics. If I look at Attac, if I look at the movements that have come up I have a total déjà vu experience. It is like in the 1970s as to theoretical perspectives. It represents how men imagine feminists imagine things. Even in the anti-globalist movement it is the same. Theoretically we know much more than has been expressed until now. We reinvent the wheel every time, we discuss like in the 1970s and I am really fed up to do so.

\section{Bernard Kuiten}

WTO has no project thus no donor money going into that. In the recent 3 years, and certainly now after Doha a lot of money has gone into technical assistance and capacity building. Mainly on the request of developing countries, it comes from development ministries of the developed countries who generally are the suspects. There is a focus of these ministries to put money in WTO. Whether this is good or bad is not relevant here, if WTO is considered a bad thing, we then have to wonder what is going on with development co-operation. It is still minority money, compared to the overall budget.

\section{Naoke Otobe}

The ILO is now trying to promote its Declaration on Fundamental Principles and Rights at Work (Fundamental right conventions include those on gender equality, elimination of child labour, collective bargaining, freedom of association and forced labour). The Social Summit put to the fore these conventions as fundamental, and it was not the ILO forum which decided they were fundamental. The International-Focused Programme on Declaration is putting 
money in the promotion of the principles of the Conventions through technical co-operation projects and programmes, in the areas of gender equality, forced labour and social dialogue. The ILO also has an International Programme on the Elimination of Child Labour. The ILO implements projects through a rights-based approach, and we have to promote rights in the context of development. For example, the ILO aims at a better implementation of these fundamental principles and rights through projects implemented in Export Processing Zones (industrial areas). It is yet to be seen, however, what impact these projects will have on workers.

I disagree with the statement. We can continue to take action to promote gender equality in the world of work, through a rightsbased approach to development.

\section{Frans Schuurman}

The existence of undemocratic regimes would be favourable for development aid. After the change of regimes in Argentina and Chile they cut off development aid from Europe. The lack of democracy is a raison d'être for development co-operation.

Vote: one person changed her opinion.

\section{STATEMENT 5}

Gender equality and sustainable development should no longer be limited to the field of gender and development co-operation but extended to international financial institutions and international political relations (WB, IMF, WTO).

Votes: everybody agrees.

\section{Mascha Madörin}

In Switzerland we had a big campaign when Switzerland joined the IMF and the WB. We had a successful campaign around the 
enforcement of development law to WB and IMF. Yes, OK we report on the politics of the WB but not of the IMF. They think that gender is a question of social relationships and local questions. It is not a question of macro-economic policy. It is generally believed that finance and banking have nothing to do with genderWe have to work on this. This level of theory is little developed. We have to engender universities, especially the teaching of economics in Swiss universities.

\section{Frans Schuurman}

There is a huge gap between development practitioners and universities.

Leading social scientists are co-opted by international organizations (There are many social scientists now working within the WB on social capital).

\section{Mascha Madörin}

There is another gap between development co-operation and foreign policy in Switzerland, and also between economists and social scientists. Development economy is not considered economy. Feminist economy is a top sport, only 10 per cent of economists are involved. Too few economists take it seriously, let alone integrate it in their work. These separations are terrible.

\section{Jean François Giovannini}

I would like to introduce the image of corrida. International organizations are a little bit like the red flag used to cheat the bull. The real decision-makers are not the international organizations, but the governments. And some governments have more power in these organizations than others. It is convenient for them to put the blame on the World Bank or the IMF. The real responsible people are within the US congress. That's the locus for resistance to change and that is why the lobby for change should concentrate on the US congress. If the US congress took stronger positions, the international organizations would easily change. We 
should not continue to blame these institutions-because they do not exist on their own. We have to look at where the real power lies, and this is in Washington, in the US congress, but not in the World Bank.

\section{Bernard Kuiten}

It is not happening. No gender debate comes into the WTO. due to a lack of theories. We are a legal institution. How can you feed into the legal rules of the WTO a reflection of certain gender aspects? The same goes for the human rights debate. Trade and human rights is an issue that came up two years ago through NGOs. How do you see human rights reflected in legally binding rules of WTO? Like the preamble, yes we can write we should take into account sustainable development or human rights, that doesn't bind anyone. Is it feasible to include it into the rules. We are not equipped to do so, we have no experience. The Doha looked for the first time at trade and environment. It took 7 years to negociate the agreements. Greenpeace changed their strategy from being totally opposed to attracting attention from governments, they focused on substance. Many developing countries oppose it, they don't want environmental questions, because they can't live up to international standards. These are long processes, you have to link the theory to legal processes when it comes to WTO.

\section{Frans Schuurman}

I doubt if it is a matter of theory or of political will.

\section{Silvia Federici}

I have heard the argument so many times that the inequitable situation and trade relations are there because the south wants it: "We can not abolish child labour, because it is a real need of countries (India, Pakistan)". The IMF is bending to these needs. This is not an appropriate argument.

What is the process? How does a country decide not to abolish child labour. Why do they depend on that? We have to study that. 
There are responsible people and organizations. They use to say that their hands are tied. It is trap.

\section{Chrystel Ferret}

There are a lot of frameworks from feminists economists. But these tools are not used. It is a matter of political will. Gender budget was considered rubbish within Swiss Development Co-operation, but it is due to ignorance. A lot has to be done at national level. As citizens we can do it. At the international level we also have to lobby. There are frameworks for gender budgets. We have to lobby our male colleagues. It has to be mainstreamed in the institutions. If the states don't make an effort WTO will not change, it is a political issue.

\section{Fenneke Reysoo}

Let me say a few words to close the debate. A red threat that runs through our discussions of the five statements is that the issue of global economy and its impact on social development and gender is very huge. At several points in time, we were urged to specify about which processes we were talking. Was it about indicators, causes or consequences? Furthermore, there was an appeal to take into account historical, political and cultural contexts when analysing the impact of open markets and free trade on the position and status of underprivileged groups. The growth dilemma popped up at several moments. Although we have not questioned the idea of (a certain) economic growth, on the field we observe various negative consequences of national and international market forces which are blind to social and gender issues. The participants of the round table have warmheartedly shared their points of view and the varying visions have led to interesting exchanges. We sincerely hope that the debate has contributed to sharpen your own ideas. We wish you good continuation in your work and research and thank you for your participation. 


\title{
Gender and ECONOMic Globalization
}

\author{
REFLECTIONS ON THE IUÉd GENEVA COLlOQUiUM
}

25-26 JANUARY $2002^{1}$

\section{Wendy Harcourt}

The following article draws on the discussion of the iued Colloquium on Gender and Economic Globalization. The Colloquium aimed to draw out the impact of economic globalization on gender relations, with a particular focus on poor women in developing countries.

\section{GLOBALIZATION - FOR OR AGAINST WOMEN?}

In order to look at the impact of economic globalization on gender relations, and more particularly on poor women's lives, we are confronted with a complex set of interlinked dynamics. Inequitable

1 A Dutch version of this article has been published in Wendy Harcourt \& Femke Molenaar, 2002, “Gevaren én kansen voor vrouwen. Vrouwenallianties op mondiale schaal." in: NCDO jaarboek 2001-2002. Amsterdam: National Committee for international co-operation and sustainable development, pp. 66-73. 
gender relations are integrated into economic globalization and at the same time globalization builds on such inequalities. With globalization, lives are shifting as the different economic, social and cultural institutions informing gender relations change.

But are these changes positive or negative?

The popular myth is that economic globalization has introduced greater openness to trade and capital mobility in a positive way for poor women in the South. However, the true picture is much more fragmented and differentiated for the many millions of poor women living in the South. In reality, only 13 developing countries are engaged fully in economic globalization, and really only in relation to the manufacturing sector.

When the effects on developing countries are studied, today's economic globalization has led not so much to economic growth but rather to a mobility of global capital. If we take the different sorts of work in which poor women are engaged - manufacturing and industrial, rural, informal sector, domestic work for other families, caring for their own family and communities - economic globalization has rarely improved women's situation. If looked at over time, the 1980s saw a major opening up of new types of employment where many young women were able to enter into new types of jobs. This situation had already changed by the 1990s with a defeminisation of labour, particularly in the high-tech sector. The slowing down of employment expansion led to men taking over the new jobs held by women.

In the rural areas growing insecurity and environment degradation, changing population with migration and AIDS and other diseases have preyed even more on poor women than men as they are economically and socially more vulnerable.

In the informal sector where the vast majority of poor women work, economic globalization has made little impact on conditions, 
income, or official recogniton. And alongside all of the paid outwork in the home economic activities - women's core role in the care economy (her reproductive work looking after home, families, communities) - continues largely outside traditional economic policy and analysis. Indeed, in the name of globalization and economic growth many structures that supported women's caring role (public funding for health, education, community services etc.) have been privatised in the last years, grossly undermining the quality of life for many poor women and their families.

Therefore, in reality, many poor women fall outside the benefits of economic globalistion and those that are engaged in it are rarely secure. In addition, there are also the unheard voices of the women that are so globalised, the mobile women (migrants, sex workers, domestic workers), that are moving around the globe quite outside national or international controls.

Although it is useful to have some general idea of how economic globalization and gender interrelate for poor women, it is almost impossible to generalize. For a more nuanced picture we need to understand which women, which situation, which historical moment. Some women are benefitting, some women are not. And, some women might see themselves as benefitting even if others do not perceive it that way. For example sex workers might prefer to be in Europe working and earning money to send back home instead of being caught in a trap of poverty and disease with no access to resources.

\section{The AREAS INBETWEEN}

Even if the picture painted is largely one of deprivation and difficulty, this picture is not so different from earlier forms of global economic activity during colonial and the post War economic development period. Traditional economic power structures feed on deeply embedded gender inequalities with poor women at the bot- 
tom. But the above general sketch does not do justice to many poor women's struggles and achievements to survive the economic and social transformations going on around them. What is important to note is that there are some new things happening. Today's economic globalization is also creating windows of opportunity for change, even if it is not automatically for the good. To understand what is new we need to go beyond traditional economic studies and policy assessments and assumptions.

What is needed is an inbetween understanding of globalization and women's different involvement and the diverse implications that has for gender relations. Women's roles as workers, nurturers and carers are changing and so are the opportunities for them to contribute to shaping political, social and economic reality as intellectuals, activists and policy makers who are producing new knowledge about economic globalization, new ways of networking and understanding how the world is working.

There are possibilities for poor women, working collectively or with other women help to provide support and resources, to change traditional social, cultural and economically oppressive situations. Though it can be, in the short term, at a great cost of women's lives, losing their communities and their families, losing love and care, living risky lives fraught with uncertainty, it is important to see that women are agents not victims of economic globalization, resisting, shaping and negotiating the impact of economic globalization on their lives.

\section{How ARe Women Moving ForWard?}

In a positive way, the new information and communication technologies, that have accompanied today's form of economic globalization, allow a vast number of politized women, often working in civil society groups, to reach out to poor women and to strategize together in unprecedented ways. There is a strong sense of solidar- 
ity, among women "on the picket lines" who are moving and changing globalization in very difficult situations (in times of economic crisis, social breakdown and change) and bringing with their interactions vision and energy to keep each other going.

In less marginal areas, but certainly in support of poor women, women are bringing gender issues in the mainstream processes of the UN conferences into economic debates, and into trade debates. Women's caucusing in UN meetings has produced a number of strategically critical women and economic justice networks, and alliance building among regions producing different sorts of knowledge and strategies.

Even if making their voices heard, in terms of development institutions there is a long way to go for gender policy to be accepted and for the problems economic globalization is creating to be looked at squarely. There is concern that the World Bank is taking up so many issues that they are knocking out all the other UN agencies working on gender, in a process that coopts rather than consolidates a gender position. The IMF is not gender sensitive, it is questionable whether the work even of UNIFEM on gender budgeting is acknowledged by the IMF and even more doubtful if WTO has understood what is gender or how to incorporate it into a legal framework.

\section{STRATEGIC DiRECTIONS}

When analysing how to improve the lack of voice or knowledge of the impact of economic globalisation on poor women in the mainstream debate, the issue is not only about knowledge it is also about power. How do we create a political change that allows poor women's concerns to be heard and acted upon among people (largely northern institutions with men making the economic decisions) with power what is the so-called win-win situation for them? If we are to address this issue we need much better analysis of how 
those power institutions are working, and clear factual and convincing analysis of the complex situation of economic globalisation for gender relations. Here it is important to be asking the right questions. Are we trapped in the so-called language traditional academic readings of economic globalization that ignores gender? How do we close the knowledge gap among the scientists and economists and gender experts? And how do we work within or with powerful economic development and academic institutions without becoming co-opted?

Many feminist economists are courageously pushing academic frontiers in economic analysis, but they rarely reach the important decision making places. The question is how to connect the various groups, knowing and being able to detail well the impact of economic globalisation on poor women and then getting their voices heard in the right places to bring about change.

We have to build on the knowledge and analysis of women working in the South and feminist economists and others who are collecting their stories and analysing and assessing. We have to close the gaps between the realities of poor women in the South and what macroeconomic institutions state are the realities.

We have had a decade of UN conferences, and now, for the first time, we have a World Summit on Sustainable Development in Johannesburg in August and September 2002. Is this one place where women's voices can be heard? Where the knowledge gathered can inform high level economic and development policy debates? Johannesburg could be an event that poor women's voices, needs, visions and hopes for the future are heard. The Women's Agenda 2015 sets an important list of priorities built on 10 years of assessing poor women's struggles with economic globalization.

The challenge is to examine honestly the failures of international institutions to formulate and evaluate financial and trade policies from a gender perspective. It is also to lobby for governments to 
address working conditions in the informal sector, and wage inequities in the formal sector, or to integrate women's unpaid work into national accounting systems. This is one window of opportunity we cannot fail to loose. 


\section{BULGARIAN GENDER RESEARCH FOUNDATION (BGRF)}

The Bulgarian Gender Research Foundation was founded in June 1998 in Sofia by women committed to work in the field of women's rights and all of them with previous experience in advocacy, education, monitoring violations of human rights, lobbying for legislative changes, preparing publications, networking. The group consists of lawyers, university professors and women's rights activists. The group was formed because all the founders strongly felt that there was a need for specific research, education and advocacy in the area of women's rights.

The group mainly aims at promoting and facilitating the achievement of a gender balanced society in Bulgaria based on equal representation of women and men; disseminating information and raising the awareness about women's rights and gender issues in Bulgaria; advocating compliance with the Universal and European standards in the field of Human Rights and the universally recognized values of democracy.

The main issues we work on are: violence against women with specific focus on domestic violence and sexual harassment; social-economic rights of women during the transition; and gender research and advocacy aimed at promoting women's political participation. Gender is considered in the context of social justice. These are all 
new issues in Bulgaria, difficult to work on and controversial in our society.

The Bulgarian Gender Research Foundation is a national NGO. Although established and registered in Sofia, the group works in network with local NGOs, groups and individuals interested in our work and needing information and assistance in our field of activity. We have well-established links with such groups from the main cities of Bulgaria - Sofia, Plovdiv, Varna, Bourgas, etc. Our NGO is also part of international human rights and women's networks as the NEWW, CCC (Clean Clothes Campaign), Social Watch, WIDE, WICEJ, KARAT coalition, etc.

\section{Activities AND Programs (SELECted)}

- The BGFR participated as a Bulgarian partner in the Project "Elimination of violence against women through research and education" with Minnesota Advocates for Human Rights.

- Sept.1998- March 1999: the BGRF coordinated the review of the follow-up of all major UN HR Conferences undertaken by UNDP in Bulgaria.

- June 98-September 99: the BGRF carried out a joint research Project with WLDI including a sociological survey and a legal research "Women's Empowerment in the Privatization Process" and publication of a final report (130 pages) on the impact of the restructuring processes on women's social-economic rights in Bulgaria.

- In 1999 the BGRF worked on an advocacy campaign promoting the concept of the right to free legal protection of women in court in cases of domestic violence. This project was aimed at at raising the awareness and understanding of the Bulgarian society on the problems of violation of women's human rights through education of women's groups, media, police, lawyers. Booklets 
with guidelines for the representatives of social services, police and health care professionals were produced.

- In October 1999 the BGRF was involved in the preparation of an Alternative Report to the Third Periodic Report of Bulgaria on the implementation of the International Covenant on Economic, Social, and Cultural Rights, and 2 representatives of the organization participated in the 21st session of the CESCR in November in Geneva.

- BGRF was actively involved in the Beijing +5 process and representatives of the organization participated to the regional meeting in Geneva (January 2000), the PrepCom in March 2000 and the UNGASS in June 2000. BGRF presented an Alternative report to the CONGO as well.

- May-December 2000 : the BGRF conducted a research project "Equal rights and equal opportunities of women in political life in Bulgaria" - a sociological and legal survey, conducted with the support of UNDP-Sofia and the Gender Task Force of the Stability Pact. A research report was published in Bulgarian and in English.

- Since May 2000 : the BGRF carried out the project "Advanced strategies for combating violence against women - A pilot free legal aid and legal clinics scheme".

- Since February 2001 : the BGRF is the regional coordinator of the preparation of a monitoring CEDAW report for Bulgaria, Croatia, Macedonia, Albania, Serbia, Montenegro, $\mathrm{BiH}$.

- The BGRF prepared the national reports for the 2000, 2001 and 2002 editions of the Social Watch report.

- Since April 2001 : creation of the first CCC campaign in Eastern Europe and implementation of the research project on social standards in the garment industry in Bulgaria. 


\section{Contact Persons and AdDress}

Genoveva Tisheva, Executive director

$\mathrm{D}^{\mathrm{r}}$ Irina Moulechkova, Head of the Board of Directors

Plamenka Markova, Coordinator Social-economic issues

Jivka Marinova, Publishing program manager

12, Liuben Karavelov St., Sofia 1142, Bulgaria

Mail address - P.O.Box 938 Sofia - 1000, Bulgaria

Tel./Fax: 003592 989-7308 /003592 980-8801

E-mail address: bgrf_jiv@inet.bg 